


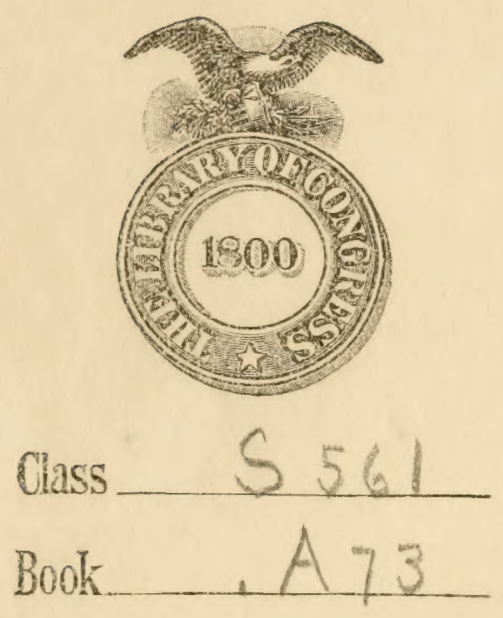

Copyight No

COPXRIGHT DEPOSK 






FARM MANAGEMENT 


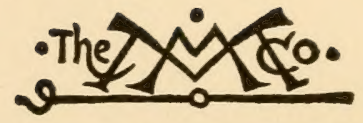

THE MACMILLAN COMPANY

NEW YORK - BOSTON - CHICAGO - DALLA

ATLANTA - SAN FRANCISCO

MACMILLAN \& CO., Limited

LONDON - BOMBAY - CALCUTTA

MELBOURNE

THE MACMILLAN CO. OF CANADA, LTD. TORONTO 



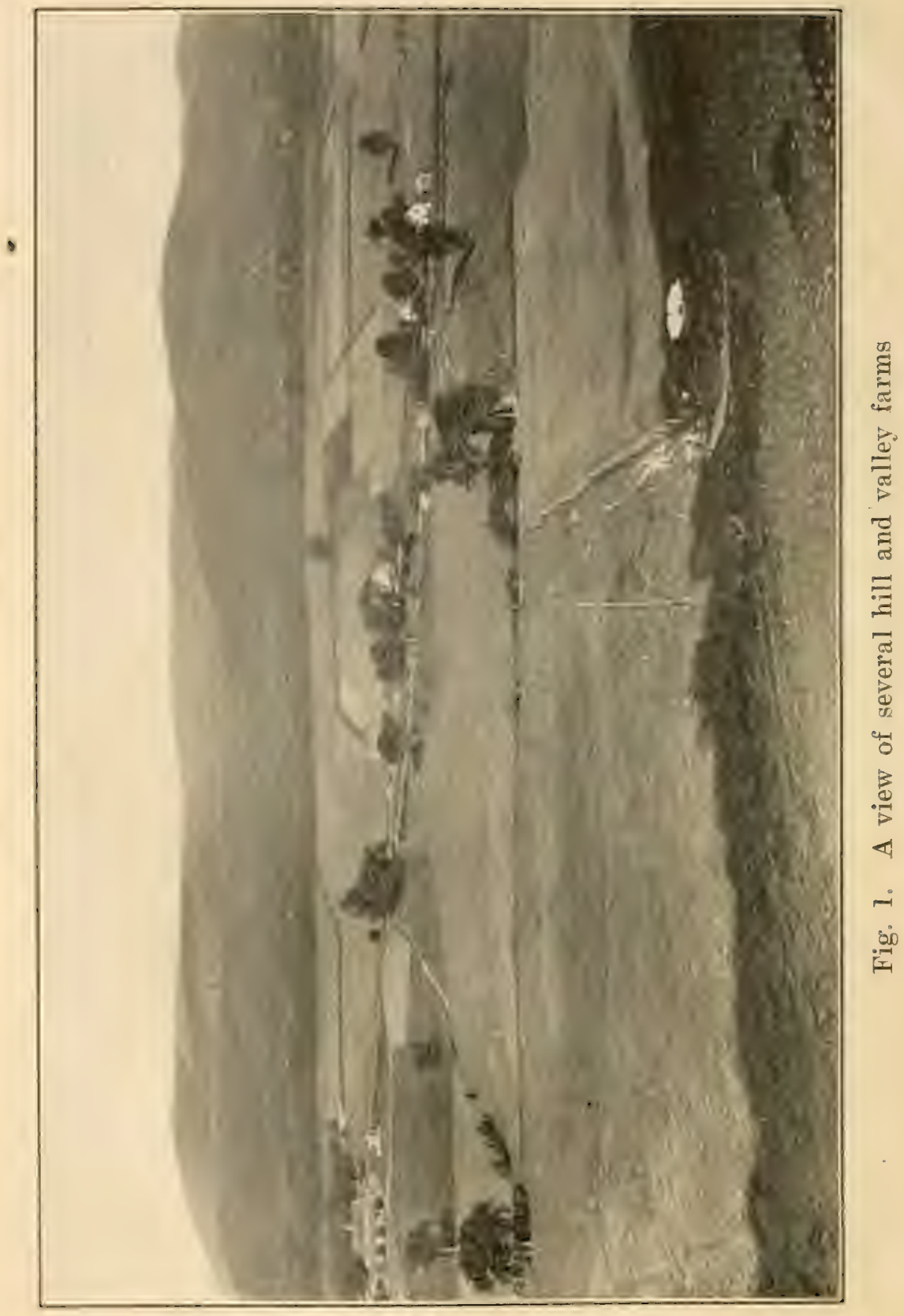




\section{FARM MANAGEMENT}

BY

JACOB HIRAM ARNOLD, A.B.

Agriculturist in the Office of Farm Management,

U. S. Department of Agriculture

\section{田ew 想ork \\ THE MACMILLAN COMPANY \\ 1919 \\ $4 l l$ rights reserved}


COPYRIGHT, 1919

BY THE MACMILLAN COMPANY

Set up and electrotyped. Published July, 1919.

$0 \vdots$

(C)CH. $5: 30: 360$

JUL 251919 


\section{NOTE}

It has been only in recent years that much attention has been given to the study of Farm Management. However, from the standpoint of practical farming, it is probably the most important phase of agricultural study. The subject being new, it is somewhat difficult to present in as logical and clear a manner as may be done when presenting other phases of agricultural science to which more attention has been given.

The author has tried to avoid being technical, the principal aim being to interest the reader in the point of view of Farm Management rather than to give specific technical information.

The figures used in the tables in the book represent pre-war conditions. Since these figures are used to illustrate general principles rather than to give specific information, they are believed to be less misleading than figures obtained under the abnormal conditions of the recent Great War. 



\section{CONTENTS}

CHAPTER

I What a FARM Is . • . • • • . 3

II TYPES OF FARMS . . • • • • • 25

III Advantages Gained by Situation • • 42

IV Advantages Secured by Control • 74

V Farm Crop Problems . • • • • 98

VI Problems of Livestock • • • • . 123

VII FARM Organisation . • . • • . 149

Vili How to Measure the Efficiency of

Farm Organisation . • . • • . 176

iX Business Methods and Principles ApPLIED to FARMing . . . . • . . 192

X Farm Administration . . . . . . 210

XI The State and the Farm . . . . . 233 



\section{ILLUSTRATIONS}

A View of Several Hill and Valley Farms . . Frontispiece FACING PAGE

A Favourable Situation for Field Crops on a Mountain Side below Limestone Clifis . . . . . . . . 54

Terracing in some Situations is the Best Means of Controlling Soil Erosion

Cattle Feeding may be a I.Yeans of Ctilising Time Profitably, Marketing Corn to Advantage and of Maintaining Fertility . . . . . . . . . . . . . 90

The Cotton Crop Requires Much Hand Work and Employs Family Labour to Advantage . . . . . . 106

Chart Showing about the Amount of Labour Required on Crops and the Seasons when it is Usually done,for Western Kentucky and Tennessee . . . . . 111

A Favourable Orchard Site in the Appalachian Mountains 116

One Way to Waste Farm Resources . . . . . . . 136

Chart Showing the Distribution of Labour on a One-man Three-horse Farm . . . . . . . . . . 154

The County Agęnt Demonstrating to a Group of Farmers the Right Way to Prune an Apple Tree . . . . 236 



\section{FARM MANAGEMENT}

\section{CHAPTER I \\ WHAT A FARM IS}

THE common idea of a farm is that of a piece of land devoted to some agricultural use. We think of a farm mostly in terms of area of land, quality of soil, assorted crops and domestic animals, having, generally speaking, little conception of the really vital thing about it, namely, the adaptation, selection and adjustment of these factors which result in farm organisation. Much is heard about small farms, medium-sized farms, and large farms, yet the "large" farm spoken of may be a small business, as compared with the business done on a "small" farm. A potato-and-truck farm about one and one-half miles from Louisville, Kentucky, has an area of fifty-four acres, some of it under glass. Seven men are employed the year around and five work animals. One team is kept busy in haul- 
ing stable-manure from the city, while nearly every day some farm-product is hauled to market. On a wheat farm in a western State, two men and twelve horses operate about one thousand acres of land. The fifty-four-acre farm near Louisville, however, is the larger business, in that more capital is required to run it, the expenses are greater, and the gross receipts greater. The farm near Louisville is valued at $\$ 700$ per acre, while the thousand acres of wheatland is valued at $\$ 15$ per acre.

How the Census Bureau Defines a Farm.-The Standard Dictionary defines a farm as follows: "A tract of land under one control or forming a single property devoted to agriculture, stock raising, dairy-products, or some allied industry." Every ten years the United States Census Bureau, in getting the data relating to farming, has had to define the farm. Since 1850, when the first complete Census was taken, the definitions have varied, and for this reason it is difficult to use census statistics in making accurate comparisons and drawing conclusions relative to number and size of farms. The fundamental consideration, however, in making these 
definitions seems to have been that of an area organized under one management, the time given to operate it and the size of the income from it. The following definition of a farm was furnished to the Census enumerators of 1910. A farm for Census purposes is all land farmed by one person managing or conducting agricultural operations, either by his own labour alone, or with the assistance of the members of his own household, or by hired employees. The term "agricultural operations" is used as a broad term referring to the work of growing crops, producing other agricultural products, raising animals, fowls, and bees.

A farm as thus defined may consist of a single tract of land or of a number of separate and distinct tracts, and these several tracts may be held under different tenures, as when one is owned by the farmer and another hired by him: farther, when a land-owner has one or more tenants, renters, croppers, or managers, the land operated by each one is considered a separate farm. The enumerators were further instructed to list as a farm three or more acres used for agricultural purposes, no matter what the value of the 
product or amount of labour; also any tract less than three acres which produced at the time $\$ 250$ worth or more of products, or required the continuous service of at least one person.

Distribution of Farms According to Size. ${ }^{1}$-In 1910, 6,361,502 farms were enumerated in the United States, of which 839,166 were under 20 acres in size; about an equal number fell into four groups based on the following area:

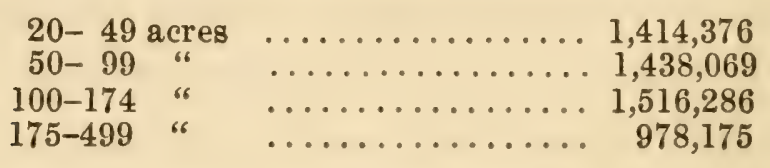

There were found 50,135 farms of 1,000 acres or more, that is, one farm out of every 130. Of every. 9 farms, one was less than 20 acres, four were between 20 and 100 acres, three more between 100 and 500, leaving the rest under 20 acres or above 500 . The average small farm in this country may be considered about 30 acres, the medium-sized about 160 , and the large farm about 500 . In the best farming-regions of the

1 The Census Bureau listed the small areas tilled by croppers or share-tenants as farms. From the farm-management point of view, the cropper or share-tenant should, as a rule, be classed as a labourer rather than as a regular farm-tenant. 
United States, the Middle West, including Indiana, Ohio, Pennsylvania and New York, the farms are medium-sized. Large farms are frequent in the semi-arid region, in the Pacific Northwest, in California, and in the Cotton States. Farms from 20 to 40 acres are principally in the South or are truck farms near the large cities.

The Farm a Human Institution.-The farm, however defined, is distinctly a human institution. It is one of the means by which a human being or a family makes a living. When a farm is run as a business, it may be considered a means by which farmers may demand a share in the products of society. Many farms, however, are not so situated that they can be made to produce profitably; those, for instance, on poor soils, or inaccessible to market on account of distance or bad roads, are likely to have small cultivated areas. Really in such cases farming is not, strictly speaking, a business - the main business being the cutting and preparing of lumber and other forest-products for the market, or perhaps grazing or mining. One or another of these factors accounts for the many small farms 
found in the isolated regions of the United States. In the mountainous parts of Kentucky, West Virginia, and Tennessee the average cost of transportation ranges from 25 to 80 cents per mile. In some districts freight has to be carried on the backs of mules and horses, or even by men, on trails over steep mountains. Being thus disconnected with the mechanism of commerce, and unable to compete for a share in market-products, the farms are relatively small, and the area cultivated is just large enough to produce food for the family and for the few animals kept.

Farms of three to nine acres in the United States develop also near large cities, where stable-manure may be had in large quantities, where there is a market for truck-crops, and where land is high in price. On the other hand, in the plains-region of the West, where the land is fertile and the rainfall low, farms of large area have developed. Where the annual rainfall is from 15 to 20 inches, on the high plateaus east of the Rocky Mountains, farms of less than 320 acres can rarely be made profitable; those of 640 to 2000 acres, with the larger part of the 
area in native grass, are more reliable, and in a series of years will produce a larger average income than farms of smaller size with more cultivated area. Where resources for irrigation are available smaller areas are cultivated with profit. In regions where farm-organisation has grown out of the cattle ranch, the farms are often called "ranches." In the far West this term is the usual one to designate any agricultural project. Here a small poultry farm, for example, is styled a poultry ranch. The word is derived from the Spanish rancho, meaning primarily a mess-room, but used often in Mexico for a herdsman's hut; and so finally it came to designate a grazing farm as distinguished from a hacienda.

The plantation, a type of farm formerly developed in the Southern States, was large in area. The tobacco plantations in Virginia were from 300 to 400 acres in extent up to several thousand acres. The average size of plantation in the seventeenth century was about 700 acres. The tobacco plantation of that time required a large area of land for profitable operation in order to make new land constantly available. As the 
practice of keeping up fertility by means of fertilizers was unknown, and crop-rotations and turning under of green manures was not in vogue, when the land became "worn out" it was allowed to grow up in forest, and new tracts were cleared. Farther south, in the cottoncountry, plantations were still larger, since the production of cotton requires a more extensive system of agriculture than does tobacco. In 1860, the average farm in the South-Central States had about 321 acres, while in the NorthCentral States, the average size was but 140 acres.

The plantation as it existed for more than 200 years in the South was a most interesting and important economic and social institution. The spirit of independence and self-reliance developed almost to perfection among the fortunate owners of plantations. There was very little dependence on the towns for the handling and consignment of farm-products, or of goods produced in other parts of the world, and little need of the services of skilled workmen, or even of professional men. Thus the plantation was a sort of miniature principality, and the owner 
had the authority and the social status among his dependents that would naturally develop under such conditions.

But while the plantation in 1860 was commercially the most important farm-unit, only about six per cent. of the white population in the South were plantation owners, with slaves as labourers. In the hill-country, and in the narrow valleys of the South, some millions of farmers were operating small areas of land, and produced but little of value for the world-market. Many, however, were of the energetic and thrifty Scotch-Irish stock, and kept alive the small family farm-an institution which is winning its way under present conditions.

Cropper and Share-tenant Farms.-In the process of adjustment under free labour there has developed in connection with the plantation the cropper and share-tenant system. The cropper works a small tract of land in tobacco and cotton, and receives as compensation for his labour a share of the crop. As a rule the owner furnishes the equipment besides the land, directs the operations performed, and in many cases the cropper performs a stipulated amount of labour 
for the owner, such labour especially as is required for the general upkeep of the farm and its equipment. While, under the Census classification, the area farmed by a cropper would be regarded as a farm, in reality the plantation or farm employing croppers is in almost all cases managed by the owner or overseer; in many cases the cropper lives on the plantation. Some years he may labour as a cropper and others as a year-hand-from the standpoint of the cropper it is a matter of amount of wages. The regular farm-tenant, or renter, usually farms a larger area, furnishes a part or all of the equipment, and is not customarily compelled to work on demand for the owner. The land operated in this manner is properly a farm. Plantation farming seems to have developed only in such sections of the country as had an abundance of ignorant and cheap labour, or where slavery was feasible and was allowed. The character of the main crops grown, cotton and tobacco, and the climate to which they were adapted were important factors in its development. The season must be long to provide work through the greater part of the year, and the 
climate mild so that the housing of labourers may be inexpensive.

\section{The Typical American Farm.-The typical} American farm, however, began in New England, developed with the advance of population westward, and is the prevailing kind of farm in the Northern and Western States. It is a family farm, the work being mainly performed by the owner and his family. Any extra labour required is usually recruited from other farmfamilies, and the labourer thus employed becomes a member of the household and does not lower his social status in the community by working for wages. This is no doubt partly owing to the fact that working for wages is only a step to becoming a farm-tenant and possibly an owner. Thus the men who labour on such farms are intelligent, have initiative, take responsibility, learn to be self-reliant, energetic and thrifty. Because democratic institutions and customs prevail in such communities, men trained in this way find opportunity to employ their training in successful leadership along lines of industrial achievement and in the administration of political affairs. 
The Real Nature of a Farm.-Having now examined the definitions given by such authorities as the dictionary and the Census Bureau, and having passed in review the main types of American farm, including the ranch, the plantation, and the market-garden, have we any clearer idea of what a farm is? All definitions are made for the purpose of clear thinking, and although in defining terms distinctions are more or less arbitrary there is always some fundamental mark of distinction which the ordinary mind attaches to the thing named. So in a farm there are necessarily two elements: (1) a portion, large or small, of the earth's surface, on which nature will, if properly encouraged, cherish some crop or some animal fitted for the use of man; and (2) a man to assist nature in that operation. The dictionary calls a farm "a tract of land under one control, etc." Now it is this human control, this plan, or in other words this organisation, that forms the essential element of a farm as a means of making money or of making a living. Not alone the number of acres, the qualities of the soil, the climate, the place, but the management of all these factors by the 
farmer in such a way as to bring about desired results, determines the actual value of any given farm.

The same thing is true of other human institutions devised for the same purpose-a bank, for instance, or a shoe-store. The ordinary person's conception of a bank is that of a more or less substantial-looking building, with fire-proof and burglar-proof safes, and well-dressed officials at desks behind bars; the bank always seems to have plenty of money on hand, and on the whole banking appears to be an easy, clean, and generally desirable occupation. The vitally important concern of a bank, however, is the relation of size of loans to profits, the amount of cash to be kept on hand according to the requirements of the season of the year, the placing of its assets where they can earn most, the knowing how much to loan to a given person at a given time. These problems are the vital and significant things about banking.

The uninitiated see in a shoe-store an assortment of various kinds of shoes, and it might appear that to run a shoe-store successfully all that was required of the manager was the keep- 
ing constantly on hand an assortment of goods likely to please customers. Probably this vague idea of this business and others is the reason why so many who undertake them fail at first, if not permanently. Success in the shoe-business depends on the ability of the manager to select goods which will please his customers, and in such quantities as he can dispose of at a profit. The climate is a factor in the shoe business as it is in farming, and a variation from the normal weather of a season subjects the business to danger of loss; and unless these possible variations have been taken into consideration in fixing prices and selecting stock, the business under present conditions of sharp competition must fail.

In the same way the casual observer when passing by a farm is not likely to be impressed with the idea of organisation. The layout of its fields appears to be rather accidental. A few uncultivated patches appear here and there with no apparent reason. He is likely to think of the wasteful habits of the farmer as he sees implements scattered about, buildings arranged in irregular order, and possibly standing in a some- 
what dilapidated condition. The manager of such a farm, however, may see it from an entirely different angle. In his mind the general appearance of the farm is merely incidental to its purpose, the arrangement of the different enterprises, and their equipment. The organisation of the farm does not show from the outside. The general plan, the balance between the proportion of different animals, or kinds of livestock, and the number of acres of each kind of crop he may grow and dispose of to advantage, are more vital than the outside appearance. The location of the farm and arrangement of its buildings may even appear bad from the standpoint of residence and city conveniences, while to the manager their advantages are known, and may have vital signinicance in determining profits. It is often the case, in fact, that a farm that has on the outside the appearance of being substantial and convenient in arrangement and proportion is not a profitable one. At the same time there is no reason why a farm should not both present a good appearance and be organised on a paying basis, just as well as a bank.

How Farm Organisation has Developed.-Many 
established enterprises, of which the farm is one, may be managed successfully by persons who are not conscious of any organisation or plan in particular. We all know good farmers who take pride in the belief that they follow no system or particular rule, who think they decide without logic or are undetermined in their activities. But when the actual practice of all such farmers in a given locality is studied and analysed, it is found that they carry on similar farm-activities during certain seasons, the limits of which are pretty definitely established, the quantity and kind of work done following a normal standard. This will be readily understood if we remember that the farm as a human institution is very old indeed, older than any form of government, or any kind of marriage now in use in civilised countries; and that its growth has been a continuous process, so that present farming practice is in reality a compound of traditions gathered from the remote past, influenced by local conditions, improved occasionally by bold experimenters, changed unconsciously along with other changing customs. Only recently has it been consciously modified by 
intelligent, scientific methods. Therefore as long as conditions remain permanent which have allowed a certain system of farming to become established as profitable, the only necessary thing in attaining average success as a farmer is to inherit the ways and customs of one's father, or to do as the neighbours do.

In point of fact, American farm-practice is largely the result of combining the agricultural traditions of the early settlers with the practical experience of the Indians. In organisation and general management the modern farm has been greatly influenced by English agriculture. The English early brought in hogs, sheep, cattle, horses-all kinds of livestock and poultry, with the exception of the turkey. Most of the common grains, vegetables, grasses, and legumes were introduced from England. Of course all nationalities who helped colonise our wastes or had commercial relations with us contributed something, but English practice both in the details of management and in rural economy seems to be dominant. From England we get the principles of the rotation of crops, and the principles underlying the cultivation of the soil. The laws 
relative to holding and conveying land, etc., have their origin in the land-laws of England.

In New England the land was usually granted to some group of men who desired to form settlements. These lands were then allotted to individuals who had the religious, moral, and political qualities making them desirable citizens. The farms were small and situated near a town of which the church was the most conspicuous and important institution. Certain areas on the outskirts of the town's centre were designated as commons. This grouping of agricultural areas around a common centre was necessary as a protection from the attack of Indians.

In Virginia land was more commonly granted to individuals who became proprietors of large estates. One of the best known of these was the Lord Fairfax estate, including the eastern panhandle of West Virginia and parts of Virginia. During the life of Lord Fairfax holders of land on his estate did not possess titles of ownership. Tenure was based on the payment of a small rent designated quit rent. Later, Virginia 
passed a law making the holders of land in this section legal owners.

Instruction by Indians.-Indian corn and tobacco, together with various garden vegetables, were grown by the Indians when settlers first came to America. The agricultural practice of growing maize was taught New Englander and Virginian alike by the Indians, although the white man did not become a willing learner until convinced that he could not live long on enthusiasm, or on the expectation of finding gold. The corn-land was cleared by "deadening" the trees, girdling them before the sap rose in the spring. The trees afterwards rotted, were blown down by the wind, and finally burned. Exactly the same thing may be seen on thousands of acres in the eastern mountains to-day.

The Indians planted their corn in hills, three to four feet apart each way, and were careful that the three or four grains in each hill were separated by half an inch or more, a practice whose full economic value has only recently been demonstrated by scientific agronomists. They planted corn, beans, pumpkins, and squashes in 
the same field, the cornstalk serving for the beans to climb on. They had devised the underground pit for storing both corn and vegetables, and the corn-crib set up on posts to keep out squirrels and other pests. Many a man now living, who was brought up in the pioneer settlements of the Middle West, remembers very vividly similar practices among white farmers. In fact many of these practices are still to be seen in up-to-date communities; and in the mountainous districts of the East the Indian method of cultivating the corn-crop is followed almost precisely, save that the "bull-tongue" plough, wooden harrow and corn-knife take the place of the shoulder-blade of the deer and crooked sticks as cultivating implements. The wooden husking-peg used by many boys on farms thirty or forty years ago was invented by the Indians.

Even the paled-in garden, so marked a feature of the farm layout in the eastern mountains today, was of Indian origin; and the scarecrow, so conspicuous an object in many a small cornfield, undoubtedly developed from the Indian practice of stationing a boy on a platform in the centre 
of the field, armed with bow and arrows to kill or frighten away crows and other enemies of the crops. Tobacco growing, although later greatly modified, was directly learned from the Indians.

\section{The Future of the Farm.-So the age-old customs} on both sides of the world became blended in the common farming methods of the United States. But ancient as the farm is, it is still full of youth and promise. The scientific research that has turned the world topsy-turvy with its inventions and discoveries, and the social research that has begun to perform almost as startling miracles in its way, have only recently turned their attention to the problems of the agriculturist. Yet already, not only on isolated farms here and there, but in whole communities may be seen the changes that come from the free use of the power of steam, electricity, and gasoline, and also from a conservative development of cooperation and social action.

Thus a farm, considered as an outgrowth of the past, conceived in the light of its opportunities and possibilities for the future, is in a sense a living, interesting and complicated institution, 
worthy the best effort of mind and physical strength. Opportunities for larger profits, and the more general desirability of farming as an occupation, lie along the line of organisation in the light of a comprehensive knowledge of all the resources at hand.

LITERATURE RELATED TO THE SUBJECTS DISCUSSED

Thirteenth Census of the United States.

Economic History of Virginia in the Sixteenth CenturyBruce, 2 vols.

Virginia and Her Colonies-Fiske.

History of Virginia-Kercheval.

Corn Culture by the Indians-New York Bulletin.

Industrial History of the United States-Coman.

Rural Economics-Carver.

Letters from an American Farmer-Crevicoeur.

English Agrarian Problems During the Sixteenth CenturyTawney. 


\section{CHAPTER II \\ TYPES OF FARMS}

IN the chapter preceding this it was pointed out that the organisation of farms varies according to situation and historical development. In some places the typical farm is large, in others small; some farms derive nearly all their income from a special enterprise, such as wheat, dairy products, fruit, or fat cattle, others are diversified, deriving an income from several sources. We would naturally expect that the most successful farms would be those which had so adjusted their organisation as to secure the advantages of soil, climate and market opportunities.

It is of practical importance for the farmer to understand the conditions that have influenced the development of varying types of farming, and that have enabled such types to be profitable, so that he may have a basis for judgment in 
readjusting a type already established, or, in case he has occasion to decide on a type in new surroundings, so that he may use his judgment intelligently. Farmers migrating into a new country have, as a rule, tried first the type of farming and the farm-practice with which they have been familiar, with little consideration for soil, climate, or the market-factors that may determine success or failure. Gradually, and at considerable loss, the type of farming must be adjusted to these factors. Those who fail to make this adjustment will of necessity go into some other line of work.

Very few who are managing successful enterprises are conscious of the process by which successful organisation has been secured-of the failures and successes of those who have had a hand in building them. Just so in farming. Men have tried different ways of doing thingssome fail, others succeed. In the end, those who happen to be most favourably situated, who have hit upon the right enterprises, and the right proportion in the adjustment of these to market-opportunity, and to the time available for handling them, will win success. Thus the 
type gradually evolves which is best adapted to any given place.

The farmer is familiar with the dairy type and the beef type of cattle; with the draft-horse type and the saddle-horse type. The general meaning of "type" is well understood. When we compare farms from the standpoint of the means by which they are to accomplish results, that is, to produce an income, we naturally classify them in a similar manner. The fruit farm, the truck farm, the wheat farm of the West, the tobacco farm, the cotton farm of the South, the dairy farm of New England, Wisconsin, and Minnesota; the corn-and-cattle-feeding farm of Iowa and Illinois;-all these are illustrations of various types of farming which have developed in the United States. When these classifications are made there is in mind a dominating or characteristic enterprise which makes one farm different from another. In a general way, livestock farming is characteristic of the northern zone of the United States. Going south, the proportion of income from livestock decreases, and that from products raised directly from the soil increases. It would thus 
seem that there were certain natural or economic advantages which cause the farmer in the Northern States to seek profits from livestock and in the Southern States from field crops. As will be seen in the further course of this chapter, this difference in the development of farming enterprises is in fact due to such advantages.

Such natural resources and factors as soil and climate would tend to make such differences in development permanent. Economic conditions being an important factor, such natural advantages will not of themselves insure success, yet certain unfavourable natural conditions are often controlled-for instance, the cattle-tick has been controlled in the South to such an extent that in many localities the raising of cattle has become profitable.

In order to understand the principles underlying the development of types of farming, attention is directed to regions where definite types have developed.

Dairying in Wisconsin.-In southern Wisconsin, for instance, the dairy industry has developed to a marked extent, so that to-day Wisconsin ranks first in the production of dairy-pro- 
ducts. The industry is pretty well distributed over the southern half of the State, yet more concentrated, however, in certain counties. It is an interesting fact that within this area special kinds of dairy farming, have developed. At the present time the making of Swiss cheese is largely confined to the high, rolling land, rich in lime, found in Green, Dane and LaFayette counties, and the near-by region. The elevation above sea-level here is about 1,000 feet. The mean summer temperature is cooler than in lower surrounding altitudes. The summer rainfall is normally abundant, amounting to nearly four inches per month during the months of May, June, July, and August.

It is said that the same kind of cheese is made in Switzerland on similar soil and in a climate with similar characteristics. Nearly half a century ago the cheese industry started in Jefferson county, Wisconsin, but has shifted eastward to the cool shores of Lake Michigan where most of the American cheese is now made, and westward onto land rougher in topography and higher in altitude, thus having a climate somewhat cooler. On these limestone highlands all 
the Swiss cheese of the United States is produced. Probably the factor of land-value had something to do with this shifting, when the lower, more level, land became more valuable for a different type of farming. In 1875 Jefferson county produced more cheese than any other county in Wisconsin while to-day it leads the State in butter production and the cheese factories have been almost entirely driven out. Corn and silage encourages winter dairying and butter production while pasturage encourages summer dairying and cheese production. At present, more than two-thirds of the land where the Swiss-cheese industry flourishes is in pasture, showing that rough land, if adapted to pasture-grass, is about as valuable for this purpose as is the more level and rich land. There may be hundreds of localities in the United States as well adapted to this industry, but the facts given illustrate the point that a given farm-enterprise once started will tend to become established where conditions are most favourable for its development. Many localities in the United States might be pointed out where certain types of farming have been 
started and failed because conditions did not prove favourable for their development.

A general climatic factor in the northern parts of the United States, which has an important relation to the dairy type of farming, is the proportion of time that may be utilised in work on field-crops to the total working days of the year. In the latitude of southern Wisconsin, northern Illinois, Indiana, Ohio, and Iowa, at an altitude of 700 to 1,000 feet, the number of days available for field-work will not exceed 150 . The dairy type of farming gives an even distribution of work throughout the year. It gives the farmer profitable employment during nearly half the year when practically no work can be done on field crops.

Cattle-feeding in the Corn-belt.-A type of farming is found in northwestern Iowa which is common to many parts of the corn-belt. The region between the grazing districts of the less humid areas of the West and the stock-market centres of the East has been favourable for the development of the cattle-feeding industry, and a farmorganisation there has been adapted to this opportunity. In the first place, the soil and 
climate are adapted to corn-growing, the soil being a deep black loam warming up quickly in the spring, which in that latitude is an important factor in making the growing season sufficiently. long to mature the corn-crop. The late fall and the winter months are normally cold and dry, enabling the farmer to gather a large crop. Cattle require little expense for sheds, and fatten well on corn with oat straw and a little clover hay for roughness. This type of farming will continue to be profitable as long as the conditions supporting it continue

The present type of cattle-feeding farm like the dairy farm, enables the farmer to occupy his time to advantage. Pioneer farming, when land was cheap in that region, was of the grain type-wheat, flax, corn, and oats being the principal sources of income. This kind of farming did not occupy the available time for work as fully as does the present one, but on account of the cheapness of the land, and the good prices for grain-products, it was for that time probably the most profitable type. Besides, in the early history of this region clover did not grow vigorously; later it became adapted to the soil, 
and is now one of the important factors in making this a corn-growing section. When land became higher in price corn, wheat, oats and flax did not produce a sufficient labour-income. Under the pioneer organisation the land lost in fertility, and the farmer could occupy his time only during the short period of about 150 days available for field-work. Reorganisation gradually took place. Clover became adapted to the soil and was introduced into the rotation as a soil-improver, and as a valuable hay and pasture crop, and cattle-feeding enabled the farmer to occupy the winter months profitably.

Mixed Farming in the East.-The type of farming developed in the great limestone valley of Virginia is an interesting one for study. It is not only common in the best farming-district of the Middle Atlantic States, but is a fair illustration of the more general prosperous American farms. An ordinary farm in this section is about 215 acres in area, of which 10 acres will be in woodlot, 5 acres in orchard, 72 acres in pasture and waste land. The balance will be in ficld crops-wheat 63 acres, corn 35 acres, 
meadow 30 acres. Another distribution of fieldcrops on a similar farm in the same section might be-corn 48 acres, wheat 30 acres, clover and timothy 50 acres, used partly for meadow and partly for pasture. This distribution of field-crops would indicate that in a general way the farms are planned for two rotation-systems -one in which wheat predominates and the other in which more corn, clover and grass is raised. A farm on which wheat is dominant might have as a source of income the following enterprises:

Stock-products:

50 lambs, say................. $\$ 280$

Wool ........................ 25

30 hogs ...................... 600

130 chickens ................... 100

7 dairy cows .................. 250

2 horses or mules .............. 300

10 head of cattle .............. $500 \quad \$ 2,055$

Crop-products:

63 acres of wheat $\ldots \ldots \ldots \ldots \ldots \ldots 1,000$

5 acres of apples $\ldots \ldots \ldots \ldots \ldots \ldots \ldots \ldots \quad 800 \quad 1,800$

Forest-products:

Logs or ties $\ldots \ldots \ldots \ldots \ldots \ldots \ldots \ldots$

Total

The income from such a farm as this would bo about equally divided between livestock and crop-products, and would be for that reason a 


\section{TYPES OF FARMS}

general farm with stock-products slightly predominating. The total expense of such a farm, including all charges for interest on a total investment of about $\$ 25,000$, depreciation, etc., would range between $\$ 3,000$ and $\$ 3,500$, leaving a labour-income of $\$ 500$ to $\$ 1,000$. On this type of farm nearly all the corn and hay products would be fed to stock. Now and then a few tons of timothy hay might be sold. In case more corn and hay were raised, the sources of income would, on the average farm, be approximately as follows:

Stock-products:

16 beef-cattle ...............\$1,280

50 lambs ................... 280

Wool .......................... 25

45 hogs ...................... 800

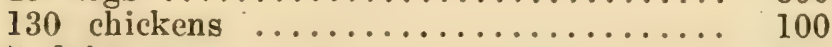

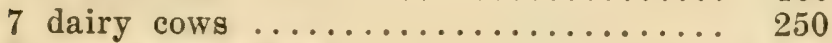

2 horses or mules ................ $300 \quad \$ 3,035$

Crop-products:

30 acres of wheat $\ldots \ldots \ldots \ldots \ldots \ldots \ldots \ldots 500$

5 acres of apples $\ldots \ldots \ldots \ldots \ldots \ldots \ldots \ldots .800 \quad 1,300$

Forest-products:

Logs or ties

Total

$\$ 4,335$

On this type of farm nearly seventy per cent. of the income would be from stock-products, thus making it more distinctly a stock-farm. 
The expense of labour on such a farm would be somewhat decreased and a little better distributed, but the total expenses would be increased, since cattle would have to be bought for feeding purposes, and some extra concentrated feed would also need to be purchased. The total expense on such a type of farm would be $\$ 3,500$ to $\$ 4,000$. The farmer who had skill in selecting quality of stock and whose credit was good for borrowing money when needed, would have an opportunity to make such a farm yield a larger income than could probably be done on the first type of farm. With more stock, the yield of crops could be increased with less cost. A careful study of farms in this region would no doubt demonstrate the fact that one or the other type was established, and persisted where situated, because of some natural or economic advantage.

Bluegrass Farming.-In travelling through that part of Kentucky known as the Bluegrass Region, one is impressed with the large proportion of level, rich, agricultural land in bluegrass pasture. A striking and significant feature in the landscape is the large forest-trees scattered 


\section{TYPES OF FARMS}

over the farms, showing that farmers consider it important to provide shaded places here and there for grazing animals. Until recently the breeding and training of saddle-horses and the raising of cattle for export were profitable agricultural enterprises. The grazing and feeding of cattle, sheep raising, and the raising of various classes of horses and mules, are still impor'tant enterprises; but restrictive laws relative to racing in other States, which formerly provided a profitable market for this class of horses, has naturally been a factor in the development of new methods of farming.

Within the last twenty-five years the planting of Burley tobacco has become one of the dominant enterprises in this region. Now tobacco and wheat are the principal sources of income direct from the soil. It is evident that greater diversity has resulted.

The income from a modern, successful, bluegrass farm of about 300 acres might be stated as follows in the order of magnitude of enterprises:

Live stock $\ldots \ldots \ldots \ldots \ldots \ldots \ldots 3,400$

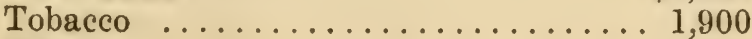

Wheat $\ldots . \ldots \ldots \ldots \ldots \ldots \ldots .600$ 
Livestock products ............ 500

Corn .................... 200

Hay and forage ............. 200

Miscellaneous ................ 100

Total

$\$ 6,900$

Broadly speaking, types of farms may be classified primarily on the basis of percentage of income from the two sources, livestock and plants. Taking three great groups of States, and comparing the source of income on this basis in percentages, it will be found that:

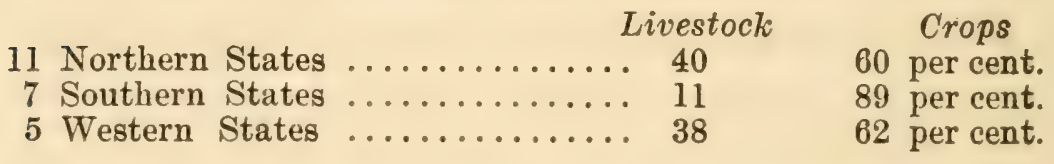

Within these groups will be found some types, such as the grain-type found in Kansas, Nebraska, South Dakota, and Minnesota, where about 50 per cent. of the income is from cereals. In such States as New York and Wisconsin about 25 per cent. of the total income is from dairy-products, showing a tendency toward the dairy type. Two cotton States show that 60 per cent. of the entire income is from cotton alone, indicating distinctly cotton-types of farms.

Changes in Type.-In almost every region where economic conditions are especially un- 
stable, old methods are disappearing and new ones are developing. On the western slope of the Allegheny Mountains, in West Virginia, in localities where towns and cities are growing, the change to new and more profitable systems of farming has not been sufficiently rapid to show as yet the type that should prevail. In a small county, where there had been time for readjustment, three profitable types were discovered. The general farm, 200 to 300 acres in size, so placed that a profitable income was received from livestock and field-crops; and the dairy and fruit farms, 60 to 100 acres in size, were more profitable than the average large farm. A still more profitable type was the small truck and dairy farm between 10 and 60 acres in size, the spare time of the owner being used in doing outside work with a team. This last type made the largest net income. In another district, under entirely different conditions, where grazing was profitable, the large farms of 400 to 1000 acres were most successful. The smaller farms attempting to handle the same enterprises in the same way will have to change or go out of business. 
The history of farming shows many examples of change in types of farms. The history of English agriculture tells how at one time areas thickly occupied by small farms two and a half to thirty acres in extent, gradually changed into stock farms of 200 to 1000 acres. Similar alterations are bound to occur in our own country. In special localities, such as those near large and growing cities, the larger general diversified farms are dividing into smaller units, and are the coming types such as the dairy or truck farms. On the other hand in some localities of the Middle West farms grew larger during the last decade, tending toward the more distinctly stock type of farms. Present indications, however, point toward a more intensive agriculture which will result in smaller farm units.

Those who are doing the farming are not conscious of developing any particular type, nor do they have this in mind. When thought is given to the problem of change in methods or in organisation it is to select particular crops or livestock-enterprises that appear to have possibilities of more profit. It may seem that advan- 


\section{TYPES OF FARMS}

tages are to be secured by more diversity, or by enlarging the farm acreage, getting control of more capital, etc.

In the analysis of a farm-business it is of primary importance to have the type so defined that the problem of finding out the strong and weak places in the organisation may be simplified. 


\section{CHAPTER III}

\section{ADVANTAGES GAINED BY SITUATION}

IN 1910 about 46.2 per cent. of all the land in the United States was in farms; of this amount, 54.4 per cent., or about a quarter of the whole area, was improved. Of the unimproved land in farms, about one-half was in woodland, and onehalf unimproved. In travelling over the eastern half of the United States, one observes large areas of forest-growth, especially in the mountainous districts. In the North-central States, on the other hand, more of the land is under cultivation. In the better farming regions of Illinois, Minnesota, and Iowa, about 85 to 90 per cent. of the farms is under cultivation, and nearly all of the land-area is in farms.

Reasons for Choice of Farm-lands.-In occupying land in the United States, farmers have selected those areas that seemed to them the most profitable, for the chief factors entering into the selec- 
tion of farm-lands have been natural productiveness, faith in ultimate prospects, and in rise in value. In a new and undeveloped country the first settlers have usually had to experiment with soil-conditions. Those who ventured into the unoccupied regions of the West did not select the most productive land. Other considerations at the time were of more vital importance. Fuel and water were necessities, and they had to have access to these.

In western Kentucky, for instance, the comparatively poor shale and sandstone soils were first chosen by white settlers. These soils were heavily timbered, and had an abundant supply of water in small streams and in springs. The more fertile soils derived from limestone were largely treeless, and for that reason would have been better adapted to agriculture, but most of the streams in the limestone area found channels underground, so that reliable springs could be found only occasionally. Farmers, however, soon learned to store surface-water for stock in the sink-holes common there. This device, and the making of wells and cisterns, gradually enabled them to make use of the more productive 
lands. Much of the most fertile agricultural lands in the United States could not have been made available except through means of securing a water-supply for men and animals.

Railways have been a principal factor in the selection of the best agricultural lands. These have not only settled the fuel-problem, but made markets accessible, and transportation-rates cheap. Railways have made it possible to carry corn, hay, butter, and meat-products from the naturally productive farms in the North-central States to eastern and southern markets more cheaply than the same things can be produced at home.

The Best not Always Available.-It is a general idea that favourably placed agricultural lands are scarce - that most of the areas having a productive soil and humid climate are owned and held at prices commensurate with the advantages they include. There is a certain measure of truth in this general belief. It must be remembered, however, that almost every generation since the country began to be settled took this view of the future, because to the majority of people opportunities have always seemed lim- 
ited. Moreover, those conditions that make opportunities are dependent on forces over which persons individually have no control. The rich Shenandoah Valley held out no opportunities to Virginians until Governor Spotswood found a way over the Blue Ridge Mountains. Daniel Boone discovered a way over the Cumberland Gap to the bluegrass region of Kentucky, thus making accessible a large area of fertile land. The building of railroads opened up opportunities on the prairies of the Mississippi Valley.

It seems now that agricultural opportunities in the future must occur through a study of the resources and factors that exist in areas already occupied.

Basis of Value.-Under normal conditions, agricultural land-values are based on the capacity of a farm to yield a satisfactory income under its existing management, plus whatever speculative value it may have. Such farms offer no special advantages to prospective buyers unless by superior organisation or more skilful management they can be made to furnish better incomes. When land becomes very high in 
price, only the most skilful farmers will either own or rent the land.

This principle is illustrated by many examples in the history of agriculture in the United States. The prairie-lands of the central West were first utilised as grazing-lands. When these lands were demanded at a high price for general farming purposes, the cattle-men left them, and the grain-farmers took possession. As the land advanced in value, grain farming became less and less profitable, and other types had to supplant it. In such cases of reorganisation the former owners either sold out and new farmers came in, or the former owner adapted his farm to new conditions.

Personality in Settlement.-Certain types of farming demand farmers of special training. Thus, near a large city, where trucking may be profitable, only farmers skilled in this branch of agriculture will remain in the business. The unsuccessful ones will have to select other types in a different locality or find other employment. This explains the fact that groups of farmers bearing a certain nationality will be found occupying farms in a group-most successful 
truck-farmers are of foreign origin. The dairy farms of Wisconsin, which produce our Swiss and American cheeses, originated among German and Swiss immigrants. In the far West, in the vicinity of such cities as San Francisco, the Chinese or Japanese do most of the truck-farming.

An interesting and important fact to be noted relative to the selection of agricultural land is that the migration of people west of the Allegheny Mountains has proceeded quite definitely along lines of latitude. This parallelism of migration has probably characterised pretty much the whole migration-movement in the United States during the past one hundred years. In parts of Oklahoma and Texas every third man may be recognised as being from Kentucky or Tennessee. The ancestors of most of the present population of Kentucky and Tennessee came from the Valley of Virginia, or from the piedmont and coastal regions of North Carolina. People from New York, Pennsylvania and New England have gone across the Northern States to the Pacific Ocean. Migration from European countries has proceeded in a similar man- 
ner. Scandinavian and Russian farmers are found in Minnesota and the Dakotas and German farmers are scattered over the central portion of the United States from New York and Pennsylvania to Missouri and Illinois. A few farmers from southern Europe are found in colonies along the eastern and southeastern coasts.

Social Influence on Distribution.-Many factors have combined to influence people in selecting new residences-climate, natural routes of travel, railroads, nationality, religion, political and social ideals. Farmers, in moving from one district to another, take with them, of course, not only their habits of farming, but other institutions. Thus, wherever the New Englander went there was planted the family farm, the town-system of local government, the public school, and the small college. These, of course, became modified in time to the demands of new surroundings and the conditions of general progress. Before slavery ceased to exist in the South the plantation form of farm-organisation was moved westward wherever favourable agricultural areas were obtainable. This type of farm required for operation a large amount of 


\section{ADVANTAGES GAINED}

capital invested particularly in land, labour and power-equipment. The small farmer who could not command a large amount of capital for such an organisation felt compelled to withdraw from these more favourable agricultural areas to seek opportunity and residence on land less favourable for farming, but where independence and the pioneer standard of respectability could be maintained.

As long as rich, productive lands were available railroad building went on at a rapid rate, the invention of agricultural machinery developed to meet the requirements of agricultural production on a large scale, and the expectation of and faith in coming prosperity continued to be realised. It was only when farmers came face to face with the problems of a dry country that this faith in spontaneous and inevitable prosperity received a severe shock.

Problems of Location.-In the older agricultural regions wherever farmers have had to deal with difficult problems those who could have run away from them to secure advantages in a newer and more agriculturally promising West. So fixed has this national habit become that 
large numbers of farmers have given up citizenship in the United States and crossed the boundary into Canada or Mexico, in order to secure the advantages believed to be attached to a new and undeveloped country. Because in recent years many have failed to realise expectations in these undeveloped regions, attention has turned to securing advantages in other ways. This involves study and the intelligent working out of problems by individual farmers, aided by the agricultural literature and scientific knowledge put at their disposal by the States and the Federal Government.

By intelligent selection of a location for a farm, waste in labour and other resources may be avoided, and such natural and economic advantages may be secured as will save expense in adapting the farm to the purpose intended.

The problem of organising a farm in a new and undeveloped country is a difficult one, for the reason that few farmers have clearly in mind just what type of farming they ought to follow. From this point of view, the location of a farm should be made a matter of as serious and intelligent calculation as the location of a 
department-store, a bank, or a factory. The factors that make such enterprises successful are pretty well understood, and no one venturing: on one of these enterprises would fail to make calculations, based on all available data, or to hire the expert services of those who make a business of calculating the feasibility and practicability of such undertakings.

Although the science of farm-management is not yet sufficiently developed to afford the bases of such complete calculations, yet sufficient information is available to assist very materially. in the selection of a location.

The vital and important problem of the farmer in managing the farm is to secure such natural and economic advantages as may be within his reach or his ability to secure. These advantages are obtained either by settling where they prevail, or by devising such means of control as will secure them. The natural resources to be taken advantage of are those dependent on soil-conditions, climate, topography, and accessibility to market. The economic resources to be secured are such as depend on transportationfacilities, market-agencies, market-reputation of 
the community, banking-facilities and credit. Natural resources differ from economic resources in that they are more permanent, relative to location, while economic resources are necessarily more liable to change. Advantages which are of secondary importance from the point of view of farm-management, but which may be of primary importance from the standpoint of the family, are the reputation of the neighbourhood, and the presence of good schools, churches and other social advantages.

Soil Surveys.-The United States Bureau of Soils had made soil-surveys covering an area of 703,235 square miles, up to July, 1913. These surveys have been made in various States, and an elaborate classification created on the basis of the physical and mechanical properties. The types of soil found in a definite area are mapped in published bulletins, and the productiveness of each type is in a general way measured in terms of yield-capacity. These are available helps in determining the advantages any neighbourhood offers. The real agricultural value of soils is dependent not only on natural fertility of the surface-soil, but upon the manner of its forma- 


\section{ADVANTAGES GAINED}

tion, the structure and condition of the ground beneath, the character of the underlying rock (when it is residual), the amount and size of stone embedded in it, its drainage capacity and topography. Many of these conditions form impediments in the use of machinery. The farm-value of land depends also largely on the number of acres of tillable soil that can be farmed in a single tract. Unless a considerable area of land that is tillable can be thrown into a field, men, horses, and machinery work at a disadvantage. Conditions of this kind prevail especially in mountainous regions, but they prevail to some extent, at least, in all regions where the soil is residual. Soil-surveys have not specified all these conditions, but in general farming they are of the greatest importance. A general knowledge of the geology and physical geography of a region, in addition to the soilsurveys made, will aid in interpreting the agricultural possibilities of a soil-type in those regions, especially where it is derived from the rock beneath.

Comparative Qualities of Soils.-The soils in the eastern half of the United States are generally 
benefited in their productive power by the application of lime, as well as by commercial fertilisers. Much of this land has a tendency to be "sour," making the growing of red clover and alfalfa especially difficult. Certain crops are found to be "acid tolerant," such as Irish or sweet potatoes, crimson clover, and to some extent corn, cow peas and soy beans. Thus a type of farming might become adapted to "sour" soils. In the western part of the United States much of the soil has a tendency to be too alkaline, and this tendency is increased by irrigation. There are, of course, "sour" soils in the West which would be benefited by the application of lime. The problem of alkaline soils is connected with low rainfall and imperfect underdrainage. In the great agricultural area of the Middle West, neither of the above conditions seem now to exist to the extent of creating a serious problem.

The point is that in estimating the value of a proposed location from an economic point of view, all these factors should be measured and added to the cost of the land, when comparing the advantages with those of another place. If 


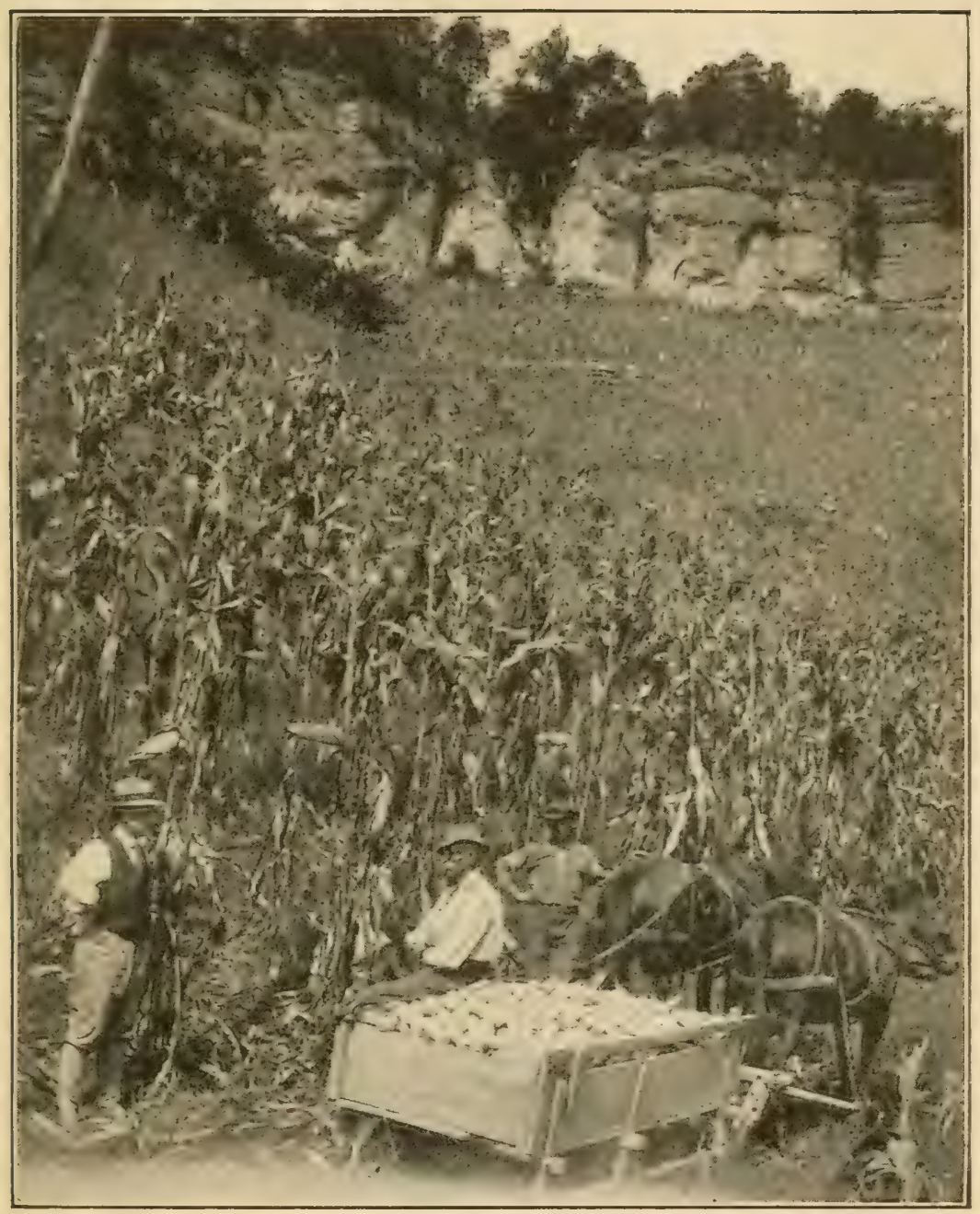

Fig. 2. A favourable situation for field crops on a mountain side below limestone cliffs 



\section{ADVANTAGES GAINED}

a farm were twenty or thirty miles from a shipping-point, the application of commercial fertiliser or lime would, as a rule, be unprofitable on account of the expense of hauling.

In some parts of the United States soils have peculiar properties in inducing certain specific qualities in plants. An illustration is tobacco soils. In western Kentucky, the dark-tobacco district, a certain quality of tobacco (dependent partly on the soil) is produced for which a special market has been developed, and the same quality cannot be produced elsewhere; consequently that district has a monopoly of that kind of tobacco. It has been found recently, also, that particular soils and climates grow a good quality of hard wheat. For instance, a given variety of wheat grown in the semi-arid climate of the Middle West is different in its physical and chemical characteristics from the same variety grown in a more humid climate. Thus the environment of plants has a great deal to do with the production of quality, which is often reflected in the price of such crops.

A multitude of particular advantages of soil are known to the practical farmers of a region. 
They have learned to measure them in selecting sites for certain types of farming, and for the growing of particular crops; and it is always wise for a prospective buyer in any locality to interview the resident farmers, and learn why it is that certain areas on their farms are allowed to grow up in timber or are devoted to permanent pasture. The chances are that the owner has a good reason for this, and has found from experience that it is not profitable to cultivate such land under present conditions.

On a high, level plateau in a South-central State may be observed the remains of many commercial orchard-plantings. In many cases the nearest shipping-points were in the valley 1,000 to 1,200 feet below, and 15 to 20 miles distant. In addition to these disadvantages the soil was poor and the topography ill suited. Of course most of these orchards were abandoned. Such orchards were not planted by native farmers, but by thrifty, enterprising immigrants and business-men from outside, who usually despised the achievements and practices of native farmers. These attempts in establish- 
ing fruit-growing proved to be of benefit, however, to the region in general, if not to the unfortunate individual starting them, for at the present time thrifty and profitable orchard and small-fruit enterprises are established there in more favourable situations.

A few years ago, in one of the Rocky Mountain States, a company started a large irrigation-farming project on some 50,000 or 60,000 acres of land. A system was devised by which five-acre tracts could be irrigated, and around each tract lay an area of 100 or more acres on which crops could be grown during the most favourable years without irrigation. The company promoting this project, costing many thousands of dollars, did not take into account the fact of an elevation of 7,000 to 8,000 feet above sea-level, where the growing season was 100 to 120 days, and where nothing except cabbage, timothy, and a few other cool-weather crops, could be grown. They did not consider that even such truck crops as could be raised would have to be shipped with difficulty many miles to an uncertain market. As a result of not taking into account such physical facts, this company 
naturally failed, and the land at the present time is on the market at an exceedingly low price. Profitable farming may be established in such a region, but it must be of a sort adapted to the situation.

Dependence on Climatic Conditions.-The suitability of a farm-location for any particular type of farming is dependent on climatic conditions, such as rainfall, growing season, and available days for field-work, and to such disadvantages as diseases, insect-pests and the weeds incident to the local soil and climate.

Climate is an important factor in farm management. The Weather Bureau of the United States Department of Agriculture has taken records during many years past of climatic observations in all parts of the United States, and has published them in bulletins showing the average amount of rainfall and other features for many localities. The temperature-records for each month of the year, and the frost-data, from which may be calculated the growing season, are important things for the farmer and the student of farm management to analyse and interpret. 
Other things equal, the benefits from a given amount of rainfall depends on situation. Twenty inches of rainfall from May 1 to October 1 in a district where the summer is long and hot may not be as efficient as fifteen inches during the same period where the average temperature is lower. It is well known that the nature of the soil, and the wind-velocity, modify the effectiveness of rainfall. On account of all these factors combined the statement of the average rainfall of any region indicates the degree of humidity only in a general way. England, for instance, has an average rainfall of less than forty inches, but has a notoriously humid climate.

The availability of the rainfall at a given place depends very largely on its distribution, the winds and the condition of the soil. Where the rainfall is even as low as twenty inches, and where most of it comes during the growing season, where the soil is such that it will retain moisture well, and dry, hot winds do not prevail, the climate might be sufficiently humid to grow certain field-crops very advantageously. The ability of the soil to absorb and retain sufficient moisture is sometimes more important 
than the amount of rain that falls. It would not make any difference how much water is poured into a leaky pail if it runs out as fast as it is poured in. Just so with soils-if the subsoil is of such a nature that it will retain but little moisture, and will not transmit freely ground-water to plants, statistics of the amount of rainfall would have little significance, although frequency might be an important factor. Again, in a highly humid section the soil may be shallow, and lying on rock incapable of transmitting much moisture from below. In this case, a few days drought during the hot weather may burn a crop. It is for this reason that in some specially humid districts, where the annual rainfall is as high as forty-five or fifty inches, patches of ground here and there are observed to be covered with cactus, so characteristic of the desert.

\section{Calculating Amount of Working Time.-The} growing season is generally defined as the number of days between the average date of the last killing frost in spring and the average date of the first killing frost in the fall. It is deter- 
mined primarily by latitude and altitude. Soil conditions, topography, and direction of exposure are secondary factors that determine the growing season at various points in a country.

In going north or south from a given point the growing season varies approximately at the rate of one day for every seven miles in latitude and one day for every 60 feet in altitude, varying somewhat, of course, under local conditions.

An important farm resource but one generally overlooked is the number of available days for field work. These are limited primarily by temperature. The secondary factors are rainfall, soil-condition, topography and field-exposure. Like the growing days, such available days will vary with the distance north or south of a given point, and also with altitude.

In central Georgia, farmers may employ about 250 days of the year working on crops in the field; in northern Tennessee and southwestern Kentucky about 180 days; in central Iowa about 140 days; in central western Minnesota about 130 days; on top of the Allegheny 
Mountains (3,500 feet elevation in West Virginia) about 130 days, and in North Carolina, at a similar elevation, about 150 days.

In places where 200 to 250 days are available for field-work, an important advantage is secured for growing field-crops. It is partly because of this advantage that in southern latitudes the incomes direct from crops are greater proportionately than from live stock. In a general way the same relation holds good relative to elevation. On the higher elevations in the South, more of the farm income is derived from stock products, showing that the farmer in such locations believes that a greater proportion of his time spent on live stock brings in a better farm income.

A soil that drains well and is not made up of too fine particles, or a loamy soil well filled with vegetable matter, will allow a longer season for field work in the same latitude and altitude than will ill-drained, non-porous, heavy clay soils. The soil condition alone may cause a variation of 10 to 20 days available for field crop work. 


\section{ADVANTAGES GAINED}

\section{Effect of Climatic Conditions on Size of Farms.}

Going from the eastern part of the United States westward across the Great Plains, the most noticeable climatic change is the decreasing rainfall. As the changes of temperature observed in going north or south are reflected in the types of farming, the variation in rainfall going east or west shows its effect in the size of farms.

The idea that a good size for a family farm is about 160 acres has long held sway in this country and was embodied in the Early Homestead law. Under conditions of ample rainfall and good tillable land, this made a good sized family farm. On specially fertile soils and under conditions where a more or less intensive type of farming is profitable, even 80 acres of land is large enough.

Generally speaking, however, where the land is poor in quality or where there is lack of rainfall, farms must be larger in size to be equal in production. For instance, in the Great Plains region east of the Rocky Mountains, where rainfall and temperature are the outstanding factors in profitable agriculture, farms must be 
considerably larger than 160 acres to be equivalent in productiveness. This, of course, would not apply to irrigated farms or farms on riverbottom lands. Except in such favored places the farmer must be reconciled to extremes in crop production. He must count on years of low yields and occasional failures, which are compensated for by years when yields are high. Average yields, though, will be low as compared with yields on farms farther east.

In the dryer parts of this region where there is still room for the development of farms, it is rarely the case that a family farm can safely contain less than 640 acres. When the rainfall is as low as 12 to 15 inches, 1000 to 2000 acres without irrigation would be about the least number of acres a farm should contain to be profitable. A large amount of the land should remain in native grass to be utilised by live stock. Live stock combined with grain raised under dry farming practices is, as a rule, the only safe type for this area.

When these principles are observed in choos- 


\section{ADVANTAGES GAINED}

ing a farm in a new country, the chance of failure is greatly lessened. Furthermore, in buying or renting land under such circumstances the buyer should always consult farmers experienced in the locality on such points as the minimum size that a farm should be, how much of it should be cultivated, and the amount and kind of live stock that should be kept to properly utilise the pasture.

The failure to observe these safeguards in undertaking the business of farming under unfamiliar conditions has often resulted in financial losses and frequently has led to disastrous and even tragic results.

Accessibility of a Market.-Accessibility of the shipping-point is an important advantage to be sought in locating a farm. This often determines the type of farming that may be profitable in a location. In the case of general farming a distance of more than ten to twenty miles from the shipping-point will, as a rule, make the raising of crops for market unprofitable. When the distance is more than one day's drive to and 
from the shipping-point the expense of hauling will consume profits. For illustration take a wheat-crop. One man and a two-horse team may, on an average road when dry, haul fifty bushels. If the man and team went such a distance as to require staying over night the cost would be, under average conditions :

1 man and team, 2 days@ $\$ 4.00$ per day............. \$8.00 Meals and lodgings for man ................. 1.50 Livery bill for horses .................... 1.25

Total

This would make the hauling cost $211 / 2$ cents per bushel, which in most cases would more than eliminate profits.

Peach-orcharding as a commercial enterprise is seldom profitable when the market is more than five miles distant. In the case of apple orchards the distance may possibly be as great as one day's travel to and from the shipping-point. A 20-barrel load may be hauled over a fairly good road with four horses 10 to 12 miles and return in one day. The average cost of that operation in the East would be about $\$ 5$ per day. This would be 25 cents a barrel for transportation. Should such charges exceed 50 cents per 
barrel, profit, in most cases, would disappear.

The average cost of hauling farm products in the United States is not far from 20 cents per ton, per mile. On mountain roads in the East the cost of hauling various commodities varies from 20 cents to 87 cents, the average being about 39 cents.

One place may have an advantage over another because of freight rates and shipping facilities. There are localities which have peculiar natural advantages for growing certain crops, but the cost of getting the products to market is too great, and with some crops of a perishable nature the time of getting the product from the farm to the consumer is an important factor in the problem.

Sundry Considerations. - In the business of farming it is important to be able to borrow money on reasonable terms. In order to do this credit must be established. Credit is established largely through square dealing with neighbours and business firms for a long period of time in one locality. For this reason it is a distinct disadvantage to go from a place where one has established a good business reputation 
to a new locality. As a rule, where agriculture is the main industry, the farmer is provided with good banking facilities, and money is loaned at reasonable rates.

When those who handle and distribute products want to buy, they go to those centres where such products are raised in car-load lots, and where quality is standardised. Apple-buyers go to regions where standard varieties are raised in large quantities, and where the fruit is graded and packed in a standard manner. Buyers of hogs and cattle go where farmers make a business of growing these products on a large scale. Where only here and there a farmer tries to produce something not common to the community, there is great disadvantage in marketing.

In some localities the growing of crops has been made profitable by the establishing of marketing-associations. In Jefferson County, Kentucky, for instance, the profitable growing of Irish potatoes in competition with other potatogrowing regions is due primarily to the development of efficient marketing-associations. The growing of such products as strawberries for 


\section{ADVANTAGES GAINED}

the general market is profitable only when efficient shipping-associations are organised. Yet many opportunities occur for selecting a situation where a local market for special enterprises may be developed. There are places where a few special farm-enterprises, like dairying, trucking or poultry-raising, could be made profitable, although an attempt to develop such enterprises on a large scale would surely meet with failure.

Persons who live in a community where adequate protection of person and property by law and by custom is taken for granted, seldom realise how important such protection is in farming. In many places the raising of sheep for wool, and lambs for market, is practically impossible because it is the custom to allow dogs to run at large. Where some persons impose on the rights of neighbours, and where lawless acts occur, farms will not prosper, however advantageous may be the soil and other resources.

Where labour is scarce and wages high, other things equal, farming must be done at a disadvantage. The seriousness of labour-problems on the farm depends much on the type of farm- 
ing. Tobacco and cotton require that a large amount of cheap labour be available. The same is true of many lines of fruit and truck farming.

The advantages of a region tend to become reflected in the price of land; in other words, they are capitalised, and the man buying a site must pay a price commensurate with them. In a given locality, land having superior soil will be higher in price than land of poorer quality. A farm so near a shipping-point that the farmer may make two trips a day instead of one will have a higher price than a farm so situated that but one trip may be made. Just how much this difference will be depends on conditions which will vary in different localities. The factor of distance will be of greatest importance where products are to be hauled to market. Sometimes, as is the case with such products as peaches, strawberries, or tomatoes, the kind of product has much to do with the economic advantage of distance from shipping-point.

Importance of Good Roads.-It has been estimated that a good road will add in certain localities twenty-five per cent. to the value of a farm having connection with it. Measured in 


\section{ADVANTAGES GAINED}

terms of economic advantages alone, the amount will evidently vary with the kind of farm-enterprises, the time of year products are marketed, the climate, etc.

In regions where grazing is a major farm-enterprise, or where, as in the North Central States, cattle-feeding and hog-feeding are extensively practised, well built, hard roads are of relatively little economic advantage to a farm. This accounts largely for the fact that in some of the richest farming communities the roads during the late winter and early spring months are in a condition beyond adequate description.

In northern Iowa, in Minnesota, the Dakotas, and in much of Kansas and Nebraska, where the winter and early spring months are dry, hauling may be done during these months, when the ground is frozen to a considerable depth. In this region the road drag has proved to be an efficient implement for maintaining roads in fair condition. Because of general farm-advantages the automobile has come into use in this region, and has had a great influence in producing and maintaining good roads.

Situation a Factor of first Importance.-In this 
chapter the discussion of the problems of farm location has dwelt almost entirely on physical and economic conditions. It must be evident to the reader that much time and resources may be expended in a vain attempt to make a living, or profits, in farming, not because of a lack of knowledge of the details of growing crops, or handling the soil properly, or lack of organisation or administrative ability, but on account of a lack of specific information relative to factors involved in situation. Without the means of interpreting and measuring the physical and economic advantages of a definite location a farmer must meet his problem in a groping and unintelligent manner ; in fact in the past the development of difficult problems has forced him out of business and into new circumstances where he hoped that advantages would come to him. The farmer should be able to measure as accurately as possible the advantages and disadvantages of any particular place, and if he finds that the natural disadvantages are too great to be offset by scientific management, it will be wise for him to go elsewhere.

The writer is fully conscious of other than eco- 


\section{ADVANTAGES GAINED}

nomic advantages related to the problem of farm location, but they are fundamental in modern civilisation. The wants of a majority of people living within reach of commercial facilities are supplied indirectly through their contribution of labour, of capital, or other resources, to industrial society. This results in a competition for money which, in all commercially accessible places, is exchangeable directly for most things that people want.

Advantageous home-surroundings, school and church privileges, protection of personal and property rights, social and political opportunity, are desirable things which normal people want. The patriotic, unselfish and normally constituted man or woman will consider these among the advantages to be secured when seeking a location for a farm. 


\section{CHAPTER IV}

\section{ADVANTAGES SECURED BY CONTROL}

IN the previous chapter an attempt was made to point out and illustrate the advantages to be secured by situation. If a farmer wanted to grow wheat and had in mind economic advantages only, he would naturally seek the place where he could produce it at lowest cost, where the transportation-rates were favourable, and where a good quality of grain could be produced in order to get the best price.

The farmer may, however, secure those advantages by means of control; that is, instead of seeking a place where soil, climate, and markets seem naturally most favourable, he may, to some extent, at least, manage his affairs in a way to secure these advantages where he is. Whether a farmer should change his situation, or use means to control an unfavourable environment, is largely a question of cost.

The physical conditions related to the farm 


\section{ADVANTAGES SECURED}

which the farmer may control to a more or less extent are moisture, drainage, soil-fertility, soilerosion, and to some extent the climate. Wet land may be drained and made to produce well; arid or semi-arid land may be irrigated, or other means used to obtain sufficient moisture to produce crops desired. The tobacco-planter or truck-gardener need not necessarily wait for a favourable season to plant his crop, for he may in a large measure create favourable conditions of soil by the use of well-established and practical methods. Science has recently discovered means to control the bacterial diseases and insect-pests of plants and animals, also to secure desirable qualities in both by the process of breeding. It is important that the farmer know that means are available, and to learn in detail the process of applying these means with profit. Good management is shown in using these means with economic sense and judgment.

It is evident that these improvements and means of control require expenditure and labour, material and implements. Drainage is a permanent improvement, and will thus increase the value of the land, and interest must be 
earned on this increased value. The temporary control of moisture-conditions by such means as rolling, dragging, ploughing under cover-crops, etc., requires labour, implements and material, the cost of which must be charged to the crops.

Control by Drainage.-A system devised for a 14-acre field illustrates the usual method of drainage. Tile was laid about three feet deep and fifty to seventy-five feet apart. Table 1 is a copy of an itemised cost-statement covering materials and labour. The cost per acre of the area underlaid with tile is thus seen to be about \$28. The entire fourteen acres has been benefited by this system, however, so that the cost per acre, distributed to the fourteen acres, would be about $\$ 22$ per acre.

The cost given does not include services of an engineer to locate the lines for ditches and their depth.

TABLE 1. SHOWING ITEMISED STATEMENT OF COSTS FOR DRAINING A 14-ACRE FIELD

4000 pes. 4 in. tile per 100 feet ...... $\$ 1.90$

900 pes. 8 in. tile per 100 feet ....... 5.70

716 pes. 6 in. tile per 100 feet ........ 3.75

10 Y's $8 \times 4$ in. tile per 100 feet ...... .40

$1 \mathrm{Y} 8 \times 6$ in. tile per 100 feet $\ldots \ldots \ldots . .35$

$1 \mathrm{Y} 6 \times 4$ in. tile per 100 feet ....... .30

$\$ 76.00$

51.30

26.85

4.00

.35

.30 


\section{ADVANTAGES SECURED}

Ploughing out furrow for ditches ....

Hauling the tile ...............

$\$ 284.19$

This is a fairly typical case, and the illustration is given to point out the principles involved, and to show the farmer how to approach the drainage problem.

Such means of controlling the physical condition of the soil add a great deal to the cost per acre, and the results in production should warrant such expenditures. On the fourteen-acre tract above referred to at least seven per cent. interest should be earned on the $\$ 284.19$, the cost of the system, to cover, in addition to interest on the investment, the cost of repairs, depreciation, etc. This would amount to about $\$ 21$ a year, to be earned on the tract in addition to former profits.

In the case of many farmers it may seem impractical to purchase tile. Some of these men, however, live where stone or timber is plentiful-materials that may be used instead of tile. The following directions for using timber to drain wet land were written for the instruction of Roman farmers more than 2,000 years ago : 
If the land is wet it should be drained with trough-shaped ditches, dug three feet wide at the surface, and one foot at the bottom, and four feet deep. Blind these ditches with rock. If you have no rock, then fill them with green willow-poles braced cross-wise. If you have no poles fill them with faggots. Then dig lateral trenches, three feet deep and four feet wide, in such a way that the water will flow from the trenches into the ditches. 1

In a general way these are well-stated directions. Possibly the trenches are wider than necessary. The depth, however, is about the standard advised by drainage experts. Many farmers who have little or no cash with which to buy drainage materials have time which could not otherwise be used profitably, and could greatly increase the net income of the farm by applying labour to such permanent improvements.

Soil-erosion.-The erosion or washing away of soils is a serious problem in many localities. Surface-soils everywhere are gradually being carried away to lower levels, and under certain conditions this removal is very rapid. Sometimes a single storm will carry away one inch or more of top-soil over a large area of fertile fields, often destroying crops. While no means

1 Roman Farm Management, by a "Virginia Farmer." 


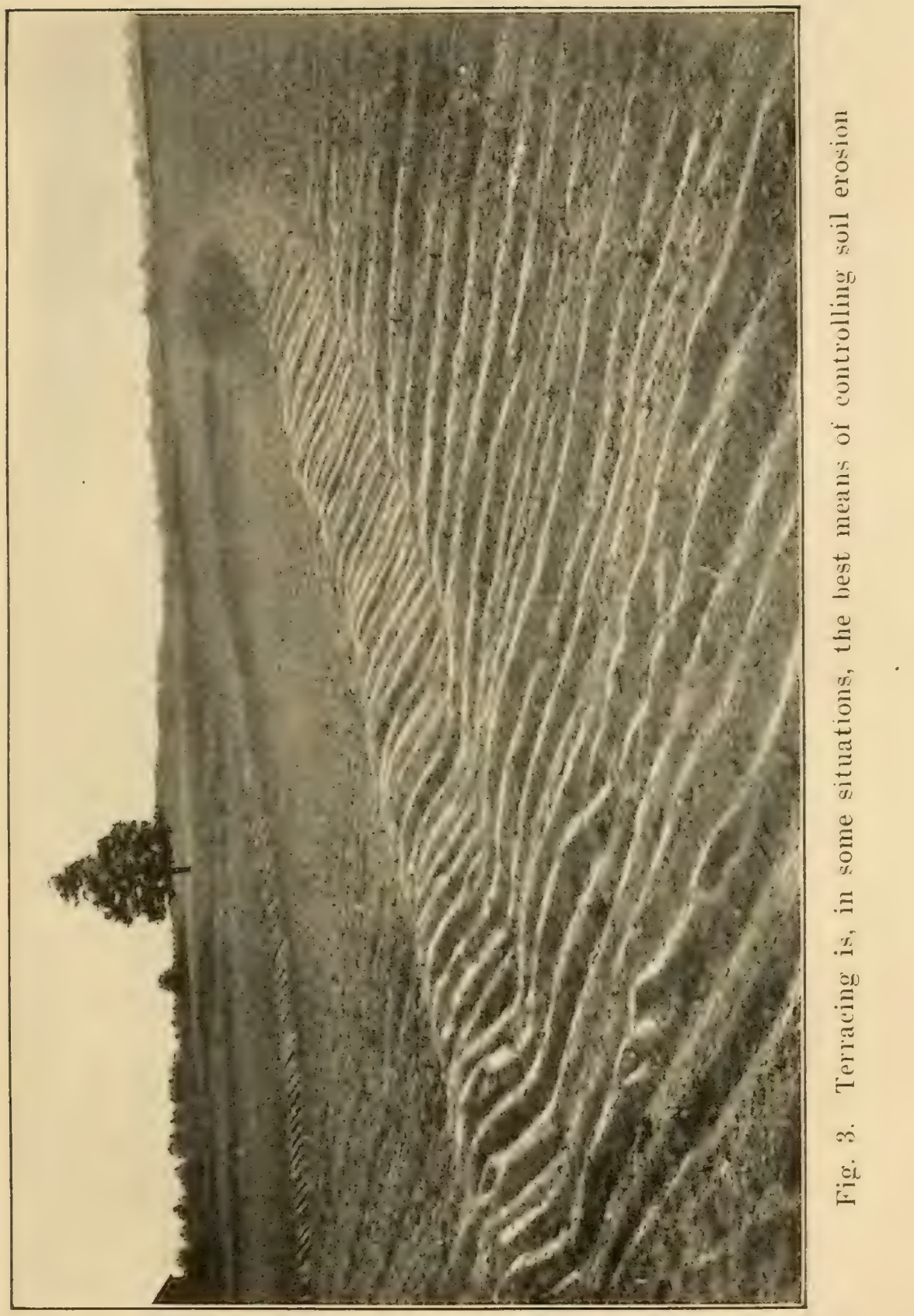





\section{ADVANTAGES SECURED}

are available by which soil-erosion may be entirely prevented, the farmer may reduce the rate of erosion to such an extent as to maintain the soil-resources of the farm.

Underground drainage as described above will greatly lessen soil-washing by allowing more water to flow away underground. Deep ploughing has been found to be a practical and inexpensive means to accomplish similar ends and in some cases subsoiling will answer. A deep layer of soil well filled with vegetable matter has been shown to retain a large amount of moisture. Such a layer of soil seems to act like a sponge, while a soil devoid of such matter runs together, and is easily taken up by water and carried away. The fact that the soils of the Southeastern and South-central States are peculiarly liable to injurious erosion is no doubt due partly to their comparatively low humuscontent.

A special means for controlling soil-erosion is terracing, a practice common in some of the Cotton States, such as South Carolina and Georgia; and to some extent throughout the region where mountain-agriculture prevails, and where soil is 
especially liable to erosion. ${ }^{1}$ This is done by contour ploughing (sometimes a scraper is used) in such a way as to leave ridges athwart the slope at certain measured distances. Between these ridges the natural erosion will tend to level up the land. Terraced land is more or less inconvenient to cultivate, and on the steeper slopes involves much expense.

Often when the soil on a field is left exposed for a comparatively long time before a crop is put on it, single furrows may be run at proper distances apart around the hill. Such furrows, properly made, will check the rapid flow of water over the surface, and distribute it gradually to lower levels without injurious effects. Such simple means cost virtually nothing when done in connection with regular necessary operations. Often a little intelligent consideration given to ways of cultivating the soil, or of driving over it with wagons, or other implements, may prevent disastrous effects. Leaving a cultivator-furrow on a slope toward the foot of a hill makes a channel for water to flow down freely; and

1 Bulletin No. 17, North Carolina Geological Survey: The Mangum Terrace, U. S. Dept. Agr. B. P. I. Circular No. 94. 


\section{ADVANTAGES SECURED}

where such furrows are three to four feet apart, between rows of corn or other cultivated plants, the amount of soil carried away may be enormous.

The formation of deep gullies is often prevented by leaving narrow strips, where they naturally occur, in forest growth, or in some perennial grass, such as bluegrass or Bermuda grass. In places where winter cereals are grown, and where such winter cover-crops as vetch and crimson clover are adapted, an effective means of conserving the soil is established in the system of farming. Old, washed-out gullies may often be inexpensively filled by placing obstructions in the ditch at intervals. Such obstructions may consist of rocks, brush, or weeds, held by stakes driven into the ground. Old farms that seemed practically ruined have been fixed up by filling gullies by the use of a plough and scraper. Such treatment costs labour, and when such a farm is to be purchased or rented the cost necessary for such work should be carefully calculated.

The methods enumerated for dealing with soilerosion problems are not subjects for specific 
farm-management investigation. It is necessary, however, for the manager of a farm to know practical methods for handling such problems, that he may consider them as items of cost in maintaining proper soil-conditions.

Injury by Wind.-In certain parts of the semiarid country of the West there have developed, during a series of dry years, what are suitably called "blown strips." The writer has in mind one in particular which developed during 191213, and almost ruined the best and most highly developed agricultural part of a county. Its extent was about forty miles long and seven miles wide. Buildings, fences, and young forest trees were buried beneath drifts of soil. Old stream-courses and gullies were filled up and changed to ridges. In fact, the topography of this whole area was materially changed in the course of two years. Most of the inhabitants were driven away, and for a time were financially ruined. The area kept spreading and encroached upon a thriving town. The business men and farmers of the community and the railroad authorities co-operating with the State agricultural college, challenged these destruc- 
tive forces of nature, and began to establish means to control them.

The lister, an implement used in that region for planting corn and forage-crops, proved to be adapted for the purpose. With this implement a trench twelve to sixteen inches deep may be made, in the bottom of which field-corn, Kaffircorn, or other similar forage-grain may be planted. A chance rain will be likely to start these plants growing in such trenches. They are drought resisting plants, and when started will grow very fast. The trenches with ridges on each side and the forage plants, if they chance to grow, will check the loose dirt, which moves swiftly over the hardened surface in the stiff winds that frequently occur. The winds scatter the seed of native plants and weeds constantly. The soil held in place sufficiently by the trenches and the growing plants, enables the native vegetation to get started. In a few months thousands of acres were recovered with native vegetation, and as far as the eye could reach these furrows and rows of forage, about four rods apart, could be seen. In a few years such a blown strip will be repopulated, and it is hoped 
84 FARM MANAGEMENT

the farmers then will have learned an important lesson in the management of dry-land soils.

Control by Irrigation.-The irrigation of dry lands, and even irrigation for special crops in more humid climates, are problems of local interest to farmers. Irrigation has long been practised as a means of controlling the watersupply in the soil. Under most circumstances it is very expensive, and the expenditure would not be justified except in cases where the problem has been carefully considered. Millions of dollars have been lost in farm investments because the location of an irrigation project had not been considered from the point of view of crops that could be profitably grown and marketed. A proposed scheme, considered simply from the standpoint of increased production, may look feasible, good, and interesting; but if the stuff produced is in the wrong place to be disposed of, if the climatic factor has not been looked into, if irrigation develops injurious effects in the soil (such as alkali deposits), tho project is more than likely to end in disaster. Promoters of irrigation-schemes in their literature do not throw light on the problem by relat- 
ing the history of failures as well as the history of successes.

Other Means of Mloisture-control.-The soilmulch theory is widely known as a means of regulating and conserving soil-moisture. Another theory is that shallow cultivation, by preventing the growth of weeds, which take moisture from the soil, indirectly regulates and conserves moisture for the growing plants. Probably cultivation conserves moisture both by preventing evaporation and also by preventing weed-growth, depending on soil and climate conditions at the time the cultivating is done.

Experienced and intelligent farmers in a locality know pretty definitely the amount of labour, power, and material that may advantageously be expended in maintaining the soil in proper condition. Such farmers can give intelligent reasons for their local way of rolling, dragging, disking, and cultivating the soil. They will perform such operations only when and in such a manner as the conditions at the time require. A practical and intelligent farmer will not have decided on an absolute standard depth of ploughing for all conditions, a 
definite number of times to cultivate his corn, or to roll the land. He performs these operations to accomplish certain definite results, and will not wisely do more work than is needed to accomplish the results wanted. If he knows the cost in labour and power of each operation, besides knowing its purpose, he can calculate more intelligently the line of greatest advantage when required to meet a problem.

Many writers and lecturers on farm-problems, and even some bulletins that presume to be scientifically authoritative, have wrongly advised farmers that any method for handling the soil, or of treating a crop which results in greater yield, is a method or treatment worth while for any farmer to follow. Also it is often taken as granted that some method or practice which has proved profitable to a particular farmer in a certain locality, or has been demonstrated to be profitable on an experimental farm, should be a profitable method or practice for all in a given locality to follow. This may be illustrated by the following table, which summarises the work put on corn land by a farmer who 
thought he was economising by never using a plough on his farm:

\section{Estimated \\ man- \\ days per acre}

Disk, 12 times .............. 1.44

Harrow, 2 times ........... .10

Plant, 1 time ................ 10

Harrow, 12 times ............ $\quad .60$

Cultivate, 13 times .......... 1.82

Husk, 1 time ............ 1.00

Totals ............ 5.06
Estimated

horse-

days per aore

5.30

.40

.20

2.40

3.64

2.00

14.00

As a measure of his success this farmer states that during a dry year, when these operations were performed, his corn stayed green while that of his neighbours' who used the plough was "burned" and badly damaged by drought. There is a failure here to measure comparative results in actual yield or net returns for labour expended. This farmer expended about twice the labour the average farmer expends in that region, or at least $\$ 10$ more per acre. A yield of 25 to 30 bushels more than the yield obtained by the ordinary methods would have to be secured to justify the extra expense of labour, and it may be doubted if this was done on this farm.

Soil fertility may be controlled by the use of 
commercial fertiliser and lime, turning under green crops, by stock enterprises or by rotation of crops.

Profit from Fertilising.-Eastern lands are not only as a rule low in natural fertility, but the tillable areas are scattered here and there in irregular patches, making it difficult and often impossible to farm advantageously tracts of land suitable in size and shape. Partly for these reasons, increased production per man can be secured more advantageously by increasing the yield per acre by means of some commercial fertiliser than by increasing the size of area farmed, or by the use of implements of larger capacity. The practise of putting lime on the soil is also common in this region. Lime for all practical purposes may be classed as one form of commercial fertiliser, since its presence in the soil is essential to the normal development of most important farm crops.

In the previous chapter it was shown that one of the main advantages secured by liming the soil is that of getting vigorous stands of such legumes as red clover, alsyke clover, sweet clover, and alfalfa. These legumes store nitro- 
gen in the soil, and put the subsoil in good physical condition for growing crops; they also furnish vegetable matter for the soil from the roots and stems. It is well known, however, that many plants will thrive pretty well in sour soils, and that such soils may be made to yield more productively by other means than by liming. While corn makes larger yields as a result of liming the soil, largely no doubt on account of clover or other legumes benefited by lime, many instances are on record where yields on sour soils have been doubled by other means than liming. The results obtained by boys' cornclubs on all sorts of soils are evidences of possibilities. Profitable farms are found on which soils giving an acid reaction make yields as high as fifty bushels of corn and thirty bushels of wheat during favourable years.

\section{Fertility Promoted by Mixed Farming.-The} practise of a prosperous farmer in such circumstances will illustrate how fertility may be controlled by a combination of farm-enterprises. All crops except wheat are fed to hogs and steers. On a 1000 -acre farm about 300 steers and 500 to 600 hogs are fattened and sold each 
year. Figuring on the basis of the farm-value of the crops fed to stock, little if any profit comes from the stock directly, but stock-feeding, employed as a means of increasing production on the farm, pays the farmer, since by such means (which pays its way and a little more), the crop-production is increased above the average. By such means the farmer does not get a much better price for his corn, but by increasing yields he decreases the cost of production per bushel, and thus gets increased profits.

The test of any device or scheme for building up the soil, or for increasing production in any other way, must be tested on the basis of cost of production. Such problems are strictly farm-management problems; and unless the farmer can test the schemes and devices offered him, or can get the services of some one to do it for him, he runs great risk of financial loss.

In some parts of the corn-belt, where the feeding of steers has been profitable, the fertility of the soil has been greatly increased without the use of commercial fertilisers. A common fieldrotation is corn, corn, oats and clover, furnishing equal areas of oats and clover, and twice the 


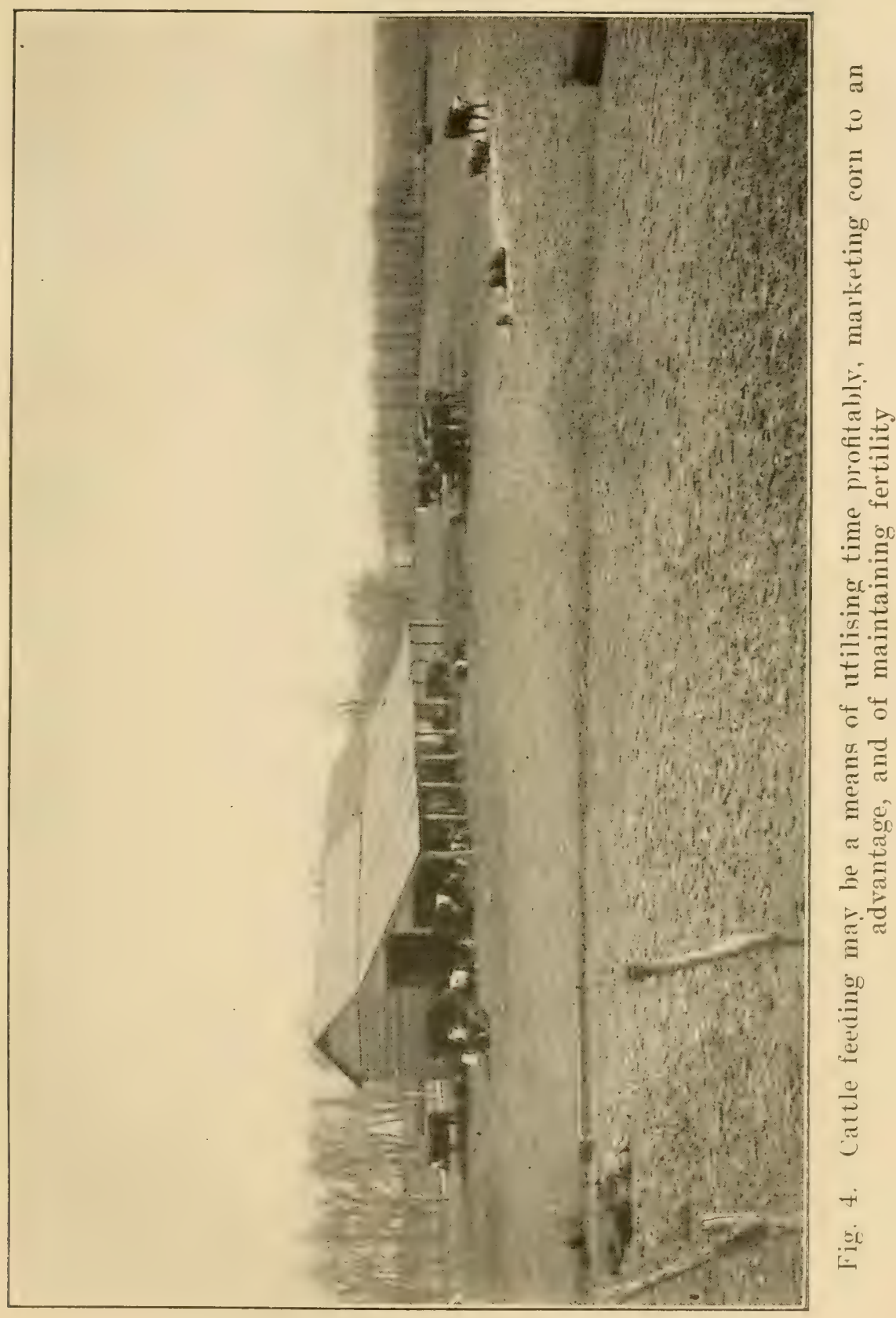





\section{ADVANTAGES SECURED}

area of each of corn. On a 160-acre farm about fifty head of cattle may be fed. The manure from these, and from the several horses kept, will allow about forty acres to be covered each year by means of the manure spreader. This, with the clover turned under, has greatly increased fertility in many sections.

A study of the agriculture of Japan and China reveals the fact that in these countries, where the people have been forced to a highly developed system of intensive agriculture, soil fertility has been maintained for many hundreds of years without the use of any chemical fertiliser, by applying to the soil every decomposable substance within reach-weeds, leaves, straw, and animal and human excrement. Isolated instances showing the same possibility in our own country have been discovered, and some of them have been put on record. ${ }^{1}$

Through the use of lime and commercial fertilisers thousands of farmers in the eastern half of the United States have been able to live and prosper on farms which twenty-five to thirty years ago were unable to support families prop-

1 See Farmers' Bulletin 519. 
erly. Under the conditions prevailing here the most economical means of building up and maintaining the fertility on farms is to use lime and fertilisers; but the most satisfactory and permanent results from the use of these can be obtained only as vegetable matter or humus is constantly supplied in the soil. On most eastern farms this important ingredient can be supplied most economically by turning under crops grown for the purpose, or by pasturing off crops with stock. This leaves the manure of animals widely distributed on the fields, and much of the vegetable matter is tramped down and into the soil. The crops most commonly used for turning under and pasturing off are rye and cowpeas-two crops especially adapted to "sour" soils. Crimson clover and hairy vetch are adapted to the same purpose on sandy soils, wherever moisture is sufficient, and where the surface is protected by snow in winter.

\section{Crops Turned Under.-Turning under crops} adds a great deal to the expense of maintaining fertility. If the seed, labour, and rental charges are considered on the basis of a year's rent, the cost would range between $\$ 5$ and $\$ 12$ per acre. 
In the more southern climates the above-mentioned crops may be grown as winter covercrops, or catch-crops, during the growing season, and in connection with other tillage operations the expense is greatly lessened. These are problems of farm-organisation to be considered in another chapter.

The cost of maintaining soil-fertility by the use of lime, fertiliser and crops turned under will not be far from $\$ 5$ to $\$ 6$ per acre per year at standard prices for materials and labour. On farms the organisation of which will allow the labour to be done at times when it cannot be employed in productive work, the cost may be considerably lowered. Some of the best agricultural lands, on which no lime or commercial fertiliser is needed, may be rented for $\$ 5$ to $\$ 8$ an acre. Hence, unless the yields on specially treated lands were equal to or above those obtained in naturally fertile areas, or unless much higher average prices may be obtained for products, the value of the land would need to be very low in order to allow profitable general farming to be carried on. The raising of special fruit and truck crops would of course 
have to be considered on an entirely different basis.

Spraying.-One of the most striking illustrations of the value of the scientific investigation of agricultural problems, and of putting into the hands of farmers practical means of control, is that of spraying for fungus diseases and insect pests of trees. Scientific investigators have not only worked on the problems of how to accomplish results, but on the economic problem also, by discovering materials and devising methods that make the means of control practical and profitable. The control of hog cholera by means of inoculation is another remarkable illustration of the solution of a serious and important farm problem.

All such means of control require the time of men and a team or teams; and special equipment is also necessary, so the farmer should estimate carefully the cost of such means before applying them under his particular conditions. If the farmer had to employ expert services at high prices in treating his crops by spraying, or if the treating of hogs properly with serum could be done only by the skilled veterinarian, the 
costs would in most cases be too high relative to prices of products. On the other hand, as the methods for such treatment can be handled skilfully by farmers themselves, the means may be economically justified.

The cost of spraying peach-trees, for instance, will vary from five to ten cents per tree per year during the bearing stage. The results in yield and quality, however, are large for the cost of treatment. If the yield is sufficiently increased, the cost of production may be covered. If the quality is improved the price is higher.

Many other illustrations might be given showing the progress in scientific agriculture through the development of means of control which many farmers have found practical and economically useful.

Plant-breeding.-In connection with problems of control may be mentioned the wonderful progress made in securing advantages through plant-breeding. Many crops rapidly adapt themselves to conditions of climate and soil. By means of controlling the breeding processes, certain desired characteristics may be emphasised and perpetuated in both plants and ani- 
mals. Not farther back than 1875 the ordinary varieties of dent field-corn would not mature in northwestern Iowa. In South Dakota, as late as 1890 , only the flint varieties were seen on the few fields growing it. Not until about 1887 did red clover prove a valuable crop in northwestern Iowa and in Minnesota, probably because of lack of inoculation in the soil. Now these districts are included in the great corn-belt of the Northcentral States.

West of the Missouri river, alfalfa will grow when moisture is available, without special coaxing. In the East, where "sour" soils prevail, and inoculation is lacking, the growing of alfalfa involves technical skill.

It is the prevailing idea of those who have been educated to believe that the measure of good farming is the product per acre derived from the soil, that the American farmer is much behind the modern European farmer in the skilful utilisation of his resources. The truth is that as our country is very extensive in area, and all stages of agricultural development are found within our borders, any valid comparison must be made with similar conditions in view. In 


\section{ADVANTAGES SECURED}

large areas of our country, especially in isolated mountain regions, thickly populated, the most primitive and the rudest methods are used. In the most fertile and extensive agricultural sections of our country the farmers have developed along lines of extensive agriculture where labour-saving devices have supplanted hand labour to a large extent. There may be found also in the United States localities where the most intensive type of agriculture is being carried on, and where the methods applied are highly technical and in accordance with the latest achievements of agricultural science.

The typical American farmer is not satisfied with day-wages. He expects a farm-income equal to that of the retail grocer, the banker, the doctor, or the lawyer. To maintain such incomes the farmer must develop skill as a business-man, as well as develop technical skill along his own lines. 


\section{CHAPTER V}

\section{FARM CROP PROBLEMS}

AN extremely important problem of the farmer is that of employing his time profitably; and in order to do this he should consider such crops only as can be economically grown. In the succeeding chapter enterprises in live stock will be discussed from the same standpoint. Whatever enterprises the farmer undertakes should be so related to his farm-organisation that an intelligent reason can be given for selecting them.

Crops on the farm require definite operations to be performed at certain seasons of the year in order to promote their growth and maturity and to harvest and market them. Such operations require labour, power, machinery and materials. In many cases manufacturing processes are employed on the farm, such as canning, making butter, curing meats. These are in harmony 
with good management when the time or season spent in doing them could not be more profitably employed. As a rule, crop and livestock enterprises should not be selected on the basis of the temporary profitableness of the individual crop, but rather on the basis of a system that has proved successful in the locality, or elsewhere in a similar environment. Those enterprises that have stood the test of conditions in a locality for a long series of years may be safely depended upon and should form the basis of farmorganisation in that locality.

Factors of Labor and Time.-The crop-specialist or livestock-specialist makes some single enterprise the thing of primary importance, and tells how to handle it in a way to produce maximum quantity or suitable quality. This is fundamentally important, of course; but the farmmanager is concerned with such means primarily from the standpoint of cost. The most important cost-factor in most crop-enterprises is labour, hence it is important to know the seasons within which the various operations must be done and the amount of work required. It is clear then that the labour-requirements on a 
farm should be measured in such a way as to enable the farmer to estimate intelligently the advantages to accrue, considering the most profitable use of the available time.

In certain regions the net income per acre on tobacco is much larger than that on wheat, corn or clover. Why should not the farmer raise this crop alone? The main reason is that the labour-requirement of the crop is such that the farmer can not put in his time continuously. If this crop is the most profitable one for his locality, he will put in such time as is available for it; the time that is not available he will wisely employ on some other crop, which may not give as high returns per acre as does the tobacco, but which will enable him to employ certain periods more advantageously than could be done in any other way. He may find also that the cultivation of a tobacco-crop, in addition to making the time during certain seasons most valuable, puts the land in good physical condition for some crop that may succeed it. Wheat, for instance, may make five to eight bushels more per acre after tobacco than after corn. This fact may further increase the util- 
ity of tobacco as a crop, and make corn relatively of less value in the cropping-system. Still, corn may be a profitable crop to grow in such a region on account of its fitting into the system.

It is profitable under certain conditions to confine farming operations to a single crop, thus leaving a large part of the time available for crop growing unused. Thus in some localities it has been profitable to spend time almost entirely on wheat; elsewhere cotton may be grown as the only money-crop. In general profits may be increased by intelligently considering how to make use of waste time.

Long and Short Seasons.-In the latitude of Iowa the seasons in which the various required operations may be done are short, as compared with similar operating seasons in southwestern Kentucky or northwestern Tennessee. Here ploughing may be done at favourable times during the entire fall and winter months, and the planting season may continue from about March 15 to the end of June. On the other hand, in central Iowa, field-work during December and the three first months of the year is not per- 
mitted. The planting-period of corn is limited to about fifteen days in May. The growingperiod of this crop in this latitude is limited to about 120 days, while corn-growers in Kentucky and Tennessee may count on about 190 days in which to mature a crop. There the farmer often puts out an early crop and a late crop, planting tobacco between the two seasons, and thus has a better chance to benefit by rains at critical times during July and August. The summers in those States are normally dry and hot, so that this crop runs a greater risk of being cut short on this account than on any other. This is also true of the semi-arid regions of the West. In the northern corn-belt moisture deficiency, while to a certain extent a menace, does not as a rule endanger this crop. In the north the seasons for doing more than the preparative and planting operations are short as compared with similar seasons in the more southern climate. This is doubtless one of the reasons why farmers in the northern corn-belt have been quick to take advantage of the use of labour-saving farm-machinery. Here four- and six-horse teams, with wide-cut implements, do the work on 
many farms of only 160 to 220 acres. The elevator which unloads a load of grain in ten minutes, without manual labour, saves the time and strength of the corn-husker so that he is able easily to crib 80 to 100 bushels per day, whereas formerly he did but 50 to 75 bushels per day. In these regions crops grow more rapidly during the growing season than in more southern and dryer summer climates. Consequently, to accomplish the work required by the same area of crop, it must be done more rapidly. For this reason there are wide gaps between the operating seasons, in which no productive work may be done on the crops; and where such conditions prevail diversification in a way to give continuous work, and to distribute it as evenly as possible, becomes an important matter. Diversification is of special importance in such a region when land-values become high. Some basic rotation in managing the crop-areas is also specially important where the growing-season is short. Hence on the better-organised farms there we find fields of approximately equal size, and yielding such a combination of crops as corn first year, corn second year, then oats and clover. 


\section{Tobacco as a Time-saving Crop.-Tobacco is a} crop that utilises time advantageously and well illustrates adaptability to soil, climatic and labour conditions. It furnishes almost continuous work throughout the year, a fact of great economic significance where tobacco is a major cropenterprise. It requires not only field-work on the farm, but work indoors, such as firing, bulking, stripping, and grading. However, the time when this work may be done, even indoors, is limited by the weather. Tobacco must be handled when moisture-conditions are right.

Even marketing cannot be done during cold, dry, crisp days. The growing and handling tobacco in a way to make it of high marketable value requires undoubtedly as great skill as any known general farm-crop. In order to handle it properly without costly instruments to determine leaf-quality, moisture-content, etc., the worliman must be raised in the business. The negro labourers who do most of this work in the South become very skilful in the intricate details of tobacco-handling.

Tobacco resists a drought remarkably well. The plant may be set out the latter part of May or the first weeks of June, when the season hap- 


\section{FARM CROP PROBLEMS}

pens to be propitious. Even though rain of any importance does not occur for a month or six weeks the plant will remain almost dormant until rain comes, when it will shoot forward rapidly; and, if good rains occur, by the latter part of July or the first part of August there will be a fair chance for a normal crop. The quality under such conditions will suffer, but the farmer is virtually sure to be paid for his labour.

Another important fact relative to the tobacco-crop is that it is peculiarly sensitive to the quality of the soil and to climatic conditions. These conditions seem to have been a factor in developing certain qualities which are esteemed by users. The flavour created by the firing process becomes an established quality, and this influences the market demand. Thus the darktobacco district in Kentucky and Tennessee has practically a monopoly on this quality of tobacco. Attempts to share this market in other localities, having different climatic and soil conditions, have very generally failed. The Burley varieties, which hold a market so successfully in the bluegrass region of Kentucky, and along the Ohio River into West Virginia, illustrate how a 
crop may become established in such a way as to dominate a market. The Burley varieties have not been marketable when grown in the dark-tobacco district, although the price for this variety averages higher than does the price of the dark tobacco.

These physical facts relative to the tobaccocrop help to explain its dominance in a section that has played so important a part in the economic and political development of the United States. Notwithstanding the fact that other enterprises are competing successfully in the South-central States, it is still the poor man's crop, because there are fewer chances of failure in growing it than any other, and because it gives a farmer productive work at home with his family during almost the entire year. Similarly, the farmer who has organised a larger business clings to tobacco because the growing of this crop is of fundamental importance relative to the employment of labour on the farm.

As has been pointed out, the negro labourer brought up in that country knows the art of growing and handling tobacco. He commands good wages as day-labourer or as cropper, be- 


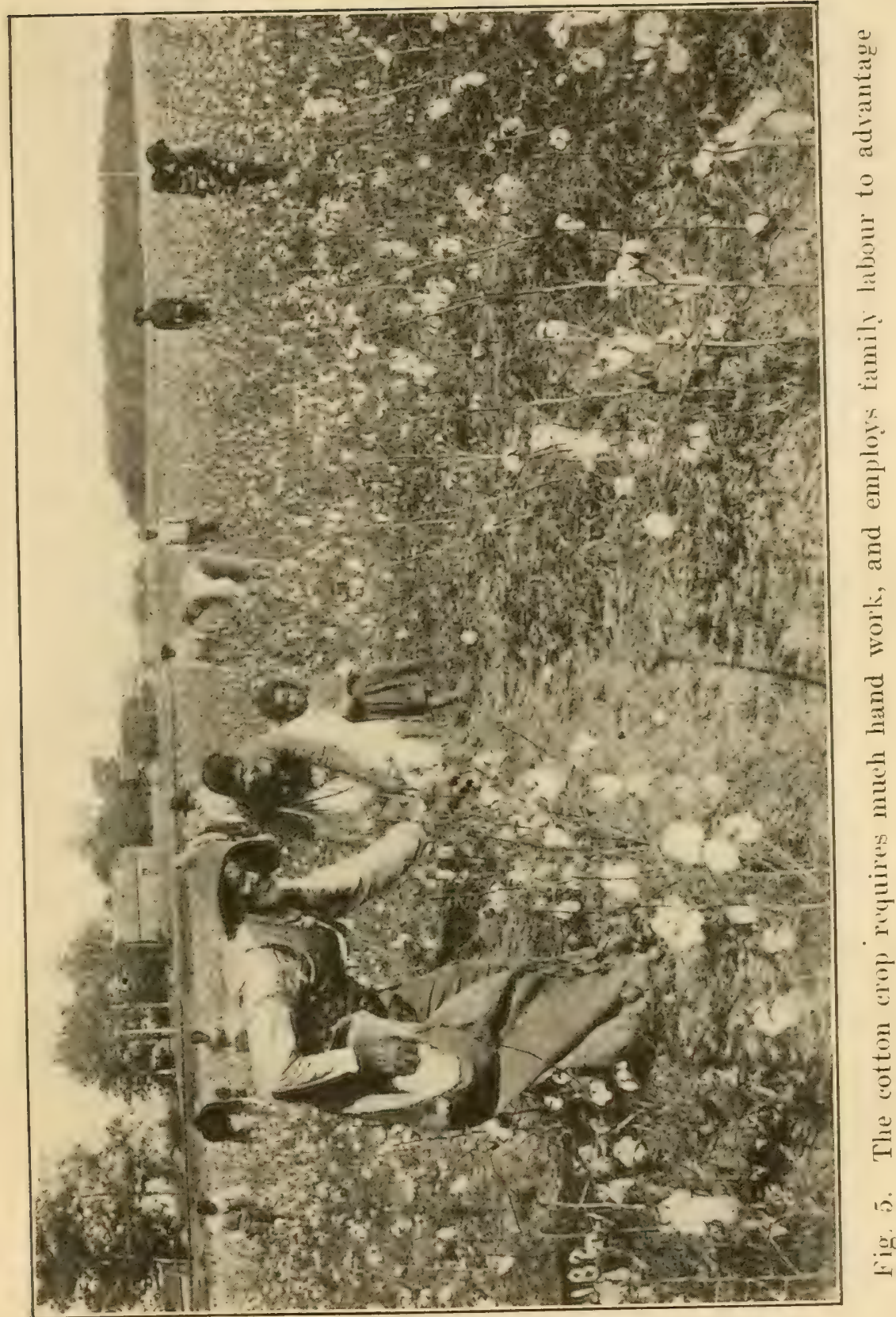



sides being provided with a cottage to live in, fuel, a garden for his family, sometimes a cow to milk, and other perquisites. Such opportunities to secure a living for a family, and to rise above the station of the ordinary farm-labourer makes available a supply of labour for general farm-work and housework. Cotton is a crop that will employ profitably the labour of men, women and children, but not so continuously throughout the year as does tobacco.

Tobacco and cotton have market-advantages that no other crop-enterprises of equal magnitude in the country have. When properly grown and prepared for the market, they have the peculiar advantage that they are readily taken as collateral by banks and loan-agencies for the advancement of money. This advantage, however, has not proved successful in promoting the general economic welfare of financially weak citizens in the South.

It has not been customary to consider cropproblems from the standpoint just outlined. How to prepare the soil, how to fertilise, what varieties to grow, when to plant, whether to sell the crop directly, or to feed it, have been the 
important problems. When the farmer's thinking is directed also to the principles which have been presented in this chapter, he should be able to make farming more profitable.

A farmer who grows tobacco or cotton has as a rule been fairly certain of wages for himself and children, and when he is especially hard up, or when unforeseen disaster occurs, such as sickness, crop-failure, etc., he can get money advanced on a future crop. The farmer who depends on corn, wheat, hay and livestock must as a rule, carry his own risks. He has less chance of making himself a debtor to capital, and for many reasons this condition is an advantage. Under proper business organisation the availability of a crop for credit should be an advantage. Many other crops have dominated the agriculture of a region in a greater or less degree. Tobacco and cotton are discussed in so much detail because they have been exceptionally important in this respect.

Considerations of Time.-The agronomist may often be puzzled when the farmer is slow, or refuses to grow and handle crops according to methods that obviously will produce larger 
yields or better quality. The business-man who has given money for a prize-fund to stimulate larger production through corn-clubs, often accuses the farmer of stupidity because he does not accept the methods which the boys have demonstrated to be so efficient in producing yields. A study enabling us to measure the time actually available for field-work, and the utilisation of this time by a system of crops, will often explain the farmer's attitude toward his instructors. In growing several crops on a farm and handling two or more stock-enterprises which also require time, the farmer must consider the time spent on the system as a whole. He may think it wise to cut out a crop or stockenterprise which may allow more work to be put on other crops. He would no doubt gladly do this if it could be clearly demonstrated that his labour-income could thereby be increased. Instead, however, he might conclude that it was wise to spend this time in cultivating more land. Knowing the standard labour-requirements of the several crops adapted to his region, and the standard available time he can spend in fieldwork as determined by his soil and climate, he 
can more intelligently decide on methods than can a stranger; and the expert on any special agricultural subject should thus measure the economic value to the farm of his "discovery," or of his method. The farmer, on the other hand, may easily undervalue the work of the scientific investigator on special agricultural subjects. Also, there is danger that the student who studies farming from the point of view of management may grow into the habit of overlooking the fundamental importance of the scientific investigation of special problems relating to soil, crops and other enterprises on the farm. Such investigations, resulting in knowledge which puts into the hands of the farmer more efficient means of control, are the basis of progress in agriculture.

The spraying of various plants with poisonous materials, the kinds and the amounts of fertilisers for improving the soil, and the quality of the products, new methods of cultivating and handling crops-all have become a part of the established practise of the farmer, and such scientific innovations have increased the farmer's income. These new practises increase 


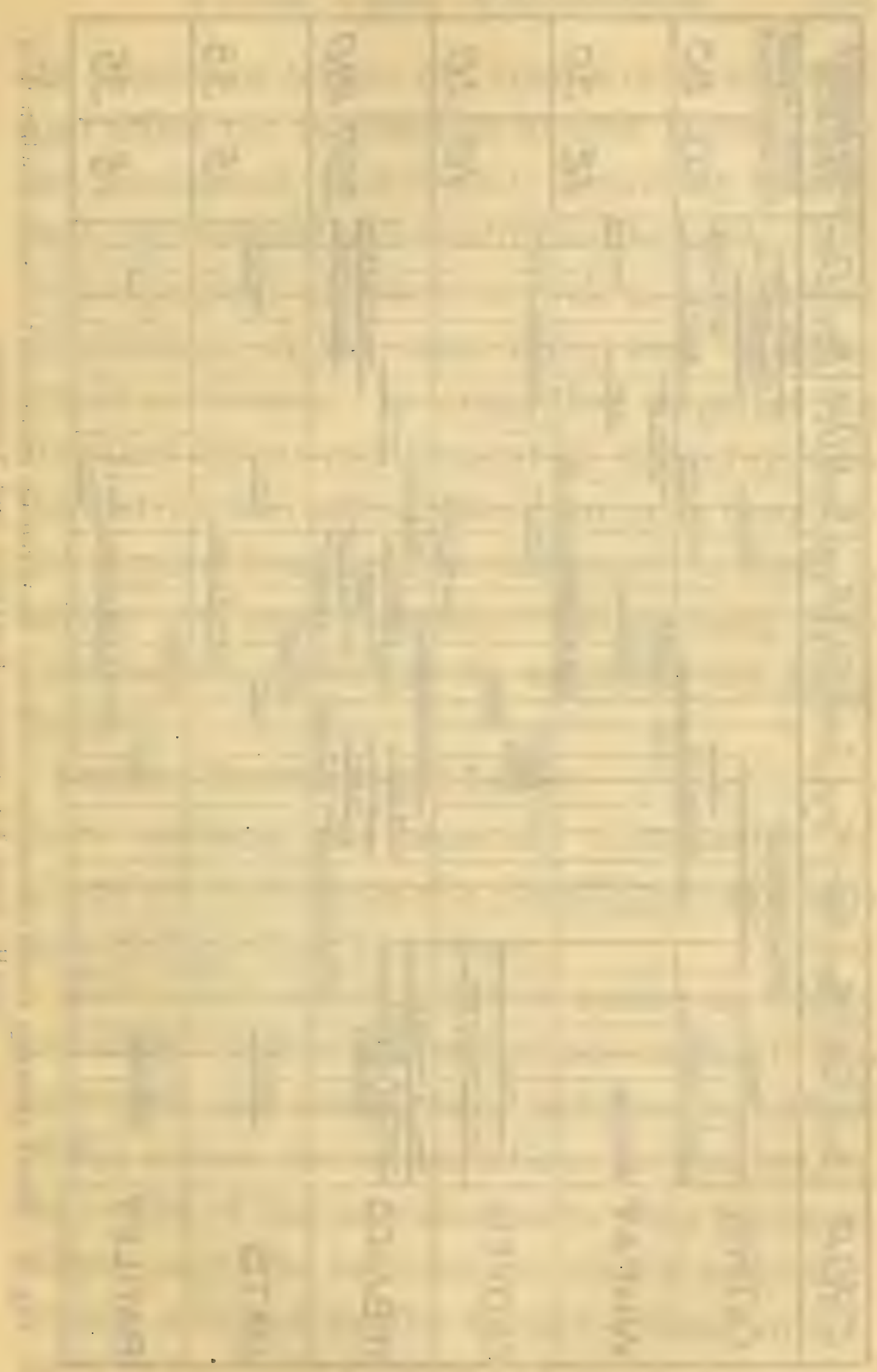




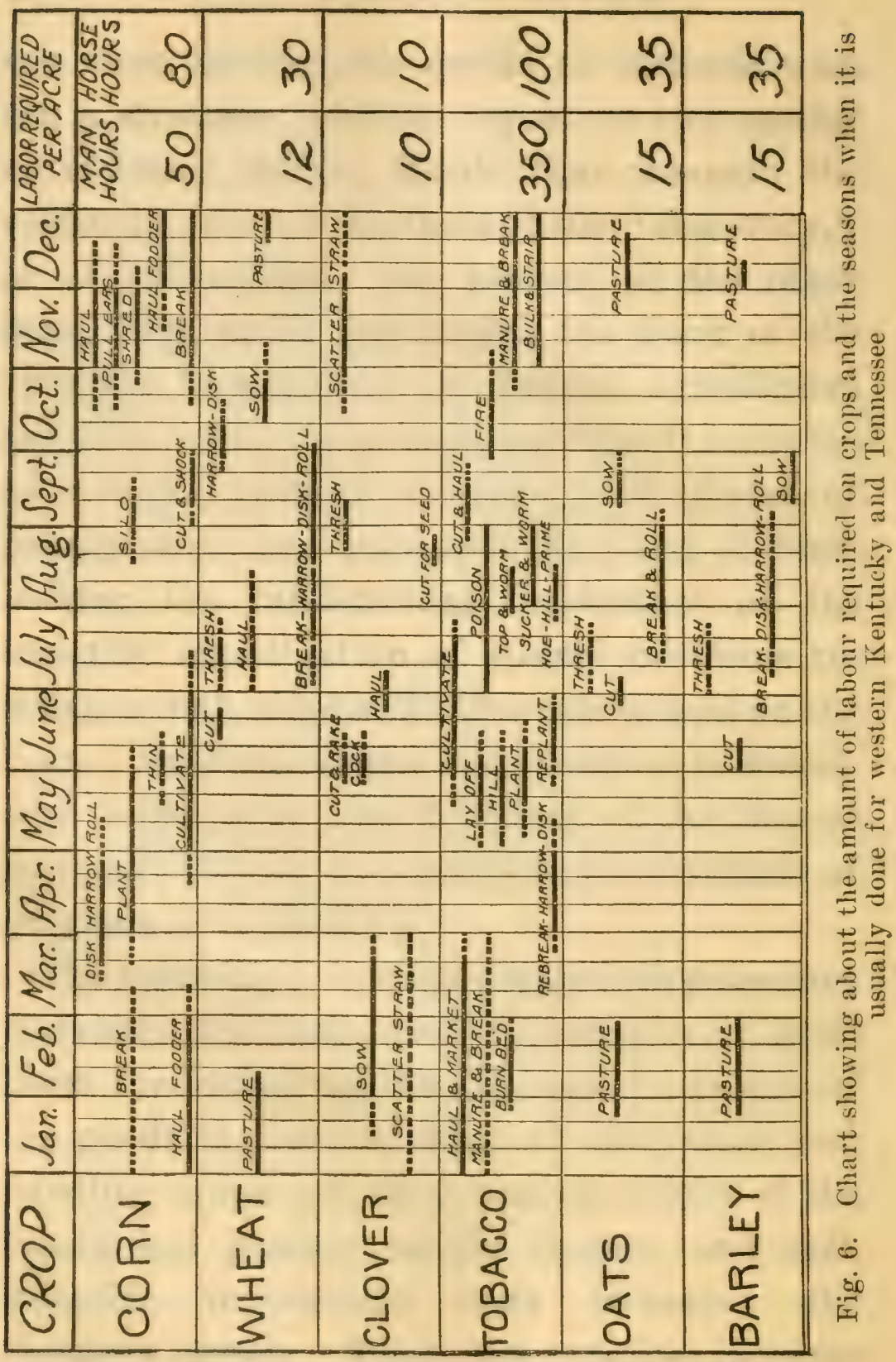




\section{FARM CROP PROBLEMS}

the amount of labour put upon a crop, and may also affect the distribution of such labour. As has been noted, each locality according to latitude, altitude and soil-conditions, demands a different amount of labour as well as a different distribution on the same crop, such as corn, wheat or tobacco. In order then to get at the standard labour-requirement of each crop, and the distribution of the labour put upon them for any typical locality, it is necessary to make a survey of such locality, taking such records as are necessary to establish the facts wanted.

Seasonal Distribution of Labour.- Figure 5 is a chart showing the seasonal distribution of labour on crops grown in the altitude and latitude of Nashville, Tennessee.

Heavy lines show limits of season as determined by the average experience on the farms surveyed; the dotted lines indicate variations of the season due to variations in weather, to the notion of the individual as to when the operations ought to be done, or to the croppingsystem adopted by the farmer. Some operations on crops are confined to very short seasons, 
and the beginning and ending of the season does not vary much from year to year. These operations are usually connected with the maturing period of crops. Wheat, for instance, is usually ripe by June 12 in the latitude of southern Kentucky, and in about ten days all wheat is cut. Barley is cut ten days previous, and oats follow wheat. These operations can not be put off in this section since the wheat will not stand up. In more arid regions, wheat develops a stiff straw, allowing a longer period of harvesting. Corn and tobacco, and other inter-tilled crops, must be cultivated frequently during the first part of this growing-period, in order to prevent the injurious effect of weeds and to keep the soil in proper condition for the best development of the plant. Tobacco, like wheat, must be harvested when ripe. When corn is cut and put in shock it too must receive attention at the proper time. Husking or pulling the ears, however, may be done in a longer season, and these operations are often put off when necessary work is crowding.

The number of operations required on a given crop varies with individual farmers, who base 
their judgment on the soil, weather-conditions, previous crops and succeeding crops. Thus a wheat crop following corn or tobacco usually receives about three operations before cutting, while in the same region, when summer fallowing is done, five or six operations may produce profitable results. Often a crop of wheat may be drilled into a clean tobacco-field without any previous preparation.

The amount of time a man and team may put on a crop does not indicate what he may accomplish. Some men with a team will accomplish more than others. It depends on the man, and the team, and the soil. Heavy teams, will, of course, accomplish more than light ones. An energetic man, and one who is alert to take advantage of favourable weather and soil-conditions, will accomplish more than will the careless, indifferent man. It is thus evident that the number of operations on a given crop will vary on farms in the same locality, and will vary from year to year on the same farm. Also, the conditions of the soil, the energy of the men employed, the shape of the fields, and many other facts of more or less importance influence the 
amount of time used in producing crops; but it is important to have standards for measuring the labour costs of various crops.

Labour and Power Units.-A day spent in performing some farm operation may be called a labour unit. A day's use of a horse or equivalent may be called a power unit. If the labour or power is applied directly on some enterprise, such as a corn-crop, or on dairy cows, the units may be termed productive labour units and productive power units.

TABLE 2

SHOWING FARM OPERATIONS, LABOR AND POWER UNITS ON A POTATO CROP

\begin{tabular}{|c|c|c|c|}
\hline Operations & Number & $\begin{array}{c}\text { Labour units } \\
\text { per acre }\end{array} \mid$ & $\begin{array}{c}\text { Power units } \\
\text { per acre }\end{array}$ \\
\hline 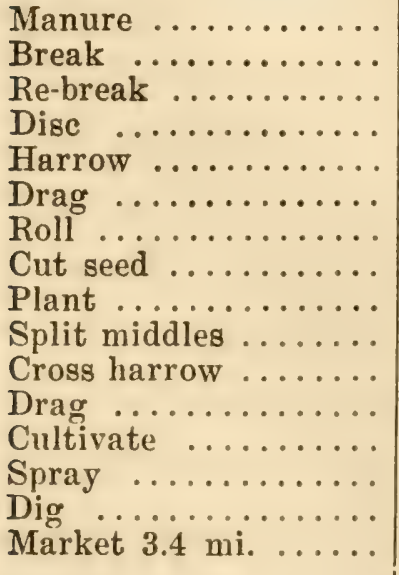 & $\begin{array}{l}1 \\
1 \\
1 \\
2 \\
1 \\
1 \\
1 \\
1 \\
1 \\
1 \\
1 \\
1 \\
3 \\
3 \\
1 \\
1\end{array}$ & $\begin{array}{l}1.00 \\
0.40 \\
0.40 \\
0.33 \\
0.11 \\
0.11 \\
0.07 \\
1.00 \\
0.25 \\
0.16 \\
0.11 \\
0.11 \\
0.54 \\
0.07 \\
2.20 \\
.83\end{array}$ & $\begin{array}{l}2.00 \\
1.20 \\
1.20 \\
1.00 \\
0.22 \\
0.22 \\
0.14 \\
0.00 \\
0.50 \\
0.33 \\
0.22 \\
0.22 \\
1.08 \\
0.07 \\
1.00 \\
1.66\end{array}$ \\
\hline Totals per acre .... & - & 69 & 11.06 \\
\hline
\end{tabular}




\section{FARM CROP PROBLEMS}

Table 2 gives the standard, productive labour and power units required on a potato-crop in the lower Ohio Valley. Here the cost of a labour unit is about $\$ 1.25$, which is the same thing as saying $\$ 1.25$ per day. The cost of a power unit is the same as the cost of a mule or horse per day, in this region $\$ 1.00$ per day. Thus the total labour-cost of the crop may be readily calculated. In this case it is about $\$ 20.00$ per acre. The other costs are standard, which, added to the charges for labour and power, give the total cost of the crop.

TABLE 3

COST IN LABOUR UNITS AND POWER UNITS APPLIED TO SEVERAL STANDARD CROPS IN

DIFFERENT LOCALITIES

\begin{tabular}{|c|c|c|c|}
\hline Crop & Locality & $\begin{array}{l}\text { Labour units } \\
\text { per acre }\end{array}$ & $\begin{array}{l}\text { Power units } \\
\text { per acre }\end{array}$ \\
\hline Corn & Kentucky & 4.00 & 4.50 \\
\hline Winter wheat ... & 66 & 1.00 & 2.00 \\
\hline Tobacco ........ & "6 & 35.00 & 14.00 \\
\hline Market onions... & 6 & 22.00 & 14.00 \\
\hline Onion sets ...... & "6 & 36.00 & 14.00 \\
\hline Sweet potatoes . & " & 15.00 & 8.00 \\
\hline Cotton ......... & Ga. and S. Car. & 11.18 & 5.00 \\
\hline Oats ..... & 6 & 1.75 & 2.29 \\
\hline Corn .......... & "6 & 4.10 & 3.02 \\
\hline Cowpea hay..... & 66 & 1.75 & 1.61 \\
\hline Corn ........ & Iowa & 2.60 & 6.00 \\
\hline Oats .... & " & 1.50 & 2.22 \\
\hline Clover ........ & " & 1.20 & 1.10 \\
\hline
\end{tabular}

Note.-These figures are based on a few studies made in specific localities and are not to be taken as averages or as applying to all sections. The table is given simply as an illustration of the value and significance of such data. They should be had from all typical locations in the United States.

It should be of practical value to the farmer to know that in Kentucky tobacco takes about five times as many labour units as corn, and about twice as many power units; and that the wheat-crop requires about one-fifth as much work as corn. 
When considering the problem of substituting one crop for another, the farmer may have a basis for comparing the amount of labour required by each crop.

Relation of Crops to IMarkets.-An important fact to take into consideration relative to cropenterprises is the reliability and stability of their market-value. The farmer does not want to spend his time on products that he cannot market at a fair price. A presentation of the factors which in any particular locality makes the market-value of a crop reliable would lead to a discussion of railroad facilities, warehouses, elevators, cold-storage plants, marketing, organisation, crop advertising, etc. These are problems of rural economics. The farmer, however, should know and appreciate the importance of these factors when selecting a new cropenterprise. Many localities that have natural advantages for certain crops do not have these economic advantages, or rather other enterprises may have greater advantages, thus eliminating such an enterprise by competition. The trucking and fruit industries are restricted to certain quite definite localities, because at the present time these have superior economic ad- 


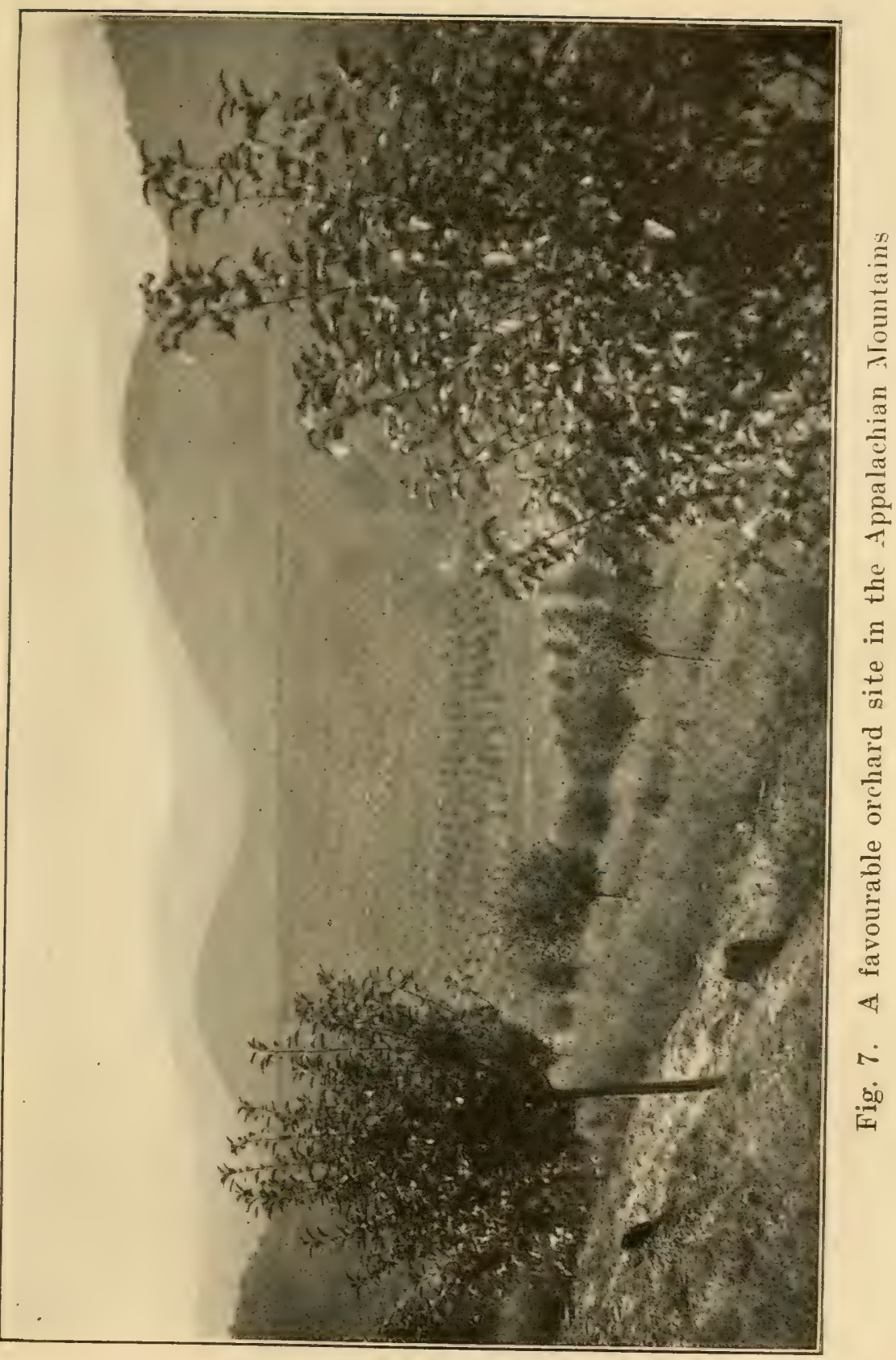



vantages. Northern Iowa and southern Minnesota could grow large yields per acre of Duchess or Wealthy apples of the finest quality, but in that region other crops are handled to much better advantage. Tomatoes, strawberries, and peaches are grown profitably in particular localities, not because of any particular natural advantages, but because in these places facilities have been developed for handling and marketing such crops. The raising of sugar-beets is profitable only where facilities for handling the crop have been established. In almost all cases, the owners of sugar-beet factories finance the crop, furnishing the seed and contracting for the crop from the farmer at a stipulated price.

A staple crop is one which has a long and well established market. The facilities for handling such crops and distributing them after they reach a shipping-point are most thoroughly organised and established in the commercial system of the world. The crops that fall into this class are those which may be held in storage without loss in quality, and which may be shipped to any part of the world conveniently. Cotton, corn, wheat, oats, tobacco, are well- 
known staples. In marketing these crops there has as yet been developed but little formal organisation in the United States. It must be remembered, however, that the crops that are staple in the world of commerce are not necessarily grown and handled with profit anywhere soil and climate may be favourable. The importance of the factor of transportation has already been shown. Even though the facilities for handling the crop may be easily provided on the farm, other fundamental economic factors may over-balance them. Railroad transportation-rates, for instance, are adjusted largely on the basis of established industries. This tends to increase the localisation of certain crops. Unless crops are grown in a locality in sufficient amount, there would be no inducement to expend capital in building shipping-facilities at railroad shipping-points near such localities. The most that could be expected in the way of providing advantages would be that cars would be provided for shipping in carload-lots. In doing this the farmer would need to consign his produce to a commission-house in a market-centre, or go with the car and attempt to sell it in- 


\section{FARM CROP PROBLEMS}

dependently. These duties require skill acquired by experience, and the average farmer would not be justified in attempting to acquire it in this way. The plain fact is that to dispose profitably of the most staple of crops requires well-organised local trading-facilities, such as warehouses, elevators or other storage-plants, banks and standard shipping-rates. Nor can many crops be efficiently marketed until such crops have acquired a reputation which is identified with the locality.

These facts explain why it is that in years of abnormally large production of any crop some localities will maintain a fair price for the product, while in others the price falls much below the cost of production. Throughout the South, northern potatoes have for many years enjoyed a reputation for good quality as compared with the average locally grown potato; yet many of the higher lands in the South may produce equally good potatoes. It may not be profitable, however, for one or even a few farmers to grow large quantities of this crop, even in the most naturally favourable localities, until consumers are convinced that the quality is to be re- 
lied upon. Such crops as corn, wheat, hay, cotton, tobacco, and potatoes, have maintained for many years a fairly stable and reliable price. With rare exceptions when a farmer has been able to grow and put on the market conveniently any of these crops, he was practically sure of getting paid for the capital invested and for his labour. One advantage of these crops to the farmer is that they may be held for a year, at least, without serious loss. If the quality is good, he is practically sure of a fair price any time of the year.

In farming, any permanent net increase in excess of average wages will tend as a rule, to become capitalised, and thus included in rent; that is, if a farmer finds that his soil and situation have special advantages, if special trade facilities have been developed, or if the place has a good reputation, he naturally and rightly considers these as elements in farm-value, and should thus expect to earn additional rent to represent the cost of these advantages. Taking into account this tendency to capitalise profits, and the fact that many are enabled to keep on farming at a loss owing to the family living pro- 
cured from the farm, ${ }^{1}$ it will be found that the average price over a series of years of nearly all crops will about coincide with the cost of production. If production increases to such an extent as to lower the price below the cost of production, the acreage will decrease until the production is brought down to a point where this relation will become more nearly normal.

It is to the advantage of the farmer as well as to the trader to understand these fundamental economic principles.

For instance the yield of corn coincides with the rainfall during the critical period of its growth. Hence the weather at that time affects its price. When the price is low on account of an abnormally high production fewer acres of the crop are planted the succeeding year. In the case of most staple crops grown in the United States the weather is indirectly fundamental in regulating prices. The reports of crop production published by the U. S. government and by the States show the influence of prices on production of the staple crops. Everybody who watches the markets of staple

1 See U. S. Dept. Agr. Farmers' Bulletin 635-What the Farm Contributes Directly to the Farmer's Living. 
crops reported in the daily papers must notice how potently weather-conditions react on the mind of the speculators who set the prices of these products for some months in the future.

On each crop the prices vary to some extent during the year. If one takes the average of these variations for a series of years there will appear what may be termed a normal variation. These variations are easily interpreted by those who are thoroughly familiar with conditions that effect prices. In the case of wheat the price rules the highest before the new harvest. Wheat put on the market at that time has been subjected to considerable shrinkage, and mills which want wheat to grind for flour can afford to pay higher prices for the old wheat. Other factors no doubt combine also to affect the price at this time. 


\section{CHAPTER VI}

\section{PROBLEMS OF LIVESTOCK}

ON most farms livestock enterprises are as important as crops.

Where markets for field-crops are not easily accessible, but where pasture grasses and forage-crops do well, stock may be virtually the only direct source of income. In many parts of the corn-belt nearly all the corn-crop is fed to cattle. In such cases it may be said that livestock furnishes the most practical and profitable means of marketing crops. The fact that the transportation of animals is a relatively unimportant item in their cost makes it possible to breed and grow young animals in one place and distribute them to others for further development. Thus cattle are reared on cheap grazing land until two or three years old, when they are transported to another place and grazed a short time, after which they are fed on grain and marketed as beef-cattle. 
For many years in parts of Virginia, West Virginia and North Carolina, cattle have been grazed on bluegrass mountain-pastures and wintered on farms in the valleys nearby. Formerly they were often driven long distances to where hay could be produced cheaply. The hay was put up in small round stacks, from which in the winter it was hauled and scattered over the meadows for the stock to eat. In the spring the cattle were driven back to the bluegrass pastures, and in the fall sold to feeders or as fat cattle on the market. In this manner of feeding, the hay meadows were formerly kept in a highly productive state for many years.

This migration of livestock in response to the physical and economic situation in the locality is an important and significant fact in farming. Stock-cattle raised on mountain pastures, and on the cheaper lands in the West, still furnish most of the cattle which are fed in the corn-belt, and sold in the great stock-markets. Young mules are found on the bluegrass farms of Kentucky, Tennessee, and Missouri. When old enough, they are distributed to all parts of the country for work on farms, in mines, and so on. 
In the case of such animals as hogs and sheep, the season of development for market is short. Lambs are sold profitably at four to six months of age. Hogs mature for the market in six to twelve months. For this reason these animals less commonly migrate in the process of development for the market.

Migration of Cattle.-To illustrate how stockcattle may move about the country until their final marketing the events on a grazing farm on top of the Allegheny Mountains may be described. This farm includes 5,000 acres, divided into 500-acre fields, each field carrying about 100 thousand-pound animals from May till October, and a few horses and sheep in the winter. One year several car-loads of steers were shipped in the fall from Amarillo, Texas. These steers probably weighed about 700 pounds each, and at that time sold in Texas for about $\$ 30$ per head. The transportation and board to the West Virginia grazing farm made the cost there about $\$ 36$. After a few weeks grazing they were driven to valley farms where, during the winter, they lived mostly on corn-stover, straw, and possibly a little hay and corn during 
the late winter months. The charge for this feeding was about $\$ 1.50$ per month a head for about five months, making about $\$ 7.25$ for the winter's board. About May 1 they went back to the bluegrass pastures where they grazed until about October 1. This grazing land had a market value of about $\$ 50$ per acre, so that it should yield the owner a rent of at least $\$ 2.50$ per acre a year. About four acres of this land would carry one animal a year, so that the rentcharge for grazing one of these steers was about $\$ 10$. Two men handled the cattle on this large grazing farm, and the estimated cost of labour, salt, depreciation, etc., was about $\$ 4$ per head. These cattle thus left this farm for the feedingpens in central Ohio, or for the Pittsburgh or Baltimore market, having cost about $\$ 57.25$, and weighing 1000 to 1100 pounds. Under present conditions similar cattle handled in this manner would leave the farm costing about $\$ 70$ per head.

Decline of the Industry.-In the United States most of the stock-cattle have been reared on the great plains. As farms have developed in that region, the grazing areas have been pushed farther west, on less productive land, and into 
Mexico, where stock-raising is hazardous on account of political conditions. Because of this limitation of the grazing area, the number of cattle has declined in the United States, so that in 1914 the number was about the same as in 1892.

This condition has given rise to a great deal of concern. Farmers are being urged to raise more young stock on the farms. In the Southern States, where the livestock industry has not prospered, mainly on account of climatic conditions, efforts are being made to stimulate its development.

Livestock production may be increased in several ways. A situation making its products high and feed relatively cheap would increase production. The cheap growing of pasturegrasses and forage-plants on lands now waste, or the discovery of better means of utilising certain farm-crops that now have only a limited market, would stimulate production. One thing is absolutely certain, and that is that the farmer will not increase the livestock on his farm unless he is convinced there is more profit in it than in raising and marketing crops. 
From the farm-management point of view the feeding of livestock on a farm is an important factor as a means of increasing or maintaining soil-fertility. Farms, however, may easily be overstocked, so that the quality of the stock raised or fed suffers. Often pastures on farms are eaten down too closely, and everything in the nature of forage is so cleaned up that little remains to go back into the soil as vegetable matter-an ingredient as necessary for the productiveness of most soils as are the mineral ingredients. The marked increase in the productiveness of soils in many parts of the corn-belt is beyond doubt due to the feeding of beef-cattle, an industry which has been profitable there for many years.

As a Source of Income.-It has been noted in former chapters that livestock enterprises do not appear to be as important as a source of income in some places as in others. In the more southern localities, for instance, the greater part of the income is derived from field-crops, while in the more northern localities, and in the higher altitudes of the south, stock-enterprises are the sources of greatest income. This differ- 
ence is undoubtedly due largely to contrasts in climate. In most northern climates the winters are long and cold, when practically no fieldwork may be done, and livestock gives work. Cold weather in the winter, and the cool springs and autumns with a relatively short hot season, make conditions favourable for the production of dairy products. Feeders, especially, thrive well with cheap temporary shelter in the dry, cold winters of the North-central States. Here the relatively high rainfall during the hot summer months is in contrast to the relatively dry summers in the south, and, combined with a remarkably fertile soil, conditions are favourable for the production of most kinds of animals.

In the Appalachian Mountains the higher levels, as has been noted, receive frequent rains, and the amount is large as compared with other sections. Where the soils in this region are derived from limestone, or where soils contain lime, such as do most of the red soils of West Virginia, bluegrass grows vigorously, maintaining itself against weeds and tree-sprouts. Such districts are largely developed for grazing. The bluegrass regions of Kentucky and 
Tennessee are famous for the production of saddle horses, mules, and export beef-cattle. The advantages for livestock production in these sections lie mostly in the soil, which contains a large amount of lime-phosphate, an ingredient especially favourable for the vigorous growth of bluegrass, and the heavy clay subsoils hold moisture well. The climate, however, is not so favourable, as may be seen from charts showing the type of climate. The long, hot summers are relatively dry. Then, too, much of the soil lies shallow on the limestone rock, which is impervious to moisture except through cracks and crevices. Wells are not a reliable source of water, and most of the water for stock is surface-water held in ponds made at convenient places on the farms.

Indirect Benefit.-In the economy of farm-organisation stock-enterprises may be considered mainly from the point of view of the most profitable utilisation of grain, hay, and forage crops and of such by-products as would be largely wasted unless fed to stock. On a large number of farms straw, corn-fodder, by-products of the dairy, etc., are utilised to advantage by the right 


\section{PROBLEMS OF LIVESTOCK 131}

kind of animals. Where winter grains are raised, and such winter cover-crops as vetch, crimson clover, and rape, stock of various kinds may graze profitably during the fall, winter and spring months, and fall and winter lambs may be profitably reared and marketed. In some cases livestock may serve a useful purpose in subduing the enemies of crops. For instance, sheep have proven to be valuable animals in keeping down weeds in orchard grass. So valuable were these animals found to be for this purpose in a well-known orchard-grass section, that farmers having no sheep borrowed their neighbours' sheep for this purpose. The use of goats for destroying young tree-sprouts is wellknown.

Farmers in the corn-belt, and those who live on high-priced land, have not, as a rule, found it profitable to raise young stock. Except where cattle are "finished off" on permanent pasture on such farms, they are kept but a short timetwo to four months. They are expected to utilise the grain and other food profitably, and are kept only as long as is necessary to accomplish this purpose. 
Animal Units.-In discussing the use of animals on the farm it has been found to be convenient to reduce each class of animals to terms of a common unit. The average cow, steer, horse, or mule may be considered an animal unit, since the average animal of any of these classes will eat about the same amount of feed.

\section{TABLE 4}

SHOWING EQUIVALENT OF DIFFERENT CLASSES OF LIVESTOCK IN TERMS OF ANIMAL UNITS

1 steer, cow, horse or mule........... 1 animal unit

2 calves, heifers or colts

7 sheep

14 lambs

5 hogs

10 pigs

100 chickens

The number of animal units that may profitably be kept on a farm will depend on the situation and size of the farm, the soil and climatic conditions, the type of farming, the croppingsystem, and on varying market conditions. This will be discussed hereafter.

The growing-season and available time for field-crop work has an important relation to the livestock problems. In a region where these are 


\section{PROBLEMS OF LIVESTOCK}

long, where the soil is not well adapted to pasture-grasses, a man may find that he can make more profitable use of his time and capital by spending a relatively large portion of it on cropproduction and only a small portion on livestock. Livestock enterprises and field-crops then may be combined to distribute labour to advantage. In the corn-belt, where cattle feeding is extensively carried on, the farmer gives his attention to feeding animals from about October to May, when little field-work may be done. During the growing-season most of the livestock is off his hands, so that there is little interference with work.

The raising of lambs for the early spring market, or even for a late market, is an excellent enterprise in relation to the distribution of labour; and hogs in certain types of farming may easily be made inportant in this relation.

Labour Expense of Keeping Livestock, - Livestock enterprises are noticeably different from crop enterprises in that the latter require a much larger labour expense in proportion to value. 
than do the former. While the labour-expense of livestock enterprises is relatively low, the expense for food, materials and equipment is high. The labour is largely routine or daily labour, which is affected little by the weather, and dairy cattle and poultry must receive about the same amount of attention the year round, and therefore such enterprises are often profitably carried on alone. Nevertheless at certain definite periods special work is called for. For instance sheep need to be sheared at the proper time and lambs must be cared for during the lambing season. On the average farm, the routine work is largely included in "chores," which the farmer and his help do in the morning and evening, so that but little of the time available for field-work is devoted to caring for stock. On some larger farms, however, the stock may require the continuous time of one or more men. On a 1000 -acre farm in Tennessee, employing ten to fifteen labourers, one man manages the crop-enterprises, another the livestock; and a daily record of time spent shows that for 200 animal units the entire time of two men was employed. 


\section{TABLE 5}

SHUWING LABOUR AND POWER UNITS PER ANIMAI. UNIT ON SEVERAL GRAZING FARMS

\begin{tabular}{l|c|c}
\hline \multicolumn{1}{c|}{ Class } & $\begin{array}{c}\text { Labour units } \\
\text { per year }\end{array}$ & $\begin{array}{c}\text { Power units } \\
\text { per year }\end{array}$ \\
\hline Steers $\ldots \ldots \ldots \ldots \ldots \ldots$ & 1.00 & 1.00 \\
Hogs $\ldots \ldots \ldots \ldots \ldots \ldots$ & 1.50 & 0.75 \\
Calves and lambs $\ldots \ldots$ & 1.45 & 0.20 \\
Dairy cows $\ldots \ldots \ldots \ldots$ & 14.00 & $\ldots$ \\
\hline
\end{tabular}

From survey-records on about 50 farms in a well-developed farming district in West Virginia, on the average farm, with about 32 animal units, about four hours per day were required to feed and care for the animals, including work-stock.

The proper feeding and handling of livestock on the modern farm has come to be a specialised and somewhat technical business. Take the feeding of steers for the market, for instance. To be the most profitable, it requires experience and especially good judgment in buying. The shape of the animal, and certain features of the hair, skin, etc., will indicate to the expert cattlefeeder first-class qualities. Standard rations for all classes of livestock have been worked out and are available to any one wishing to know 
about them. The successful feeder, however, must know how to vary such rations to suit the appetite of the animals. In such undertakings the knowledge most essential for success is that which can be secured only by experience, accompanied by keenness of observation and ability to grasp principles.

Livestock and Soil-fertility.-Livestock is generally considered of great value in keeping up the fertility of the soil. In a previous chapter cattle-feeding was briefly discussed as a means of securing soil-fertility. In this country, as a rule, farmers have not placed a high value on manure. In an agricultural survey made in West Virginia, about forty years ago, it was observed that usually manure was thrown out of the barn into a ravine or creek to be washed into the river. This practice is too common in that State today, as well as in other places. Of course the hauling and spreading of manure costs money, and the farmer must realise that it pays to put it on the land before he goes to the expense of hauling it. The following table from Warren's "Farm Management" gives the scientific facts relative to manure, as worked 


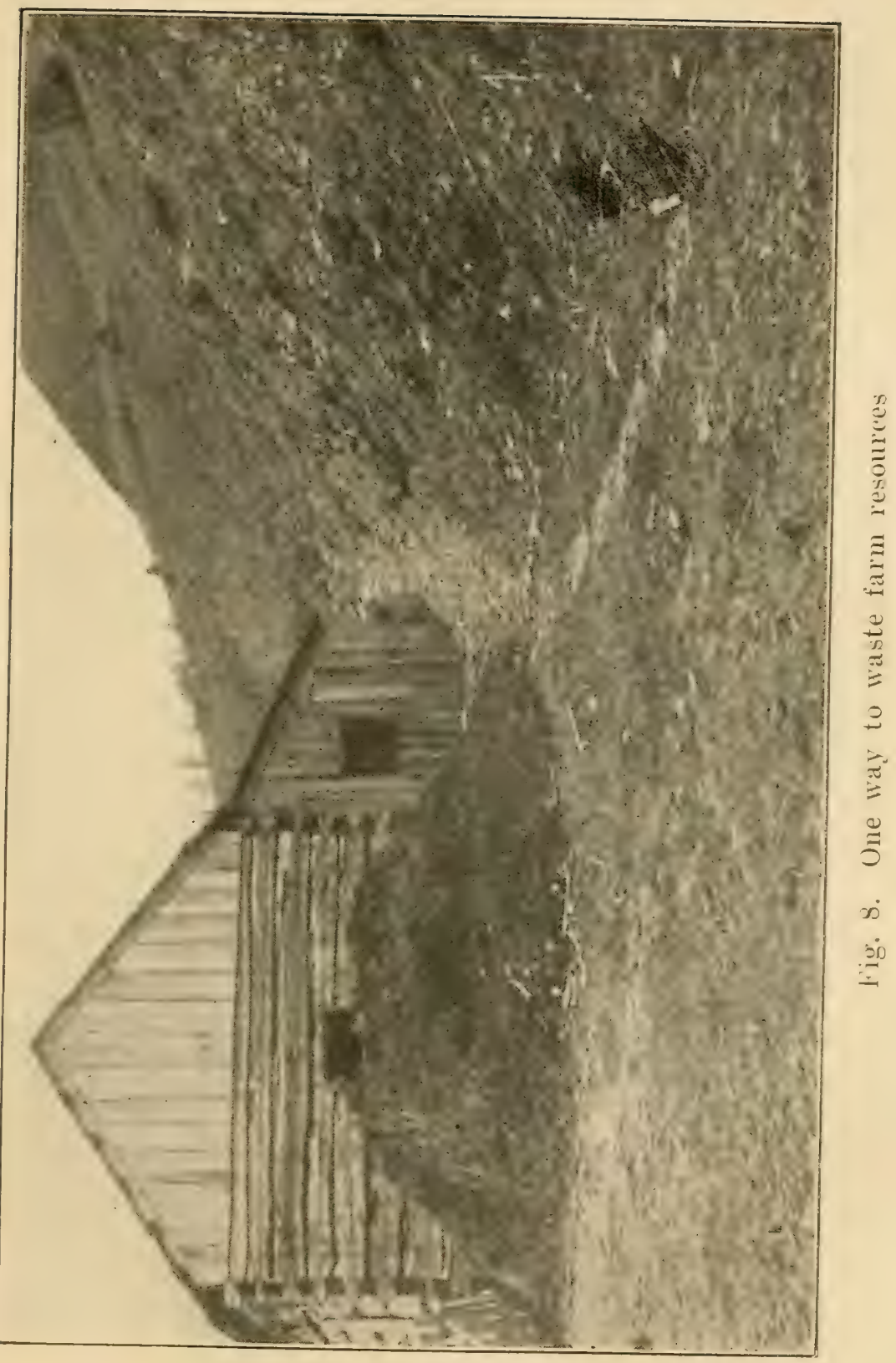



out by Roberts, and is a good basis upon which to calculate its value on a farm; the cost of the fertilising ingredients, nitrogen, phosphorus and potash vary in different localities.

TABLE 6

MANURF PRODUCED PER 1,000 POUNDS OF LIVE IVEIGHT PER YEAR

\begin{tabular}{l|r|r|r|r|r|r}
\hline & $\begin{array}{c}\text { Excre- } \\
\text { ment } \\
\text { tons }\end{array}$ & $\begin{array}{c}\text { Manure } \\
\text { with } \\
\text { bedding } \\
\text { tons }\end{array}$ & $\begin{array}{c}\text { Nitro- } \\
\text { gen } \\
\text { pounds }\end{array}$ & $\begin{array}{c}\text { Phos- } \\
\text { phorus } \\
\text { pounds }\end{array}$ & $\begin{array}{l}\text { Potash } \\
\text { pounds }\end{array}$ & $\begin{array}{c}\text { A prox- } \\
\text { imate } \\
\text { cost } \\
\text { if pur- } \\
\text { chased } \\
\text { in fer- } \\
\text { tilisers }\end{array}$ \\
\hline Horse ... & 8.9 & 12.1 & 15.3 & 81 & 150 & $\$ 33.72$ \\
Cow .... & 13.5 & 14.6 & 137 & 92 & 140 & 31.20 \\
Sheep ... & 6.2 & 9.6 & 175 & 88 & 133 & 36.84 \\
Calf ... & 12.4 & 14.8 & 150 & 105 & 102 & 32.28 \\
Pig .... & 15.3 & 18.2 & 331 & 158 & 130 & 64.48 \\
Fowls ... & 4.3 & $\ldots .$. & 293 & 119 & 72 & 54.52 \\
\hline
\end{tabular}

On most farms manure is considered worth about $\$ 1$ per ton at the barn, but on some truckfarms near cities it is worth $\$ 2$ per ton.

It has been estimated that about two-thirds of the fertiliser ingredients found in the feed of animals is recovered in manure. According to investigations, only one-third to two-thirds of the manure produced on farms is actually put on the land. Of course a good deal of it that is not accounted for by the farmer gets on to the land 
by animals grazing, or walking about over the land, and in some places the greatest value of the manure is found to be in the humus it supplies to the soil. In such cases farmers find that straw and other forms of by-products give practically the same results as manure.

From the table it may be seen that the value of manure per 1000 pounds of weight from hogs and poultry is about twice as great as that from other classes of livestock. The reason for this lies in the fact that hogs and poultry eat about twice as much per pound of weight as do other domestic anirnals. It may be safely assumed that a farm carrying about 35 livestock units (livestock reduced to 1000-pound units) will theoretically produce about 450 tons of stablemanure. Under average conditions one-half to two-thirds of this amount will be made use of on the farm. On the best farms, where much of it is hauled directly from the stable to the field, and where the remainder is well taken care of in specially provided places, probably nine-tenths of the value may be saved. If 350 tons out of the 450 produced could be scattered on the land at the rate of 10 tons per acre, about 35 acres of 
a farm should be covered each year. On the average farm of 160 acres, with a four- or fiveyear rotation, the fertility of the best lands ought to be fairly well maintained by this means. The mineral fertiliser alone contained in this amount of manure would cost on the market nearly $\$ 1000$. The spreading of these mineral elements on the land in the form of manure involves, of course, a large item in labour, but this should not cost the farm over $\$ 150$, allowing for waste, cost of hauling, etc.

If it be assumed that the crop-products fed to animals would otherwise be taken from the farm, the value of each animal unit to the farm, as a means of conserving fertility, ought not to be less than $\$ 20$.

Utilisation of Waste.-On many farms such byproducts as straw and corn-stover commands little if any market value. In order to command market value the price obtained should exceed the cost of producing and hauling them to market. The usual farm-price for corn-fodder in shock, where there is a ready market, is about $\$ 2$ to $\$ 4$ per ton (the product of about an acre of 50-bushel corn). Straw unbaled in the same 
localities will have a farm-value of $\$ 1$ to $\$ 2$ per ton. Taking corn as the standard for stock-food value, these products are equivalent to about .25. In such cases, of course, it is assumed that all the material is eaten. Practically, however, these rough feeds are seldom more than half consumed. Thus a corn-crop of 40 bushels per acre will produce about 1500 pounds of stover per acre. Theoretically this would have the food-value of about seven bushels of corn, and practically about three to four bushels; at 75 cents per bushel this would be worth $\$ 2.25$ to $\$ 3$ per acre, a considerable item in the income from the land. Ordinary wheat-straw, while producing about the same weight per acre for a 20 bushel crop, has practically less feeding value than corn-stover. Still its utilisation for feed on the farm may be of considerable consequence. As a matter of fact it is a general practice in good agriculture to feed young stock such roughage during the winter, counting on summer pasture to put on growth and fat. In the bluegrass region of Kentucky steers are bought at two to three years old in the fall, "roughed through" the winter, and sold off the bluegrass 


\section{PROBLEMS OF LIVESTOCK 141}

pastures in the fall. In this manner the fine "export cattle" were produced for many years; and by such a practice a value is created for the by-products of the farm. This practice also increases the manurial value of the material utilised by stock, since in this way it is put into a better mechanical condition, to serve as manure. In fact, such products are seldom returned to the soil in any other way, as when not fed they have too frequently been burned or otherwise wasted.

Because so much of the livestock raised on farms utilises products that would otherwise be wasted, and because in many cases it may be handled to fill up gaps in the work-periods of the farmer, it is difficult to estimate the actual cost of raising it. Thus in many good agricultural districts, while the raising of young stock would not pay as a major farm-enterprise, a few animals might increase the total profits on the farm. Most of the poultry and poultry-products marketed in the United States is produced on ordinary farms at a really low cost because 75-120 chickens on the average farm live largely on products that otherwise would be 
wasted. The care of such a number is regarded as a sort of side interest by the farmers themselves, or as a relief from routine work in the house by the wife.

From a business record on a West Virginia farm, considered by the owner and his neighbours as a dairy farm, the following statement showed the sources of his income:

Crops .............. \$424 Butter and milk (6 cows) 210 Poultry ............ 25
Stock $\ldots \ldots \ldots \ldots \$ 300$

Eggs (125 hens).... 375

In this case, poultry treated as a minor enterprise is on the basis of farm income the major enterprise. The poultry on this farm, however, were of extra quality and were well cared for.

In handling livestock-enterprises the object in most cases is to make profits on natural increase and growth of animals, on animal products, such as dairy-products, eggs, wool, etc., or in fattening animals on special rations. Such animals as horses and mules, on the other hand, increase in value also by training. Until recently the breeding and training of saddlehorses and trotters was one of the important enterprises in the bluegrass section of Ken- 


\section{PROBLEMS OF LIVESTOCK}

tucky. The system of training was complicated, requiring at various stages of development the attention of experts. The horses thus trained had to have a high market value in order to pay for the labour expended on them. The breeding and raising of thoroughbred stock is an enterprise engaged in by a few who have given the subject a special study, and who are able to finance the advertising features of the business.

Profits from Cattle.-When cattle are being fattened the farmer expects the largest possible increase in weight at the minimum cost of feed and labour. The dairyman measures his success by the quantity of milk or butter-fat produced for a given cost of feed and labour. The most important factor in getting results along. this line is quality in stock, as is well illustrated by a dairy herd of Guernsey cows. Eight head of thoroughbred cows averaged 10,689 pounds of milk and 501 pounds of butter-fat. Eight grade cows fed in the same barn with the same care averaged 5952.9 pounds of milk. The best thoroughbred produced 13,570 pounds of milk and the best grade 8784 . The board of these cows and the labour of milking cost $\$ 20$ per 
month each. In this case about 70 cows lived luxuriously in a $\$ 10,000$ barn; moreover, the thoroughbreds were valued at not less than $\$ 1,000$ each, so that, counting interest on investment, depreciation, insurance and items of service, the thoroughbreds, even though milk brought 8 cents per quart, would not much more than pay for themselves, since the total cost of such cows would be about $\$ 400$ per year, while the milk produced brought only $\$ 427$, leaving a profit of about $\$ 27$. The grade cows in this herd did still worse financially, since at a cost of about $\$ 265$ they produced only about $\$ 238$ worth of milk at 8 cents a quart. But the owner, as a breeder of thoroughbred animals, could make money by having the cows of poor quality teach a valuable lesson.

A good average dairy cow should be expected to produce at least 5000 pounds of milk and about 250 pounds of butter-fat per year, on about 1500 pounds of grain and concentrates, and 1900 pounds of hay and roughage- 7500 pounds of silage and about 180 days on pasture. On the average dairy farm the entire labour-requirement per cow is about 30 minutes per day. This 
includes marketing the milk, making the butter, etc. ${ }^{1}$ Under less luxurious surroundings, such as an ordinary clean farm could furnish, the total expense in the same locality should not exceed $\$ 150$.

Steers of good quality should gain about $21 / 2$ pounds per day during the feeding period. The average shote or hog, on a fattening ration, should gain about $11 / 2$ pounds per day; or about 9 to 12 bushels of grain should make 100 pounds gain. Hens properly cared for should lay about 120 eggs per year. On the average farm hens lay about 60 eggs each. Sows are expected to raise, until weaning time, at least ten pigs per year in two litters. Ewes are expected to rear at least 100 per cent. of their number.

Depreciation.-In counting the cost of raising livestock one of the most important items is depreciation. Animals are liable to many diseases that it costs money to control, and, even with the modern knowledge and equipment for

1 The cost of keeping a dairy cow varies greatly according to methods of feeding and keeping the cow, and with location. The regular dairymen find the total cost to vary between $\$ 80$ and $\$ 150$ including all costs. The ordinary farm cow costs much less $-\$ 50$ to $\$ 75$ per year. 
control of diseases, the loss is often disastrous. The better breeds of livestock are more liable than the poorer to succumb to diseases and the hardships of ordinary farm life, so that the depreciation is greater with this class. It probably would not be far out of the way on the average farm to allow 10 per cent. for cost of depreciation. The variation is very great for different classes of livestock. Even with dairy cows the variation is great on account of value of animals, breed, etc. Depreciation on sheep, hogs and hens is probably higher than on any other class of animals, on account of special liability to diseases, and enemies of various kinds.

In selecting and handling crops on the farm it was pointed out that good management was indicated in keeping a proper relation between total expenses and production, and to aim for high prices for products. This point of view is specially important in dealing with livestock. In order to get high prices for the produce the quality must be good. The following table gives the prices of the same class of livestock, but different in grade, for the same period, illus- 
trating how it is possible for a farmer to buy feeders at the proper time of year, feed them his grain, and sell them almost any time of the year for at least a dollar per hundredweight higher than the price paid. Cattle-feeders usually consider the business a losing one unless they are able to realise this difference in price.

The profitableness of any class of livestock on a farm depends also on market facilities, just as was pointed out in the previous chapter on crops. There are forces which tend to localise the enterprises. Thus butter and cheese making are confined to three or four States in the North where relatively cheap feed is accessible, where markets are established, where there are facilities for handling, and where there is an established reputation for reliable products.

TABLE 7

SHOWING AVERAGE PRICE FOR FOUR YEARS OF TWO CLASSES OF STEERS IN THE MARKET

\begin{tabular}{|c|c|c|c|}
\hline $\begin{array}{l}\text { '99-'0s } \\
\text { Month }\end{array}$ & $\begin{array}{c}\text { Price per } 100 \text { ut. } \\
\text { Best fat steer } \\
\text { Cincinnati price }\end{array}$ & $\begin{array}{l}9.9-0.9 \\
\text { IIonth }\end{array}$ & $\begin{array}{l}\text { Price per } 100 \text { ut. } \\
\text { Common steer } \\
\text { St. Louis price }\end{array}$ \\
\hline $\begin{array}{l}\text { Tan. .... } \\
\text { Feb. .... } \\
\text { Mar. .... } \\
\text { Apr. . . . } \\
\text { May . . . }\end{array}$ & $\begin{array}{r}\$ 5.45 \\
5.34 \\
5.30 \\
5.49 \\
5.48\end{array}$ & $\begin{array}{ll}\text { Jan. } & \ldots \\
\text { Feb. } & \ldots \\
\text { Mar. } & \ldots \\
\text { Apr. } & \ldots \\
\text { May } & \ldots \\
\end{array}$ & $\begin{array}{r}\$ 3.82 \\
3.81 \\
3.98 \\
4.17 \\
4.21\end{array}$ \\
\hline
\end{tabular}




\section{FARM MANAGEMENT}

\begin{tabular}{|c|c|c|c|}
\hline $\begin{array}{l}\text { '99-'03 } \\
\text { Month }\end{array}$ & $\begin{array}{c}\text { Price per } 100 \text { wt. } \\
\text { Best fat steer } \\
\text { Cincinnati price }\end{array}$ & $\begin{array}{l}\text { '99-'03 } \\
\text { Month }\end{array}$ & $\begin{array}{l}\text { Price per } 100 \text { wt. } \\
\text { Common steer } \\
\text { St. Louis price }\end{array}$ \\
\hline June & 5.62 & June & 4.00 \\
\hline July ... & 5.70 & July. & 3.87 \\
\hline Aug. ..... & 5.84 & Aug. ..... & 3.88 \\
\hline Sept. . . . . & 5.73 & Sept. ..... & 3.99 \\
\hline Oct. .... & 5.64 & Oct. $\ldots \ldots$ & 3.54 \\
\hline Nov. ..... & 5.50 & Nov. ..... & 3.48 \\
\hline Dec. ..... & 5.67 & Dec. ..... & 3.63 \\
\hline
\end{tabular}




\section{CHAPTER VII}

\section{FARM ORGANISATION}

IN previous chapters the various resources and factors which must be dealt with in managing a farm have been discussed briefly. Crops and live-stock enterprises are the means through which the resources of the soil and climate are made available for use and profit.

The farm may have important advantages due to location; otherwise such advantages must be had through control. Natural advantages, such as good soil, favourable climate, and nearness to market, become capitalised, and in a well-developed agricultural district have to be bought at prices commensurable with such advantages; and, as has been shown, to secure advantages by means of control also costs money. A new and undeveloped section may have natural advantages, but to secure these often requires patient waiting, experimenting, and the endurance of considerable hardship.

The farm is a human institution, which means 
that agricultural practices and systems of farming developed in the past are handed down from generation to generation. These practices and systems, of course, improve and change in response to a new environment or changes in economic conditions. It is characteristic of human institutions that when once established they normally change only gradually and conservatively, but ultimately the most fit must prevail. This is characteristic of the farm-institution, as it develops in response to the agricultural needs of the people.

What Constitutes Organisation.-The selection and adjustment of crops and stock-enterprises to the natural and economic environment, the proportion of these to size of area, the relation of available capital and labour to the size of business, together constitute farm organisation.

Given a definite situation, the resources to a certain extent may be measured. The soil has a certain degree of productiveness and is adapted to certain crops. The climate limits the rainfall and its distribution; also the growing-season and the number of days available for field-work. Accessibility to market and the 
general economic situation limit possibilities. The types of farms that have developed and survived surrounded by a set of such conditions have a rational explanation, because the price of land, the area farmed, the rotation system followed, the amount of each kind of crop, the number of each kind of live-stock, bear some relation to the farm as a unit. When we attempt to analyse a farm from this standpoint we study farm organisation.

In any line of human endeavour organisation results when there is an attempt to economise the resources dealt with. When the farmer can devise a crew of one man and six horses to do his ploughing, he is saving the labour of one to two men, and is applying the principles of economy on his farm. When the crops growing on a farm are not only such as are adapted to soil and climate, and to marketing opportunities, but also secure good distribution of labour and co-operate to maintain the fertility of the soil, there is evidence of relation between such crops and the farm as a whole. Such a farm is well organised. The rotation of crops, the arrangement and size of fields, the location and general 
planning of buildings and yards, are also problems of farm organisation.

In Chapter $\mathrm{V}$ a chart is given showing how a single crop, even well adapted to the region, cannot profitably occupy men and teams engaged in farming. By combining two crops, as corn and oats, a better and more profitable distribution of labour occurs. By raising oats with corn there is opportunity to do fall ploughing, thus allowing the available time in the spring to be used not only in planting more corn, but almost as large an acreage of oats besides. But the problem of maintaining fertility is also a serious one, so that a crop valuable for this purpose has been selected to enter into the rotation. Red clover is the crop that has proved itself best fitted to supply the needs of fertility maintenance; and its labour-requirements, do not interfere to any extent with the corn-crop. During the several months in late fall and winter, when there are no days available for field-work, the feeding of corn to cattle and hogs is an enterprise that under prevailing economic conditions has proved to be a profitable means of marketing the corn. These en- 
terprises then, corn, oats, and clover, steers and hogs, enable the farmer in that region to employ his time profitably.

Labour as a Factor.-In many parts of the cornbelt the labour problem is serious, and partly as a consequence of this an interesting type of farm has developed. ${ }^{1}$ The enterprises are corn, rye, clover, timothy, and hogs. Labour is saved by having the hogs harvest the graincrops, and pasture on the clover and timothy. A 100-acre farm of this type may be operated by one man and a three-horse team, with the hiring of little extra labour. On such a type of farm the labour distribution is about as well provided for as could be desired. When the crops require attention the hogs largely take care of themselves. It is during farrowing time, and during the winter, that the hogs require the maximum amount of labour. The size of the fields and their arrangement are adapted to "hogging off." The planting of crops is timed in such a way that they are ready in succession to be harvested by the hogs. This type of farming and scheme of organisation may be adapta-

1 The organisation of this type of farm is described in U. S. Dept. Agr. Farmers' Bulletin No. 614. 
ble elsewhere. With different soil and climatic conditions different crops may be utilised.

In Fig. 9, there is shown the distribution and amount of labour required on a 100 -acre farm adapted to lower elevations, in the South-central States. The work on such a farm may be done by one man and three horses. The uneven line indicated by the letter $a$ marks off for each month the number of days which are available for field-work. The black columns indicate the number of days' work required of the man, and the column marked by diagonal lines indicate the number of days' work required of the team. This farm has 90 acres in cultivation, and the enterprises handled are corn, 36 acres, cowpeas, 18 acres, wheat, 36 acres. These relative acreages are only approximate. Farmers nowhere follow strictly, as a rule, the rotation they have in mind. The plan that got good results on this farm was to have five fields in the following crops:

\begin{tabular}{|c|c|c|c|c|}
\hline 1 & 2 & 3 & $\stackrel{4}{4}$ & 5 \\
\hline $\begin{array}{c}\text { Cowpeas } \\
\text { (catch-crop) }\end{array}$ & $\begin{array}{l}\text { Wheat } \\
\text { pastured and } \\
\text { turned under }\end{array}$ & $\begin{array}{l}\text { harvested } \\
\text { for seed }\end{array}$ & $\begin{array}{l}\text { (fallow } \\
\text { land after } \\
\text { harvest) }\end{array}$ & $\begin{array}{l}\text { Cowpeas } \\
\text { turned under } \\
\text { for corn }\end{array}$ \\
\hline
\end{tabular}




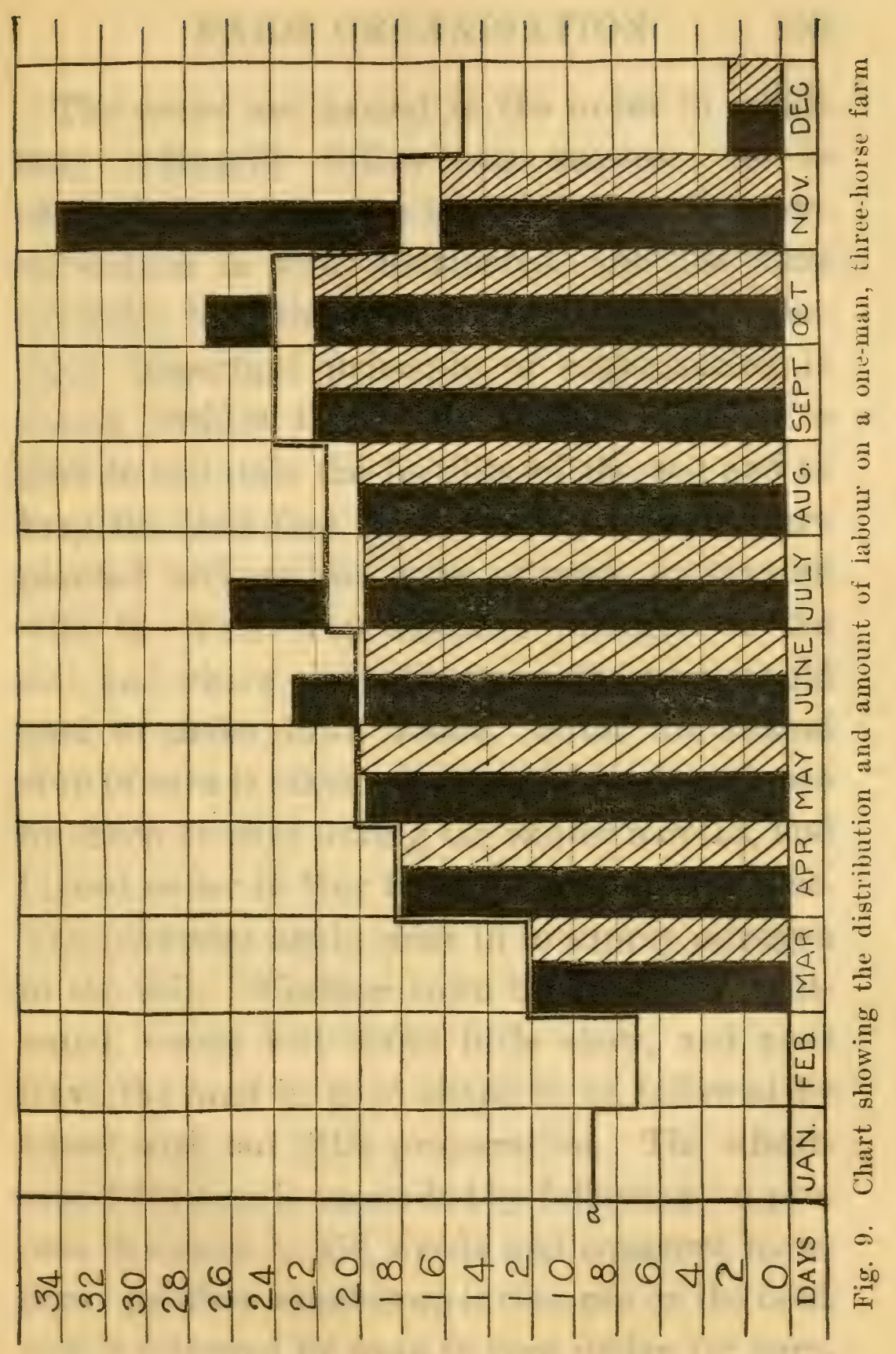




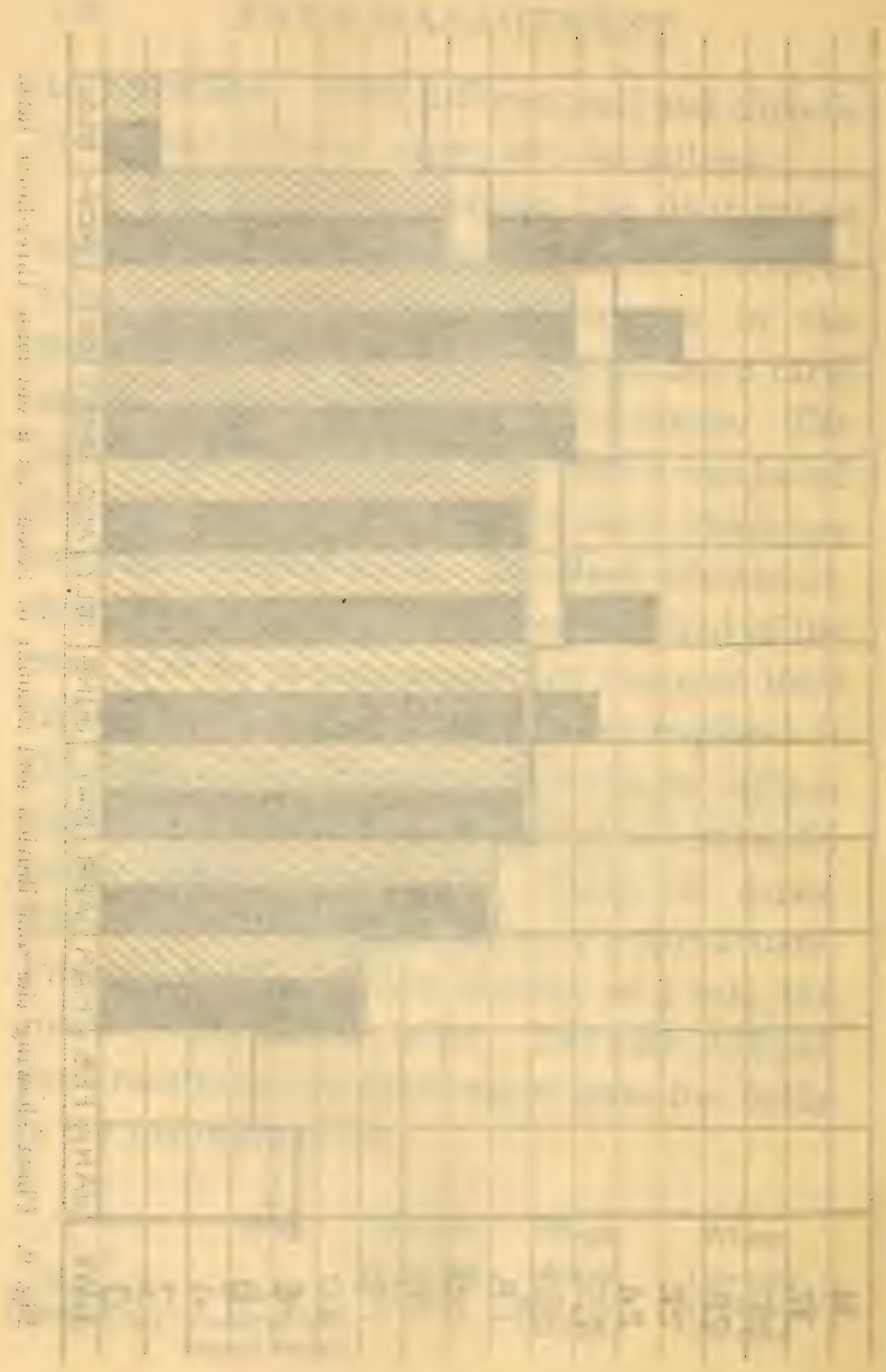


The crops are named in the order in which they ordinarily follow one another. As is shown in the figure, the labour during the growing-season is well distributed, and the time available for field-work is fully occupied. Another important principle of organisation is shown besides this. The system indicates a plan to maintain the fertility of the soil and to keep the land free from weeds. Cowpeas are planted between the rows of corn, or planted with it. This crop supplies nitrogen to the soil, and where planted between the rows would tend to choke down weeds. After the second crop of corn is taken off wheat is sown, pastured by sheep or hogs during the winter months, and turned under in May to be followed by cowpeas. Now, cowpeas again come in to supply nitrogen to the soil. Whether sown broadcast or cultivated, weeds will stand little show, and peas leave the land in good shape to be followed by wheat with but little preparation. The wheatcrop following is succeeded by fallowing-a process designed to kill weeds and conserve moisture. Another wheat-crop is then put on the field, and is followed by peas to turn under for corn. 
The corn on this farm is marketed through hogs. The year that a record was given on the farm the total production amounted to about $\$ 2000$, and the labour-income to about $\$ 540$. About 175 of the 200 days available were utilised in doing field-work. The days not used came in the late fall and winter, when virtually the only farm-work that may be done is ploughing, or hauling and spreading manure. Figured on the basis of the amount of time put in on fieldwork, such a farmer doing the work himself would earn about $\$ 3.25$ a day.

In the same latitude of the farm just described, and in the dark-tobacco belt of southwest Kentucky, a type of farm has developed which uses a larger acreage of land and is adapted to the labour-conditions of that region. The system of farming found established on this farm is indicated in the following outline:

Field 1

Corn-70A

Tobacco-20A
Field 2

Wheat-90A

(Follow corn and tobacco after disking ing.)
Field 3

Field 4

Wheat-90A

(Follows summer fallow of Field 2.)
Clover-90A

(First crop cut for hay and some of second crop for seedturned in fall and winter for corn.) 
This outline of a system of farming was the one in use on a particular 360-acre farm studied by the author and will serve as an illustration of the benefits of reorganisation. This farm uses ten mules as work stock and employs four regular hands eight months, and three regular hands four months, with such extra labour as is needed.

As operated under the system outlined above the distribution of both man and horse labour is poor. There is not enough work provided for regular available labour during the spring months, while during the summer months from June to September considerable extra labour is needed. This extra labour is required mainly on account of tobacco, which must have special attention during the growing period. (See Fig. 6.) Except in the rush season during June and July the teams are idle a good deal of the time when work might be done in the fields.

To avoid the necessity of boarding idle mules, and to increase the productiveness of the soil, a change was suggested in this system of cropping, indicated in the following outline: 
Field 1

Corn-70A (Cut for seed (Rye or wheat in Septemfor winter ber.) cover crop.)
Field 2

Soy Beans 50
Field 3

Wheat- $90 \mathrm{~A}$ (Fallow during summer and sow clover in $\mathrm{Au}$. gust or Sep. tember.)

Tobacco-20A Soy Beans 40 (Cover crop ( $\mathrm{H}$ o g g e d as above.) down in $\mathrm{Au}$ gust and September.)

There is no radical change in this system suggested. The rotation scheme remains as before. The main point in the improved plan is the substitution of soy beans for wheat in one field, and a cover crop after corn. The substitution not only gives a better distribution of labour but provides for increased yields by putting another legume into the rotation. The plan also provides for more vegetable matter in the soil by growing a winter cover crop to be turned under before planting soy beans. Hogs do some of the harvesting of the soy bean crop thus saving labour.

As a result of the change suggested it is calculated that about 400 power-units will be saved and about 30 labour-units. The cost to that farm of these power-units would be about $\$ 250$. 
The man labour saved, however, would hardly be worth considering on so large a farm.

Utilisation of Time.-In describing somewhat in detail the problem of reorganisation on this farm it is not intended to recommend a system of farming for any particular locality (since it might be found impracticable), but to illustrate the principles involved in farm organisation. There is suggested also a method for intelligently solving a problem of reorganisation. By means of a chart showing for a given locality when the operations on various enterprises may be done, and the number of labour-units and power-units each operation requires (see Fig. 5 , Chapter V), any one may readily calculate for an individual farm the amount and distribution of labour required. Of course there can be shown only such distribution as would occur under average conditions. The variation in the weather, the failure of certain crops, and changes in prices of commodities to be sold will force changes in any plan previously considered.

In describing the organisation of the types of farms found in several localities where different soil, climatic, and economic conditions pre- 
vail, the reader has observed that no matter how well the available time is utilised and distributed much time is unaccounted for. How does the farmer occupy this time? This is an interesting and important problem. In the corn-belt it has been pointed out that the farmer may use a part at least of the fall and winter months in feeding stock or in dairying. On the hog-farm described a good deal of time was taken up during the winter in tending hogs. In the more southern climates, where the last farm described is situated, some time during the winter months is consumed in ploughing, hauling manure, spreading lime, etc. Much of the time unavailable for field-work is utilised in handling and marketing tobacco. This is no doubt one reason that tobacco is so important a crop in several Southern States. From information available it appears that about one-third of all farm-labour is put on miscellaneous work, such as repairs of all kinds, ditching, hauling, testing and cleaning seed, etc. On the smaller farms the time required by stock is regarded as "doing chores." On the average medium sized farm with 30 to 40 animal units the time occu- 
pied in "doing chores" varies from about two to five hours a day.

The farmer naturally wants to employ his time on enterprises that in the long run pay best; but the time he may employ profitably on such enterprises is limited by physical conditions. When land is cheap and certain staple commodities, like wheat, corn, hay, or cotton, bring a fair price, a reasonably large and profitable business may be carried on without a great deal of diversity. As land becomes higher in price there must be larger profits per acre, and to get these the farmer in most cases is forced to diversify. This explains why in such States as Oregon and Washington the total production of wheat has gradually fallen. The more profitable farms are growing clover for seed, peas and hogs, besides wheat. Economic pressure will force changes in farm organisation resulting in new types. This change in organisation is marked by a corresponding change in area, diversity, intensity of cultivation, and increased yields. The following is an outline of several cropping systems developed near a city and shows how types of farms change as land prices increase: 


\section{OUTLINE OF CROPPING SYSTEMS}

SHOWING THE CHANGES OCCURRING IN TYPES OF FARMS NEAR A LARGE CITY IN CENTRAL WEST

\begin{tabular}{|c|c|c|}
\hline $\begin{array}{l}\text { Value of } \\
\text { land per } \\
\text { acre }\end{array}$ & $\begin{array}{c}\text { Combination of } \\
\text { crops once profitable } \\
\text { nowo disappearing }\end{array}$ & $\begin{array}{l}\text { Combination of crops } \\
\text { now more profitable }\end{array}$ \\
\hline \begin{tabular}{l}
\multicolumn{5}{c}{$\$ 50-\$ 1000$} \\
One to two \\
miles from ciby.
\end{tabular} & 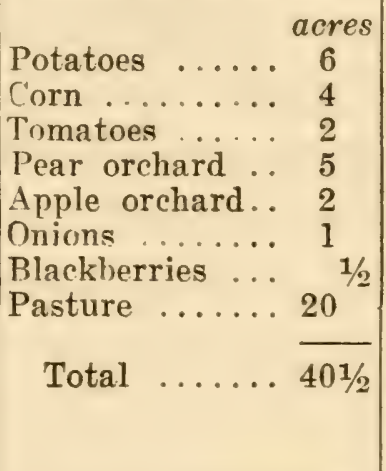 & 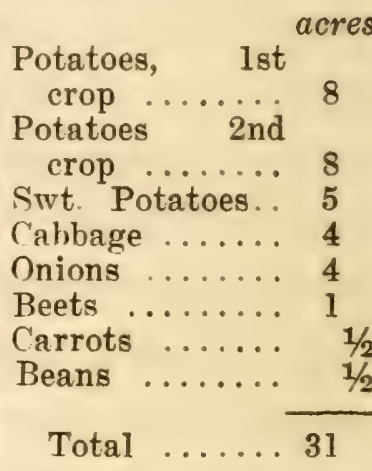 \\
\hline $\begin{array}{l}\$ 300-\$ 500 \\
\text { Good soil near } \\
\text { suburban towns. }\end{array}$ & 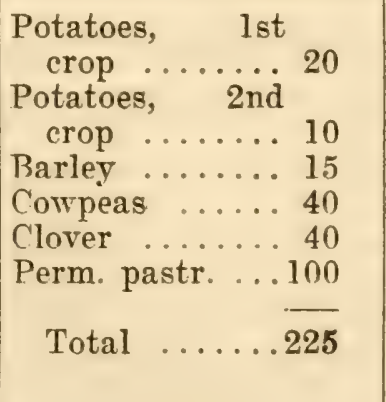 & 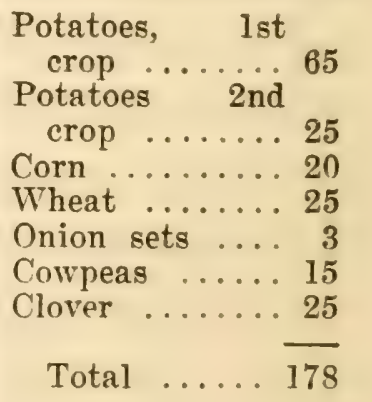 \\
\hline $\begin{array}{l}\$ 100-\$ 300 \\
\text { Fifteen to } 20 \\
\text { miles from city, } \\
\text { but near rail- } \\
\text { road. }\end{array}$ & 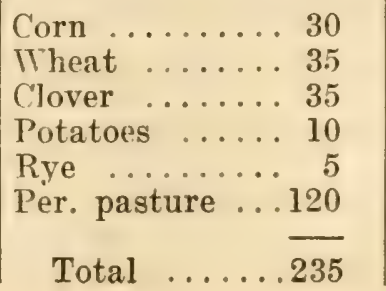 & 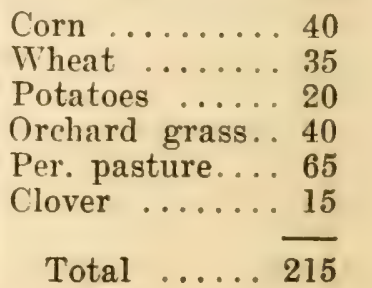 \\
\hline
\end{tabular}




\begin{tabular}{|c|c|c|}
\hline $\begin{array}{l}\text { Value of } \\
\text { land per } \\
\text { acre }\end{array}$ & $\begin{array}{l}\text { Combination of } \\
\text { rops once profitable } \\
\text { now disappearing }\end{array}$ & $\begin{array}{l}\text { Combination of crops } \\
\text { now more profitable }\end{array}$ \\
\hline $\begin{array}{l}\qquad 75-\$ 100 \\
\text { Rather p o or } \\
\text { quality of soil, } \\
\text { but fairly well } \\
\text { located. }\end{array}$ & 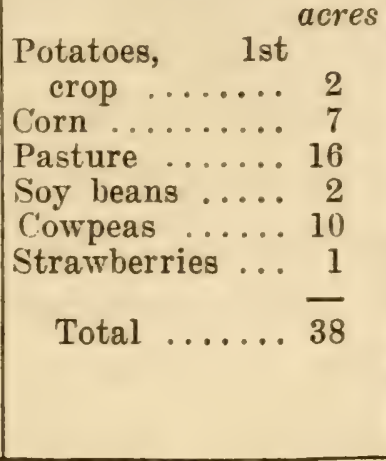 & 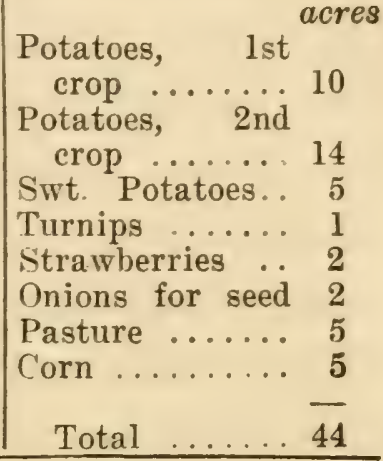 \\
\hline
\end{tabular}

NoTE.-The acreage of each crop increases or decreases to some extent from year to year, according to the farmer's estimate of future prices. On the high-priced land near the city there is often a larger assortment of truck crops and occasionally a greenhouse to grow winter vegetables.

Questions of Size.-Here is shown the tendency toward increased diversity and smaller farms. The ability to control capital and secure labour is the important limiting factor in increasing the size of a business. So the farms become smaller in size as the land increases in value. Each acre of land is required to do more work in order to secure greater profit from it. This is accomplished not only by diversity, which enables the farmer to make better use of his available time, but more crops are grown on the 
same acre, as when late cabbage follows a first crop of potatoes the same year, and between the rows there may be sown kale or spinach to sell late in the fall and in early spring, and to turn under for a succeeding crop. The capacity of each acre to carry a heavier load is also increased by larger applications of fertiliser and stable-manure. This results in more intensive farming. When it becomes economically advantageous to increase further the size of business on a smaller acreage, the greenhouse is used, which requires a large expenditure for glass, heating fixtures, etc. On the most valuable land very little income comes from stock or stock-products except for an occasional poultry or dairy farm.

The type of farm found developing in a definite location today will probably not exist here ten years hence, since the city will have grown, the suburbs moved out further, and new roads and new trolley lines will have been established.

In such States as Iowa, typical of the cornbelt, farms are tending to increase in size. In the type of farms prevailing there it is more practical to increase labour-income by increase 
in area. The four-horse and six-horse teams enabling one man to prepare and plant large crop-areas, the farm grain-elevator that enables rapid unloading, thereby permitting one man and team to husk 80 bushels of corn per day, instead of 60, economic conditions making it more profitable to grow more young stock and thus to increase pasture area-all these combined enable the farmer to increase his income along these lines to better advantage than by greater diversity and more intensive farming.

Three Main Factors.-The foregoing study of farm organisation makes clear three main factors which mark changes in farm organisation, namely, size, diversity, and quality. Under certain conditions the farm organisation shows expansion in one line and contraction in another. Under a different set of conditions the tendency will be in the opposite direction. In the same locality these changes one way or another are going on. The result is that certain types of farms tend to become established and others are disappearing. The farmer must be on the alert for these changes and understand their significance. 
Given a certain type, such as the general farming we see carried on in the great agricultural States, the size of the business is usually increased by increasing the crop-area. This requires capital, and where land is high in price a few added acres mean a rapid increase in capital. When investing a large amount in land the farmer considers the risk on capital invested, the probable rise in value or possible decrease, and the probability of a change in the prevailing type of farming which must affect landvalue. All these factors involve risk. When land comes to be too high in price to warrant the ownership of large areas, other things equal, there will be a tendency to rent instead of to own the land. This is especially true in those places where the farmer is limited to one type of farming, and that a type which requires large area. In such places the tenant-farms will average larger than those owned and farmed. One who owns his land may get a living income from both his capital and his services as manager, while a renter must be limited to his small working-capital invested and what he can make above operating expenses. Recent 
investigations comparing relative investment in land and working-capital show the relation to be approximately: Land, about 84 per cent., working-capital, 16 per cent. The tenant is a capitalist to the extent only of his investment in workingcapital. He must pay his rent to the landlord.

A single farm-unit is limited in size of area. In the most favourable locations where land may be divided into good-sized and regular fields, and where there are no obstructions to machinery, the economic handling of a farmunit cannot extend much beyond possibly 800 to 1000 acres. By a farm-unit is meant the land around a single farmstead where the operator and his hands live. One man, of course, may manage several such units even when separated widely. In the famous blue-grass region of Kentucky the capital invested in single farmunits ranges from about $\$ 5000$ to $\$ 200,000$. The average on the best farms is not far from $\$ 40,000$. The same farm-values will in a large measure prevail in other good agricultural regions. However, the average American who can control capital to the amount of $\$ 75,000$ to $\$ 200,000$ is apt to feel that he can employ it to 
better advantage in other lines of economic endeavour, and in surroundings more congenial or beneficial to his family. A large class of persons in moderate circumstances, whose preference might otherwise be for country life, find that they can command adequate school advantages, conveniences, and moderate luxuries in life only by moving to a town or city. These conditions in a general way limit the size of farm-business that will develop in any section.

Within limits, the size of business may be increased through diversity of enterprises, since it results in furnishing more productive labour on a given area. This is done not only by employing fully available time for field-work, but by selection of such crops as require more labour and give larger returns per acre. Even such staple crops as onions and potatoes, on soil made fertile to a high degree, are planted in rows closer together, besides which the land may yield another crop in the same year.

Diversity results not only when there is an effort to utilise the area farmed and availablo time to better advantage. The diversity of salable products within limits usually results in 
a higher and more reliable farm income. This is probably due to the fact that the farmer takes many chances on the variations in weather and in prices. It is easier for most hunters to kill a bird out of a flock flying swiftly with a shotgun than with a rifle. So far as getting results are concerned it would pay only the expert marksman to use the rifle. There is a common saying that it is not safe to carry all the eggs in one basket, but some one has observed, if there is only one egg to be carried, it is better to have it all in one basket. This principle will apply equally well in farming, since to attempt to start more enterprises than economy would require is disastrous.

Quality in the farm business is shown when the enterprises are selected and handled in such a way as to bring relatively high returns. Quality is closely related also to production, which means relative yielding capacity. A dairy cow may show high quality in the excessively large production of milk and butter fat, or the milk may command a high price merely through cleanliness in handling. One hundred bushels of corn to the acre shows high produc- 
tion or corn may be selected for the feeding qualities and prepared for market in a way to weigh out well and command a high price. Quality is shown in both ways. Within certain limits then the size of a farm business may be increased by working for quality and high production per unit of enterprise.

There are several ways of measuring the size of a farm business, depending largely on the type. In general farming the acreage largely determines size. On a dairy farm the number of dairy cows would indicate the size of the business. On a farm where the enterprises are varied, such as feeding stock, raising corn, wheat, hay, and some tobacco, the number of labour-units required by all the operations would be a practical way to measure the size of business. Thus one farm might require 500 labour-units-about what a successful average farm in the corn-belt would require. A farm with 1000 labour-units would have twice the size of business. The amount of capital invested in land and equipment make good practical standards for most farms. When comparing farms of about the same area and similar in type, it is 
clear that size of business would be correlated with the operating expenses for the year, and that this would be a good indication of size.

The interest that a farmer should have in the study of farm organisation is to understand the principles in such a way that he may apply them in detecting the elements of weakness in the organisation of any farm type. The following chapter will be devoted to a discussion of practical methods of determining farm efficiency.

In the foregoing study of farm organisation it has been shown that economy in farm management results in the development of quite definite relations between the various factors of production and efficiency and the income of the farm. Hence, a study of such relations will show the underlying economic factors in efficient farm organisation. The study of these relations should apply to farms similar in type, otherwise wrong conclusions will be made. For instance, in certain localities where the majority of farms are similar in type, such as the general farm in the corn-belt States or in the cotton belt, labour-income increases about in proportion to the size of farms. In other sec- 
tions, where a change in type of farming is going on and where two or three types have developed, the labour income may be in inverse ratio to the size of farm. Taking each type by itself, however, the income up to a certain point may increase in proportion to the size of farm. For this reason, it is very important in drawing conclusions relative to farm organisation principles to have them apply to similar types. A big jewellery business may be done in comparatively small quarters if well located, while a hardware and machinery business of equal size will require more room. They are different types of business. It is evident that the same principles apply to farming.

The writer was invited out to see a farm near one of the suburbs of a large city and to advise the farmer relative to bringing about a change in the organisation so that it might pay interest on the valuation forced upon it, by the demand for residence property. The farm was about 220 acres in size. No type of farming there could be made to pay, except the type that was developing very rapidly - the potato and truck farm. In order to handle such a type of farm 
successfully in that locality it was necessary to divide it up into smaller units each under separate management. This farm had been the home of the owner's ancestors for many years, so it did not seem agreeable to subdivide it in this way. Sentiment stood in the way of greater efficiency. In this case, the size of capital invested in real estate was much too large in proportion to the receipts that were possible for the type adapted to a large sized farm.

The city man with a suburban home who may have once started out enthusiastically in chicken raising soon learned, if he kept accounts, that the size of flock he could profitably keep was limited by the size of his family. If he had more chickens than could take care of waste vegetables, meal scraps, etc., besides a proper ration of grain, the profits per hen would fall off in a marked degree. This simple economic principle underlies the economic philosophy of farm organisation. Every enterprise, the various classes of working capital, number of labourers, work animals, etc., must be somewhere near the normal proportion found to exist in given types of farming, or the business must lose on account of it. 
The following table shows how important is the size of farms in producing an adequate income. Of the many factors concerned in the profitableness of farming the factor of size of business is probably the most important.

TABLE 8

RELATION OF THE SIZE OF FARM TO THE INCOME ON 273 FARMS OPERATED BY OWNERS IN INDIANA, ILLINOIS, AND IOWA

\begin{tabular}{|c|c|c|c|c|c|}
\hline \multirow{2}{*}{ Area } & \multicolumn{2}{|c|}{ Farms } & \multicolumn{2}{|c|}{ Distribution per acre } & \multirow{2}{*}{$\begin{array}{l}\text { Money } \\
\text { available } \\
\text { for farm. } \\
\text { er's living } \\
\text { if free of } \\
\text { debt. }\end{array}$} \\
\hline & $\underset{\text { ber }}{\text { Num }}$ & $\begin{array}{c}\text { Average } \\
\text { size } \\
\text { (acres) }\end{array}$ & Receipts & Expenses & \\
\hline $\begin{array}{l}40 \text { acres and less. } \\
41 \text { to } 80 \text { acres. } \\
81 \text { to } 120 \text { acres. } \\
121 \text { to } 160 \text { acres. } \\
161 \text { to } 200 \text { acres. } \\
201 \text { to } 280 \text { acres. } \\
281 \text { to } 400 \text { acres. } \\
401 \text { to } 1,250 \text { acres. }\end{array}$ & $\begin{array}{l}32 \\
51 \\
48 \\
44 \\
31 \\
36 \\
19 \\
12\end{array}$ & $\begin{array}{r}37.4 \\
72.9 \\
106.9 \\
149.4 \\
179.1 \\
239.8 \\
321.8 \\
623.8\end{array}$ & $\begin{array}{l}\$ 18.10 \\
17.09 \\
16.22 \\
15.62 \\
18.04 \\
18.12 \\
13.89 \\
16.19\end{array}$ & $\begin{array}{r}\$ 6.98 \\
5.46 \\
6.88 \\
5.80 \\
7.12 \\
6.70 \\
5.07 \\
6.28\end{array}$ & $\begin{array}{r}\$ 416 \\
848 \\
998 \\
1.467 \\
1.956 \\
2.738 \\
2,838 \\
6,182\end{array}$ \\
\hline Total or average & 273 & 178.3 & $\$ 17.25$ & $\$ 6.38$ & $\$ 1,938$ \\
\hline
\end{tabular}

The next table below shows the relation of total capital invested to labour income. The labour income as previously explained is what the farmer gets besides the family living after all expenses including interest on capital have been paid.

In U. S. Dept. Agr. Farmers' Bul. No. 41. 


\section{FARM ORGANISATION}

TABLE 9

RELATION OF THE FARM OWNER'S CAPITAL TO HIS INCOME ON 273 FARMS IN INDIANA, ILLINOIS, AND IOWA

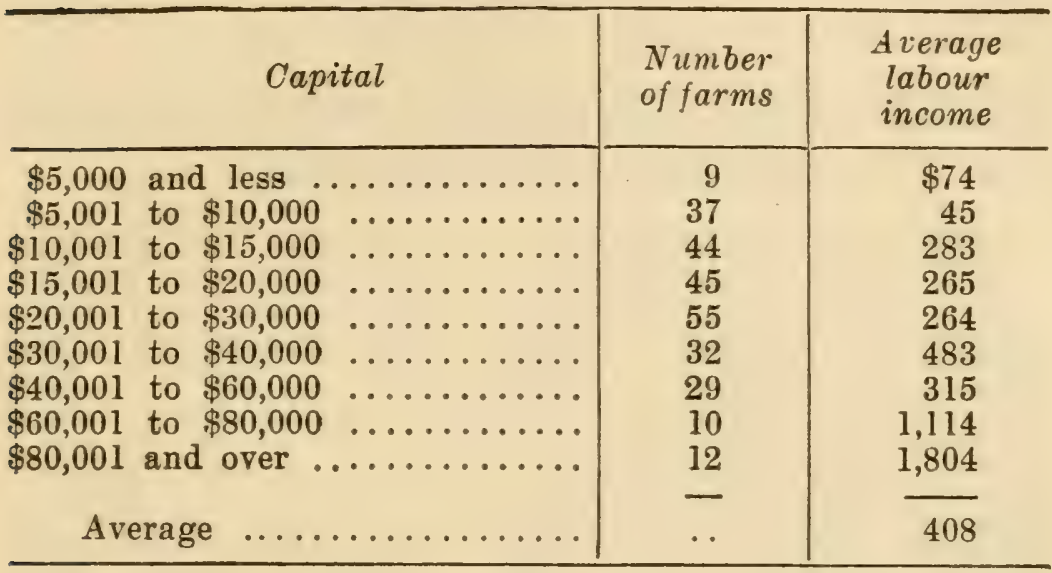

The distribution of capital on farms in various sections of the United States where surveys have been made is shown in the table below. The most important investment is in real estate, followed by live stock.

TABLE 10

PERCENTAGE OF CAPITAL INVESTED IN REAL ESTATE, MACHINERY, LIVESTOCK, ETC.

\begin{tabular}{|c|c|c|c|c|c|c|c|c|c|}
\hline & U. S. & $N . Y$. & Penn. & Mich. & Ind. & Iowa & Ill. & Ore. & Ave. \\
\hline \multicolumn{10}{|l|}{$\begin{array}{l}\text { Real estate, in } \\
\text { cluding build } \\
\text { ings }\end{array}$} \\
\hline \multicolumn{10}{|l|}{ Implements and } \\
\hline machinery .. & 3.3 & 7 & 5.5 & 3.5 & 1.5 & 1.5 & .9 & 2.6 & 3.2 \\
\hline Livestock ... & 13.3 & 15 & 13.7 & 10.7 & 8 & 10 & 7.2 & 7.5 & 10.3 \\
\hline Supplies ..... & $\cdots$ & 4 & 2.5 & 2.6 & 1.6 & 2.2 & 1.4 & 0.2 & 2.0 \\
\hline 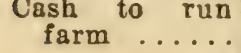 & & & 1.3 & 07 & 0.9 & 09 & 1.2 & 09 & 10 \\
\hline & & & & 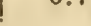 & & & & & 1.0 \\
\hline
\end{tabular}




\section{CHAPTER VIII}

\section{HOW TO MEASURE THE EFFICIENCY OF FARM ORGANISATION}

Successful farming is peculiarly dependent upon favourable weather- and soil-conditions; but however important these natural conditions must be, success seems to be even more dependent upon proper organisation. Many hundreds of records have been taken on farms in different sections of the United States, and these have been carefully studied and analysed, in order to find out the main factors upon which depend success or failure. In one county where such surveys were made the farms with lowest labour-incomes had actually higher average crop-yields. In another county, and in a different region, the successful farms had about the same average crop-yield as did the unsuccessful ones; yet there were farmers in both places who, realising that a statement of their business would show a loss, attributed this loss to low yields on account of 
an abnormally dry year. Thus the results of investigations made in widely scattered areas in the United States tend to confirm the conclusion that high yield of crops is only one of several factors in successful farming.

In the chapter on farm organisation it was shown how, in the effort to economise and prevent waste by means of arranging and combining the enterprises, and by utilising the other resources of the farm, important changes occurred along three main lines; (1) size of business; (2) diversity, and (3) quality of business. Having determined the average size and quality, and the average diversity of the successful types of farms in a locality, these averages may be used as standards for measuring the efficiency of individual farms. Just as there are normal healthy men and women in a community, so we may expect to find normally efficient farms. When the physician is called upon to diagnose a case, the first thing he does is to compare his patient's temperature, respiration, and pulse with the standards of the normal man, thus finding a clue to the disease he is to combat. This method of getting at the seat of human dis- 
eases is quite similar to the proper way of diagnosing a case of inefficient farming. Cato, 2,000 years ago, when giving advice to buyers of farms, said, "When you inspect the farm look to see how many wine-presses and storage-vats there are; where there are none of these you can judge what the harvest is. On the other hand, it is not the number of implements, but what is done with them that counts. When you find few tools it is not an expensive farm to operate. Know, that with the farm as with the man, however productive it may be, if it has the spending habit not much will be left over." This is good sound advice, and a practical, off-hand method for diagnosing the condition of the farm; but the study of farm organisation has given us a more scientific basis for discovering and remedying wastes.

Labour-Income as an Index.-Inefficient farming is shown when the labour-income does not come up to a certain standard. This standard may be determined by taking the labour-income of the average farm in a community, or some arbitrary standard which would be considered fair wages for the work required of a farm manager, 
for instance, $\$ 500$. The following table gives a fair idea of the labour-incomes from farming in widely scattered areas in the United States:

\section{TABLE 11}

SHOWING AVERAGE LABOUR INCOME ON FARMS WIDELY SCATTERED OVER THE UNITED

STATES IN REPRESENTATIVE

AGRICULTURAL SECTIONS 1

$\begin{array}{ccr} & \text { Approximate } & \text { General } \\ \text { Locality } & \text { number } & \text { Average } \\ \text { of farms } & \text { of labour } \\ & \text { incomes }\end{array}$

Three states in corn belt $500 \ldots \ldots \ldots \ldots \ldots \ldots \ldots \$ \ldots 00$

Northern State ...... 400 .............. 511

Middle Atlantic State

(Limestone valley) .. $500 \ldots \ldots \ldots \ldots \ldots \ldots$

South Central State

(Limestone section) . $200 \ldots \ldots \ldots \ldots \ldots \ldots 60$

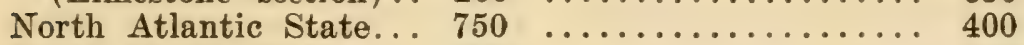

North Pacific State ... 300 ................. 452

Western State (Irrigated

region small farms).

$69 \quad \ldots \ldots \ldots \ldots \ldots \ldots \ldots \ldots 417$

Average Labour Income .................. $\$ 571$

It must be remembered that, in addition to the labour-income, the farmer's family gets a part of their living directly from the farm. This, according to recent investigations, amounts to about $\$ 421$ a year; besides, he gets interest on his investment. In nearly all places where investigations have been made the tenant's labour-

1 These figures are based on the average income of owners and tenants given in U. S. Dept. Agr. Farmer's Bulletin No. 41, and other available data. 
income is considerably larger than the labourincomes of farmers who own their land. The reason for this seems to be that the owner of a farm has, besides the labour-income, the interest on his investment to live on, while the tenant (his capital being relatively small), has but a small portion of his income from interest, and is forced to a greater effort. Labour-incomes above $\$ 5000$ are rare in the lists so far obtained. A very few have approached the ten-thousanddollar mark. Many records obtained show a failure to make even 5 per cent. on the investment, leaving nothing for wages. It is probable that no farmer will continue long in the business, however, unless he makes a fair labour-income besides the market rate of interest on his investment. Such farms must either fall into the hands of more efficient operators, or there must be a change to more successful types.

To illustrate a method of discovering the weak places in farm organisation, we may compare the average of a group of successful farms with the average of a group of unsuccessful ones. The basis of the selection was that all farms showing a labour-income above $\$ 500$ should be 
counted as successful; those falling below to be counted as unsuccessful. The average of the group of successful farms made a labour-income for the year of about $\$ 2,000$. The average of the unsuccessful group had labour-incomes of minus $\$ 50$ - that is, the average farmer of this group lacked $\$ 50$ of paying 5 per cent. interest on his investment. Why these results? In the first place the two groups are similar in type, each having more than $50 \%$ of receipts from live stock, making them live stock farms. They are therefore comparable. In Table 12 these two groups of farms are measured on the basis of the three main efficiency-factors, as stated above.

\section{TABLE 12}

ILLUSTRATING A METHOD OF MEASURING AND COMPARING THE THREE MAIN EFFICIENCY F $\Lambda$ CTORS IN THE

\section{FARM ORGANISATION}

\begin{tabular}{|c|c|c|c|c|c|c|c|}
\hline \multicolumn{4}{|c|}{ Size of Uusiness } & \multicolumn{2}{|c|}{ Diversity } & \multicolumn{2}{|c|}{ Quality of business } \\
\hline$\frac{8}{0}$ & $\begin{array}{l}5 \\
5 \\
y\end{array}$ & 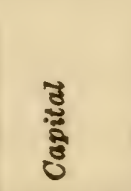 & 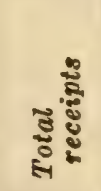 & 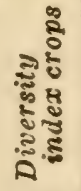 & 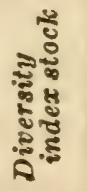 & 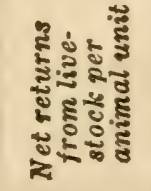 & 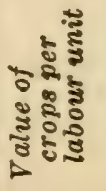 \\
\hline $\begin{array}{l}\text { Successful } \\
\text { Unsuccessful }\end{array}$ & $\begin{array}{l}510 \\
300\end{array}$ & $\begin{array}{r}\$ 44,130 \\
29,580\end{array}$ & $\begin{array}{r}\$ 8680 \\
4515\end{array}$ & $\begin{array}{l}3.04 \\
2.73\end{array}$ & $\begin{array}{l}2.74 \\
2.72\end{array}$ & $\begin{array}{r}\$ 45 \\
38\end{array}$ & $\begin{array}{r}\$ 4.8 \\
4.5\end{array}$ \\
\hline
\end{tabular}

First, it is noticed that the average farm in the unsuccessful group has a smaller area and 
less capital than the average farm of the other group. However, the estimated value per acre is $\$ 15$ higher, showing that the unsuccessful farms are carrying a heavier interest charge.

Diversity Index Defined.-By "diversity" in this table is meant not merely the number of important enterprises undertaken on the farm, but also their equivalent in terms of exactly equal enterprises. Thus, if on a given farm all the sources of income were equal in amount, as $\$ 500$ from corn, $\$ 500$ from wheat, and $\$ 500$ from tobacco, the diversity would be 3 . If these incomes were $\$ 800$ from corn, $\$ 500$ from wheat, and $\$ 200$ from tobacco there would be less diversity, since the incomes from wheat and tobacco would not rank in value with the income from corn. Risks in regard to weather and in regard to the market are not balanced as they are in the first case. The slight difference in diversity indicated in this table is not important in itself, but it suggests that the unsuccessful farms might increase profits by greater diversity, making more intensive use of the land and time available for field-work.

Comparison by Quality.-The next most signifi- 
cant difference to be noted is the lower net returns per animal-unit obtained for livestock, whence the greater part of the income is received. This would indicate clearly that the quality of the livestock business is low on the unsuccessful farms. There is something wrong with the management here, either with buying, selling, feeding, or natural increase. Just which one of these factors is weak, the table does not show. It would be safe to advise farmers owning these farms to examine carefully their whole system of livestock management.

Quality of business, as shown in crop management, does not reveal so significant a contrast; but the successful farms stand a little higher in this respect, getting better returns for each unit of labour spent.

These farms being of the same type, it is a fair measure of successful production, handling and marketing of crops, to compare returns per labour-unit on each class of farms. Table 13 shows in detail the comparison in yield and prices obtained on the average farm of each group. It may be noted that on some crops higher yields and higher prices were obtained on 
the unsuccessful farms; for instance, the yield of tobacco was highest in the unsuccessful group, but a lower price was obtained for this product, which would tend to offset the advantage secured by a higher yield.

TABLE 13

SHOWING YIELD AND PRICES OF SALABLE CROPS ON SUCCESSFUL AND UNSUCCESSFUL FARMS

\begin{tabular}{|c|c|c|c|c|}
\hline $\begin{array}{l}\text { Salable } \\
\text { crops }\end{array}$ & $\begin{array}{c}\text { Yield } \\
\text { successful }\end{array}$ & $\begin{array}{l}\text { Yield Un } \\
\text { successful }\end{array}$ & $\begin{array}{c}\text { Price } \\
\text { successful }\end{array}$ & $\begin{array}{c}\text { Price } \\
\text { unsuccessful }\end{array}$ \\
\hline $\begin{array}{l}\text { Corn } \\
\text { Wheat } \\
\text { Hay } \\
\text { Tobacco }\end{array}$ & $\begin{array}{c}33 \\
: \quad 13.9 \\
111.1\end{array}$ & ${ }_{11}^{33}{ }_{118}^{.98}$ & $\begin{array}{l}\$ 0.68 \text { per bu. } \\
0.921 / 2 \text { per bu. } \\
18.50 \text { per } \mathrm{T} \text {. } \\
13 .\end{array}$ & $\begin{array}{l}\$ 0.681 / 8 \\
0.92 \\
16.50\end{array}$ \\
\hline
\end{tabular}

Effects of Cost.-The expense-bill on a farm may be too high, and too much work may be spent without compensating returns. Economy along these lines is important. The two groups of farms may be further compared on the basis of these factors, as shown in Table 14.

\section{TABLE 14}

COMPARING THE TWO GROUPS OF FARMS ON THE BASIS OF EXPENSE AND LABOUR EFFICIENCY

\section{Successful}

General expenses, per acre ...... \$5.56

Crop acres, per man .......... 28.00

Crop acres, per horse ......... 12.30
Unsuccessful

$\$ 6.53$

24.30

7.70

The expenditures per acre are shown to be greater on the smaller and unsuccessful farms. 
There is certainly a significant contrast in the utilisation of power on these two groups of farms. In both the number of crop-acres per horse is lower than it is found to be on the more successful farms in many other good agricultural sections. Seven and seven-tenths cropacres per horse is very low in comparison with twelve and three-tenths crop-acres per horse. The chances are that horses and mules on the unsuccessful group of farms are idle too much of the time. A great amount of waste may occur on this account, and thus reveal a significant fault in the organisation.

Other measurements might be taken on these farms, revealing the weak places in the unsuccessful group. By a study of the tables, giving the important measurements, one can see where the wastes occur. Seeing these points clearly, possible remedies may be suggested.

Weakness Revealed.-It seems evident that the general livestock farm, devoting a large portion of its tillable area to permanent pasture, must be comparatively large in size to be successful. The smaller farms, developing the same type, will tend to fail. This will be especially true on 
high-priced land. Many of the farms in the successful group had large areas of cheap land which furnished good grazing. The small farms might better increase the crop-area and decrease the acreage in permanent pasture. Their stock-enterprises should consist in feeding, rather than in grazing animals.

The comparing of groups of farms, and showing relations that exist under average conditions, is of little practical account unless it is possible to apply the principles developed to individual farms, enabling one to find out why the individual farm is less successful or more successful than the average farm of the same type. The following table' illustrates a method of analysing the business of an individual farm, and of comparing the main efficiency-factors with those of the average farm. This alone will not tell why such a farm is successful or unsuccessful, but it will give a clue to the weak places in the organisation, after which a more detailed analysis may be made, in order to locate more definitely the places where there is waste. 


\section{EFFICIENCY}

TABLE 15

COMPARING INDIVIDUAL FARMS WITH THE AVERAGE OF THE COMMUNITY

Factors

Size of Business:

Area ............. 300

Capital ........... $\$ 32,712$

Total receipts $\ldots \ldots \ldots \$ 4,215$

No. of productive la-

bour-units $1 \ldots . . . .933$

Animal units per farm.

Labour income ....... \$287

DIVERSITY :

No. of sources of income above $\$ 100 \ldots . .$.

Per cent. of receipts from livestock ...........

QUALITY OF BUSINESS:

Net returns per animal

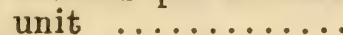

Price per animal unit.. OTHER FACTORS:

No. of men 12 mo. labour

Labour units required per $\operatorname{man} . . . . . .$.

Acres of crops per man.

No. of horses ........

Acres of crops per horse

Total acres per animal unit

Acres of pasture per animal unit ........
14

35

$\$ 45$

$\$ 71$

4

233

22

12

, 8

9

6

$\begin{array}{cc}\text { The } & \text { An } \\ \text { average } & \text { successfionally } \\ \text { farm } & \text { farm }\end{array}$

400

325

$\$ 35,000$

$\$ 7,000$

786

100

$\$ 1,237$

8

12

75

65

772

92

$\$ 2,706$

$\$ 29.518$

$\$ 7,618$

\section{7}

\section{2}

(

$\$ 50$

$\$ 70$

$\$ 48$
$\$ 75$

5

4

193

37

30

12

13

14

10

$4 \quad 3.5$

2.6

2

\section{These farms are similar in type. They have} about the same area, the unsuccessful one hav-

1 By productive labour-units is meant the labour-units required by crops and livestock on the farms. It does not include the miscellaneous labour required for the general farm up-keep. 
ing 207 acres in pasture and the successful one 180 acres. The successful farm raised 8 acres of tobacco; the unsuccessful one 10 acres. The two farms have their crop and pasture areas distributed according to the general plan of the livestock farm. Both are high in diversity, and should be strong in this respect. Probably the unsuccessful farm is giving attention to too many enterprises, thus overdoing diversity. One is struck at once with the low percentage of income from livestock as compared with the average farm and with the successful one. This is of special significance when the low percentage of livestock is compared with the large amount of pasture-land.

The quality of business shows up well on the unsuccessful farm. If a larger amount of livestock were kept on this farm, and the quality kept up, it ought to show an exceptionally high labour-income, but on this farm there are only 33 animal-units. This accounts for the high acreage per animal-unit shown in the table. The successful farm has 92 animal-units, nearly three times as many as are on the unsuccessful farm. This farm is stocked more heavily than the average farm. 
The obvious remedy to be suggested for making the unsuccessful farm more efficient is to carry more livestock, 90 to 100 animal-units. These farms have about the same quality of soil and are equally fertile. In fact the unsuccessful one is valued higher. Crop-area might be increased to advantage and still leave sufficient pasturage. On the average farm 60 per cent. of the farm area is in pasture. A similar distribution on this unsuccessful farm would allow 180 acres in pasture, instead of 207, leaving 27 acres to be utilised by crops. The successful farm has about 55 per cent. of the whole in pasture, somewhat below the average.

In general it may be said that the farmer managing the unsuccessful farm tried, during this one year, to run a tobacco and grain type of farming on a farm planned for general crops and stock-grazing. His difficulty might be said to be similar to that of a man who tried to make a living digging post-holes with a scoop-shovel. A scoop-shovel works all right for shovelling grain or coal, but a different type of implement is required for digging holes in the ground to advantage. Just so in the case of this farmer. 
He should either stock the farm up to its full capacity, or increase his crop-area so that he could utilise the land to advantage with crops.

\section{TABLE 16}

SHOITING METHOD OF COMPARING THE BUSINESS OF AN INDIVIDLAL FARMER WITH THAT OF THE AVERAGE AND THE BEST FARMERS OF THE

SAME COMIUNITY, AS REGARDS LABOR INCOME AND THE FACTORS THAT FNTER INTO FARM-MANAGEMENT DEMONSTRATIONS

\begin{tabular}{|c|c|c|c|}
\hline Items & $\begin{array}{c}\text { Bald- } \\
\text { uin } \\
\text { farm }\end{array}$ & $\begin{array}{c}\text { Aver- } \\
\text { age, } \\
193 \\
\text { farms }\end{array}$ & $\begin{array}{l}\text { Aver- } \\
\text { age, } 25 \\
\text { best } \\
\text { farms }\end{array}$ \\
\hline Labor income ... & $-\$ 45$ & $\$ 190$ & $\$ 750$ \\
\hline Capital $\ldots \ldots \ldots \ldots \ldots \ldots$ & $\$ 4,745$ & $\$ 1,642$ & $\$ 5,923$ \\
\hline Acres in crops $\ldots \ldots \ldots \ldots \ldots$ & 51 & 68 & 93 \\
\hline Number of work horses .......... & 2 & 2 & 3 \\
\hline 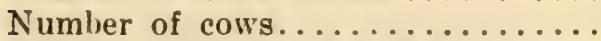 & 11 & 6 & 8 \\
\hline Total receipts (crops and stock) .... & $\$ 715$ & $\$ 763$ & $\$ 1,498$ \\
\hline Receipts from crops ............ & $\$ 12$ & $\$ 25 \%$ & $\$ 014$ \\
\hline 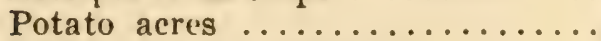 & .2 & 2.3 & 3.4 \\
\hline Y'ield per acre (bushels) .......... & 160 & 90 & 109 \\
\hline Uat acres $\ldots \ldots \ldots \ldots \ldots \ldots$ & 10 & 10.7 & 13.3 \\
\hline Yield per acre (bushels) ........ & 18 & 19 & 24 \\
\hline 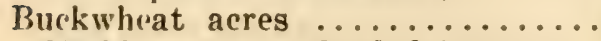 & 7 & 9 & 11 \\
\hline Yield per acre (bushels) ....... & 15 & 15 & 18 \\
\hline 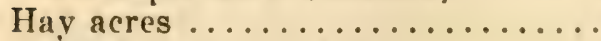 & 27 & 35.1 & 49.3 \\
\hline Yjold per acre (tons) . . . . . . . . . & .9 & .6 & .66 \\
\hline Receipts per cow (milk and butter) & $\$ 30$ & $\$ 44$ & $\$ 62$ \\
\hline
\end{tabular}

"Oach of the farms analysed in an area is visited annuallv thereafter for a number of years to male similar analrses and readjustments in the farm business in order that they may hecone actual demonstrations of the possibilities of increasing the money which a farmer secures from his business by properly organising it. From recent report by C. B. Smith, States Relations Service, U. S. Dept. Agr. 


\section{EFFICIENCY}

The preceding table illustrates a method of measuring the efficiency of an individual farm. This method with variations to suit the locality is commonly used by county agents in the northern States in making an analysis of farms and comparing them with the average and the best of a group. In almost all sections there are successful farms, which may serve for standards of efficiency. 


\section{CHAPTER IX}

\section{BUSINESS METHODS AND PRINCIPLES APPLIED TO FARMING}

In general the farmer is presumed to be unbusinesslike in his methods. This is interpreted to mean that he does not keep a record of receipts and expenses; that he does not make an inventory of his resources at stated times; and that he has no record showing which of the enterprises on the farm are profitable and which are unprofitable. The banker, the dealer in commodities, and the manufacturer, are exchanging money and commodities constantly. In order to avoid utter confusion in such frequent transfers it is absolutely necessary to keep a record of them. Monthly or yearly statements showing the financial relation between debtor and creditor must be issued, and settlements made. While the farmer receives bills showing what he owes his creditors, his business seldom requires him to issue statements calling for settlement of debts; as a rule, only such records are kept as 
seem necessary, as, especially, when several persons are interested in the division of profits from a farm.

Notwithstanding this lack the business-status of a farm is usually pretty well known and items of receipts and expense are kept in mind pretty accurately, so that if definite questions are asked relative to the various items and factors entering into the farm organisation and business an approximately accurate record may be obtained, for at least a year. In this way most of the data relating to farm-management have been obtained.

Utility of Records.-The keeping of certain records would undoubtedly be of great value on every farm. Certain records might be kept for a definite period, in order to get the information wanted when other records might be begun. Probably no farmer would be repaid by keeping complete records of business transactions. When, however, the keeping of records becomes a habit the time required is insignificant. By actual experiment in keeping simple, but quite extensive farm-records, the work was found to require but about five minutes a day. 
A SIMPLE METHOD OF KEEPING A RECORD OF RECEIPTS AND EXPENDITURES

\begin{tabular}{|c|c|c|c|c|c|}
\hline 1911 & & \multicolumn{2}{|c|}{ Received } & Paid & Out \\
\hline July 17 & 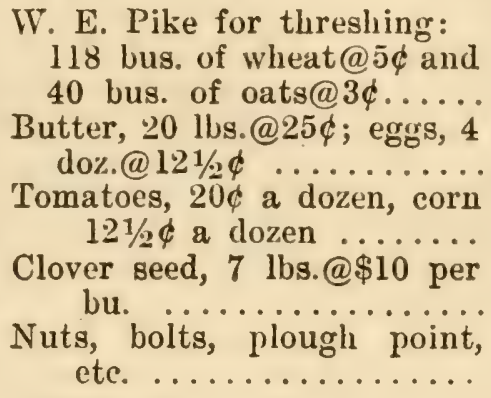 & $\begin{array}{c}\$ 5 \\
1 \\
\ldots\end{array}$ & $\begin{array}{l}\cdots \\
50 \\
97 \\
\ldots\end{array}$ & $\begin{array}{r}\$ 7 \\
\ldots \\
\cdots \\
1 \\
6\end{array}$ & $\begin{array}{c}13 \\
\ldots \\
\ldots \\
43 \\
66\end{array}$ \\
\hline
\end{tabular}

This form keeps a record or journal of items of expenses and receipts. It may, as in this record kept by a farmer, show the price of things sold and rate of payment for services. If a farmer is interested simply in the record of receipts and expenditures, this is the most simple form.

Every farmer should keep a simple record of receipts and expenditures, besides the account with his bank. The foregoing record of receipts and expenditures for a month on a farm shows a good form for keeping such records. Such a record enables a farmer to look up any transaction and to know when it occurred. At the end of the year he is able to calculate quickly the sum of his receipts and of his expenses. If, besides this, he had inventories taken at the begin- 
ning of the farm's business-year, and again at the end of the year, the income could be readily determined. The following example of such inventories shows how simple the records and determinations may be.

TABLE 18

SHOWING AN INVENTORY ON A FARM

\begin{tabular}{|c|c|c|}
\hline Item & $\underset{1913}{\text { March } 1,}$ & $\underset{1914}{\operatorname{March} 1,}$ \\
\hline Value of farm (including buildings)... & $\$ 2500$ & $\$ 2500$ \\
\hline Implements and other small equipment & 462 & 520 \\
\hline Work horses, three .............. & 375 & 375 \\
\hline Hogs: & & \\
\hline 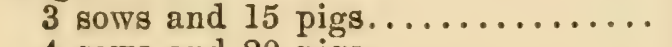 & 135 & \\
\hline $\begin{array}{l}4 \text { sows and } 20 \text { pigs.............. } \\
\text { Cows: }\end{array}$ & $\cdots$ & 150 \\
\hline 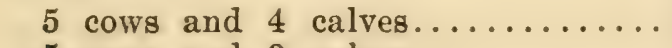 & 310 & \\
\hline 5 cows and 3 calves............. & & 300 \\
\hline Sheep : $9 \ldots \ldots \ldots \ldots \ldots \ldots \ldots$ & 36 & 36 \\
\hline Chickens: & & \\
\hline 5 dozen $\ldots \ldots \ldots \ldots \ldots \ldots \ldots$ & 30 & \\
\hline 8 dozen $\ldots \ldots \ldots \ldots \ldots \ldots \ldots \ldots$ & 7 & 40 \\
\hline Growing crops (labour and material). & 100 & 150 \\
\hline Feed and supplies $\ldots \ldots \ldots \ldots \ldots \ldots$ & 175 & 115 \\
\hline Cash on hand and in bank, notes, etc... & 500 & 925 \\
\hline Total resources. & $\$ 4623$ & $\$ 5111$ \\
\hline Notes and bills to be paid .......... & 65 & $\cdots$ \\
\hline Net value of inventory $\ldots \ldots \ldots \ldots \ldots$ & $\$ 4558$ & $\$ 5111$ \\
\hline \multirow{2}{*}{ Gain for the year $\ldots \ldots \ldots \ldots \ldots$} & 553 & - \\
\hline & $\$ 5111$ & $\$ 5111$ \\
\hline
\end{tabular}

A statement such as this shows what the farm has earned during the year. The best time to make an inventory is when the crops and other products are mostly sold, or when there is the least amount of stuff on hand the value of which needs to be estimated. 
Many farmers as well as others find it convenient and sometimes necessary to keep a cashaccount, that is, a record of cash received and expended. A cash-account enables one who is responsible for a certain amount of cash received to determine quickly at any time the amount on hand, when, by making a balance, he can show whether the cash in hand, actually counted corresponds with the balance shown by the difference between the cash received and that spent. It is an excellent plan for children on the farm or elsewhere to be trained to account for cash received in this way. The following form illustrates the method of keeping such accounts.

TABLE 19

SHOWING FORM FOR SIMPLE CASH ACCOUNT

\begin{tabular}{|c|c|c|c|c|c|}
\hline 1914 & \multirow[b]{2}{*}{$\begin{array}{c}\text { Drew on deposit in } \\
\text { bank }\end{array}$} & \multicolumn{2}{|c|}{$\begin{array}{c}\text { Cash Received } \\
(D r .)\end{array}$} & \multicolumn{2}{|c|}{$\begin{array}{l}\text { Cash Spent } \\
(\text { Cr. })\end{array}$} \\
\hline Jan. 4 & & $\$ 50$ & 00 & & \\
\hline 15 & $\begin{array}{l}\text { Paid Henry wages. } \\
\text { Oil for engine }\end{array}$ & $\cdots$ & . & $\$ 10$ & $\ddot{00}$ \\
\hline 20 & Repairs for binder & $\ddot{0}$ & $\because$ & 1 & 40 \\
\hline 24 & $\begin{array}{l}\text { One ton cotton seed } \\
\text { meal }\end{array}$ & & & 30 & 00 \\
\hline 25 & $\begin{array}{l}\text { Cash for calf } 6 \\
\text { wks. old }) \ldots\end{array}$ & 10 & ${ }_{00}^{\cdots}$ & & \\
\hline 27 & Deposited in bank & . & .. & 10 & 00 \\
\hline
\end{tabular}




\begin{tabular}{|c|c|c|c|c|c|}
\hline \multirow[b]{2}{*}{ Feb. 1} & \multirow[b]{2}{*}{ 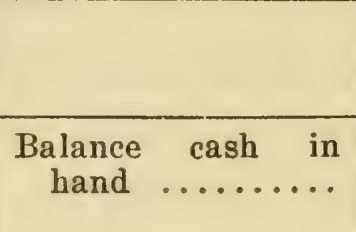 } & \multicolumn{2}{|c|}{$\begin{array}{c}\text { Cash Received } \\
\left(D r_{0}\right)\end{array}$} & \multicolumn{2}{|c|}{$\begin{array}{l}\text { Cash spent } \\
(\text { Cr. })\end{array}$} \\
\hline & & $\frac{\cdots}{\$ 60} \frac{}{\$ 8}$ & $\frac{\ddot{0}}{\frac{00}{10}}$ & $\frac{\frac{8}{\$ 60}}{\ldots}$ & $\frac{\frac{10}{00}}{\cdots}$ \\
\hline
\end{tabular}

This form of account enables one to keep track of the cash carried around in the pocket or kept in the house. A balance may be made at any time to ascertain whether all receipts and expenditures have been accounted for, and no money lost. The stubs of the bank-checkbook will show the balance in the bank. The two accounts together will tell at any time just how much eash is available.

Keeping Accounts with Crops.-Should the farmer wish to know what different classes of expenditures on the farm were costing he could group the items of expense from the daily record into such classes as repairs, labour-expenses, fertiliser-expenses, etc. The same thing could be done with receipts.

Sometimes it is found convenient to keep an account with a labourer on the farm, or with some other person with whom business dealings have been developed. In such cases the person concerned is frequently receiving things of value, and at the same time may be giving his 
labour, or other things, or services, which have value. Some convenient and accurate method is needed of determining at any time just what settlement should be made between the parties concerned, and the following form is commonly used for that purpose.

TABLE 20

AN ACCOUNT WITH THE HIRED MAN

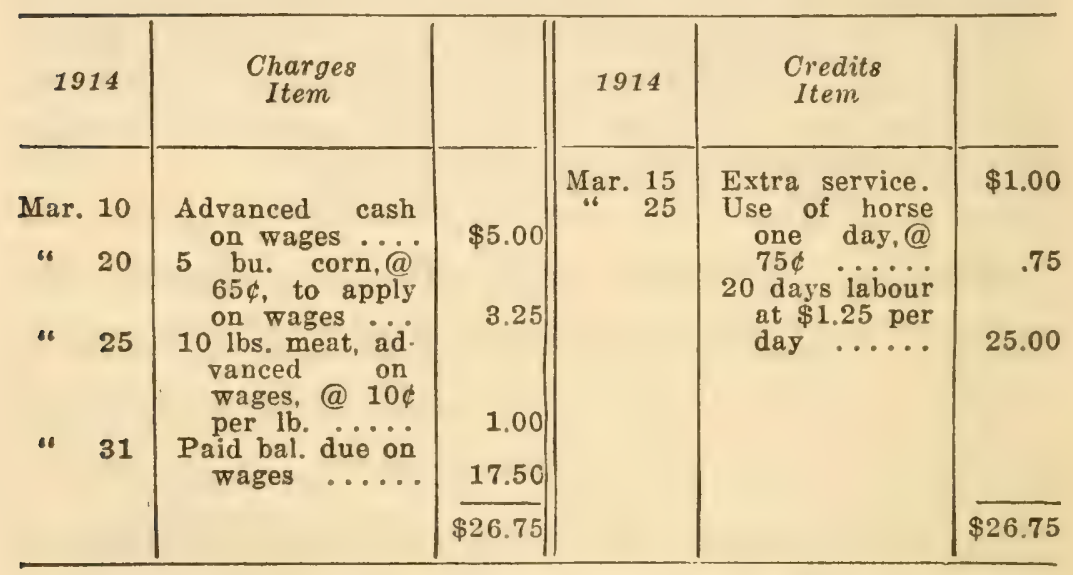

In this case a settlement was made at the end of the month, when $\$ 17.50$ was due the hand on wages, which the farmer either paid in cash or by check. Such accounts may be kept on a card, in a book or on a ruled slip of paper.

This same form of accounting may be used to show the profitableness or unprofitableness of any enterprise on the farm, such as a corn-crop, a dairy, sheep, or poultry enterprise. The en- 


\section{BUSINESS METHODS}

TABLE 21

AN ACCOUNT WITH A 20-ACRE FIELD OF CORN

\begin{tabular}{|c|c|c|c|c|c|}
\hline 1914 & $\begin{array}{l}\text { Charges } \\
\text { Item }\end{array}$ & $\Delta m^{\prime} t$. & 1914 & $\begin{array}{l}\text { Credits } \\
\text { Item }\end{array}$ & $A m^{\prime} t$. \\
\hline Eeb. 20 & 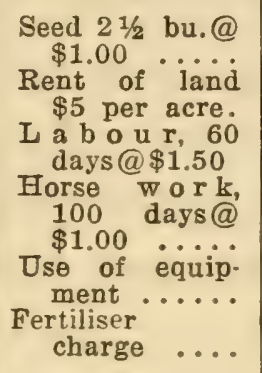 & $\begin{array}{r}\$ 2.50 \\
100.00 \\
90.00 \\
100.00 \\
25.00 \\
10.00\end{array}$ & $\begin{array}{l}\text { Dec. } 4 \\
\text { June } 5\end{array}$ & $\begin{array}{l}\text { Sold 320@55 ... } \\
\text { Sold } 500 @ 60 \phi . . \\
\text { Fed stock balance, } \\
180 \text { bu. valued } \\
\text { @60\%...... }\end{array}$ & $\begin{array}{r}\$ 176 \\
300\end{array}$ \\
\hline & $\begin{array}{l}\text { Total charges } \\
\text { Gain }\end{array}$ & $\begin{array}{r}327.50 \\
256.50 \\
\$ 584.00\end{array}$ & & Total credits. & $\$ 584$ \\
\hline
\end{tabular}

This form of accounting shows what the crop is yielding in the way of direct net income. In the farm organisation some crops may indirectly increase the total income, but this will not appear in such an account as this.

terprise is credited with what it yields in the way of income to the farm, and charged with all expenses, such as labour, machinery, fertiliser, rent, etc. When a part or all of a certain crop is fed to stock, or transformed into some other product, an account is opened between the crop and the stock to which it may be fed, or with the product into which it may be transferred.

While cost-accounting of this kind is often of value to the farmer who may find it im- 
portant to measure the relative profitableness of each venture on the farm, the results obtained may be very misleading unless rightly interpreted. It must always be taken into account that the enterprises on a farm are related to each other as parts of a system. They have been selected consciously or unconsciously to constitute a farm organisation, and from this point of view the net profit on any single enterprise will not alone measure the importance of such enterprise as a part of the organisation. Take, as an illustration, the feeding of steers on a farm in the South-central States, which the writer has had occasion to study. The basic crop-rotation on the farm is corn, wheat and clover. As a rule the clover occupies the field alone one year, and is then turned under for a corn-crop. The corn is fed to steers which are usually bought in a neighbouring State. An account with the steers, charging them with the corn and other feed at market prices, shows but a slight profit. The operator of the farm, however, makes a satisfactory labour-income, and he is probably correct in regarding the steerfeeding enterprise in relation to the farm-organ- 


\section{BUSINESS METHODS}

isation as a profitable enterprise. The average production of corn on this farm is about 50 bushels an acre, nearly 100 per cent. above the average for the region. The feeding of steers fits in well with such a rotation, is an important factor in the distribution of labour, and the system as a whole has increased greatly the capacity of the soil to produce large yields of corn, wheat and clover. No other system has been developed in that part of the country to produce similar results.

Indirect Benefits.-Over a large area of good agricultural land in the Eastern and South-central States, wheat has held for many years, and still holds, an important place in the crop-rotation, while the farmers themselves have known and are advised through agricultural literature that the crop considered by itself is not profitable. The operators of the farms have discovered, however, no other crop-enterprise more profitable from the point of view of the farmorganisation as a whole. These facts show that single enterprises are so related to the organisation as a whole that the measure of the net income from each determines only partly its ef- 
ficiency in the combination of enterprises. Where the corn-crop or tobacco-crop has had a well-prepared seed-bed, and has been thoroughly cultivated, thus eliminating weeds, conserving moisture, and leaving the land in a good physical and sanitary condition, the wheat-crop that follows has been benefited. The fertiliser sown with the wheat-crop benefits the clover, grass, and corn which follow. Manure spread on the pasture-field or meadow benefits not only the grass and clover, but by stimulating the growth of these crops supplies more roots to the soil and more vegetation to turn under, thus increasing the productive capacity of the land. The value of a crop then is partly its function in making efficient and profitable the whole organisation.

It has already been shown how livestock on most farms is profitable because it utilises products that otherwise would be largely wasted. On most farms straw and corn-stover would, as a rule, have little value unless utilised by stock.

On a certain large farm it was considered important to have a record of the distribution of 
labour on various crops, so the following form was worked out and found to be practical:

\section{TABLE 22}

DAILY LABOER RECORD SHEET FOR A FARM

Date: September 14, 1914.

\begin{tabular}{|c|c|c|c|c|c|c|c|}
\hline Operation & $\begin{array}{c}\text { Field } \\
\text { No. }\end{array}$ & Crop & $\begin{array}{l}\text { Man } \\
\text { Hrs. }\end{array}$ & $\begin{array}{c}\text { Team } \\
\text { Hrs. }\end{array}$ & $\begin{array}{l}\text { En. } \\
\text { gine } \\
\text { Hrs. }\end{array}$ & Crew & $\begin{array}{c}\text { Remarks } \\
\text { on } \\
\text { weather, } \\
\text { etc. }\end{array}$ \\
\hline $\begin{array}{l}\text { Disking .... } \\
\text { Harrowing . } \\
\text { Drilling .... } \\
\text { Cutting } \\
\text { sprouts .. } \\
\text { Repairing } \\
\text { drill ...... } \\
\text { Miscellaneous }\end{array}$ & $\begin{array}{l}2 \\
9 \\
9 \\
19 \\
\cdots \\
\cdots\end{array}$ & $\begin{array}{c}\text { Barley } \\
: \\
\text { Pasture }\end{array}$ & $\begin{array}{r}8 \\
4 \\
10 \\
90 \\
10 \\
5\end{array}$ & $\begin{array}{l}28 \\
12 \\
40 \\
\ldots \\
\ldots \\
\ldots\end{array}$ & & $\begin{array}{l}2-7 \\
1-3 \\
1-4 \\
9-0 \\
2-0 \\
1-0\end{array}$ & Clear \\
\hline
\end{tabular}

A record like the above is made for each work day of the year by the manager of the crop-enterprises. The manager of the stock makes a similar record. The bookkeeper may occasionally enter these labour charges in the accounts with fields or crops. The figures in the column under "crew" means that two men and seven horses, etc., were engaged in discing.

The farmer should not attempt to keep accounts without some definite end in view, and without knowing some use he can make of them, for just the same reason that he should not waste his time in doing any other kind of unnecessary work.

Returns on Investment.-The farmer is necessarily capitalist, labourer, and manager com- 


\section{FARM MANAGEMENT}

bined. When the size of his business is large capital becomes a very important factor. Men are presumed to be guided by business principles and it is a fundamental economic principle that capital seeks investment in such enterprises as are most profitable, considering risk, the convenience and cost of realising cash and other factors recognised as important in business. In three States ${ }^{1}$ of the corn-belt, the average rate of interest which 247 landlords received on average capital of $\$ 25,210$ was 3.5 per cent. On a selected list of about 200 farms in an exceptionally good agricultural region the average farm, after allowing $\$ 800$ for manager's services paid 5.3 per cent. on an investment of about $\$ 40,000$. That is, if this farm were owned by a corporation issuing stock, the manager could have been paid $\$ 800$ and 5.3 per cent. dividend declared. This probably represents about what the best general farms are doing.

During the past twenty years, both in the cornbelt and in other good agricultural districts, the value of land has much more than doubled in value. This fact would naturally cause these

1 Farmers' Bulletin U. S. Dept. of Agriculture 117, p. 12. 
lands to have a "speculative" value-that is, a value based on the expectation that if a farm is purchased it will continue to advance in value per acre. When such conditions exist, it would be expected that interest calculated on the estimated value of the investment would be low in comparison with such investments as ordinary farm-mortgage loans.

Advantages of Ownership.-There is a point where the average farmer will be forced off his farm through economic necessity. This will be when his labour combined with his capital will not support him and his family. Thirty thousand dollars invested in a farm business yielding 5 per cent. will keep a large family in luxury compared with a similar income in the city, owing to the addition of that part of the living which comes directly from the farm. Probably no other form of investment could be made as secure and in the long run as profitable. Most normally constituted persons doubtless feel instinctively the risk of the speculative occupations, and really prefer to use their money in productive enterprises which do not offer chances to win large fortunes, but which yield 
such profits as are reliable, and which allow the feeling that a man has earned his money through some worthy achievement rather than through luck or chance.

Ownership of land seems to make most persons feel more secure, and gives them a sense of dignity and importance that no other form of investment gives. This is not wholly a matter of imagination. The individual is simply responding to the community or race feeling. The man who owns real estate is generally believed to be a more stable and reliable citizen. He feels stronger in his influence as a citizen, and the fact that this condition exists really strengthens his influence and his credit. All such factors have to be taken into account in the attempt to account for the farmers' business sense in dealing with capital. These facts must also be taken into account when measuring the success of the farmer. A farmer is certainly not successful in his business if he fails to earn on his investment what he could get by investing in such securities as government bonds, besides wages commensurate with his abilities. Every man owes it to the community which furnishes 


\section{BUSINESS METHODS}

him his opportunities, and to the nation protecting him, to give the best services possible, whether it be in farming or in any other honourable occupation, and it is due him to be paid according to what he may be able to achieve.

Public Spirit.-The investment of money in public improvements, and in enterprises that only indirectly bring profit to the individual carrying on a business, is a business principle which farmers as a class are slow to grasp. The discussion of good roads, farmers' insurance, farmers' shipping associations, farm bureaus, and co-operative undertakings of various kinds, belongs primarily to the field of rural economics, but these institutions have a close relation to the successful operation of a farm. Money invested to support them, and time spent in developing and maintaining them, can be shown in many instances to increase the profits in farming.

In a locality where the growing of Irish potatoes is the basis of farm-organisation, two well organised produce exchanges are organised and supported by farmers. One of these exchanges has existed for many years, and is well known 
over a large part of the United States. The climate and soil of this region are not specially adapted to growing Irish potatoes-in fact many places in the same State have better physical advantages; but owing to the fact that an efficient business organisation has been developed to handle the marketing of potatoes the farmers find this crop on the whole the most profitable of farm enterprises.

It is a fundamental principle in business, and a principle adhered to by all successful business men, to buy the best material and equipment used in the business at as small cost as possible; likewise, to pay only for actual services rendered. On the basis of such principles the farmer is justified in patronising only such institutions as render him profitable service. It is his duty as a citizen to help organise the business mechanism of his community on the basis of economy. The farmer cannot be both a successful farmer and banker, hardware-man and grocery-man but he may under certain conditions wisely and profitably invest his money with others in these enterprises, and have a hand in organising them in a way to serve the com- 


\section{BUSINESS METHODS}

munity to best advantage. As long as the farmer confines his interests to his own individual farm there is little hope that he can claim a just share in the distribution of wealth, or be trained to profit by advantages in co-operation. In nearly all the most prosperous farming communities in the United States farmers are investing their money in such local institutions, and in this way are becoming a factor in the reorganisation of business on the basis of public economy. 


\section{CHAPTER X}

\section{FARM ADMINISTRATION}

FARMING is usually regarded as a business in which carefully worked out plans are of little practical value. It is the general opinion also that the farmer, more than any other producer, follows the rules and practices of his father, with little consideration of scientific principles. These contradictory ideas are in reality both based on the same fundamental truth. The fact that a majority of farmers follow out, year after year, a plan developed by their ancestors, and even have to be forced to follow new methods by dire necessity, would seem to show that farming more than any other line of production depends upon planning and calculation.

Farm administration deals specially with the practical application of the principles of farm organisation to the details of farming.

Work and Weather.-Farming according to a plan or schedule, does not mean that in any one 
year the work planned for a certain season may be done in a definite order, or on the particular day indicated by the plan. If a plan were made out with such intention it would be very faulty indeed. A farm-plan should show the amount of work and the season in which such work should normally be done. Only in a general way can it be predicted what the character of the days followed in the period will be. A weather-chart will show whether they will be normally wet or dry, cold or hot. We can predict how long the working-hours may be. We know that certain operations must come within the period or not be done at all. Nature has determined the seasons, and the adaptation of farm-enterprises to them. It is the business of farm management to find out how these enterprises are related to the seasons, so that they may be combined in such a way as to use the time to best advantage. Working to a plan implies a certain amount of control of conditions. Too many farmers are passive in their attitude toward natural forces and in their dealings with them. Up-to-date methods in all lines of work are based primarily on the presumption of the 
control of natural forces. Farming, to be successful, must be done with the same presumption and the same confidence.

The farmer, who is "getting on," will rarely blame the failure of crop-yields entirely on the weather, or fret much about the possibilities of what it may be in the future. He will be found busy doing the work demanded by the various enterprises as they develop in season. Complete and workable plans for the operation of a farm provide for accident and abnormal states of the weather. The number of operations required under normal conditions may be reduced or increased according to the condition of the soil or state of the weather. Certain operations are done only when the soil conditions are $a b-$ normal. Thus farmers, for certain crops, roll the land only to break clods or to bring moisture to the surface by capillarity to be available for seed planted or for shallow rooted plants. Heavy clay soils can safely be ploughed only when the soil is well drained or when it has a chance to freeze and thus avoid the damage that may result when wet. The farmer who is accustomed to wait for a favourable season in 
which to plant a crop, or until the moon is in the increasing or decreasing phase, is likely to get behind in his work. Often the whole business for the year is completely disorganised. The rotation-plan is thrown out of gear, and the year's operations result in disaster.

The farmer, however, who is systematic in his work, who has measured the amount of work his organisation requires and has planned ahead for emergencies is pretty sure to come out ahead in the game of farming during the most unfavourable year.

In order to illustrate how the farm work for a year or more in advance may be planned and stated in a more or less definite form, two workschedules follow. The work schedule for a general farm shows the periods within which the operations are usually done. The available days for work will vary with the time of year. The farmer will probably not be able to do the work just as it is scheduled since the weather usually varies a great deal from the normal and other things interfere also, but such a schedule states the farm problem for the year in a way that will help greatly in the practical organisa- 


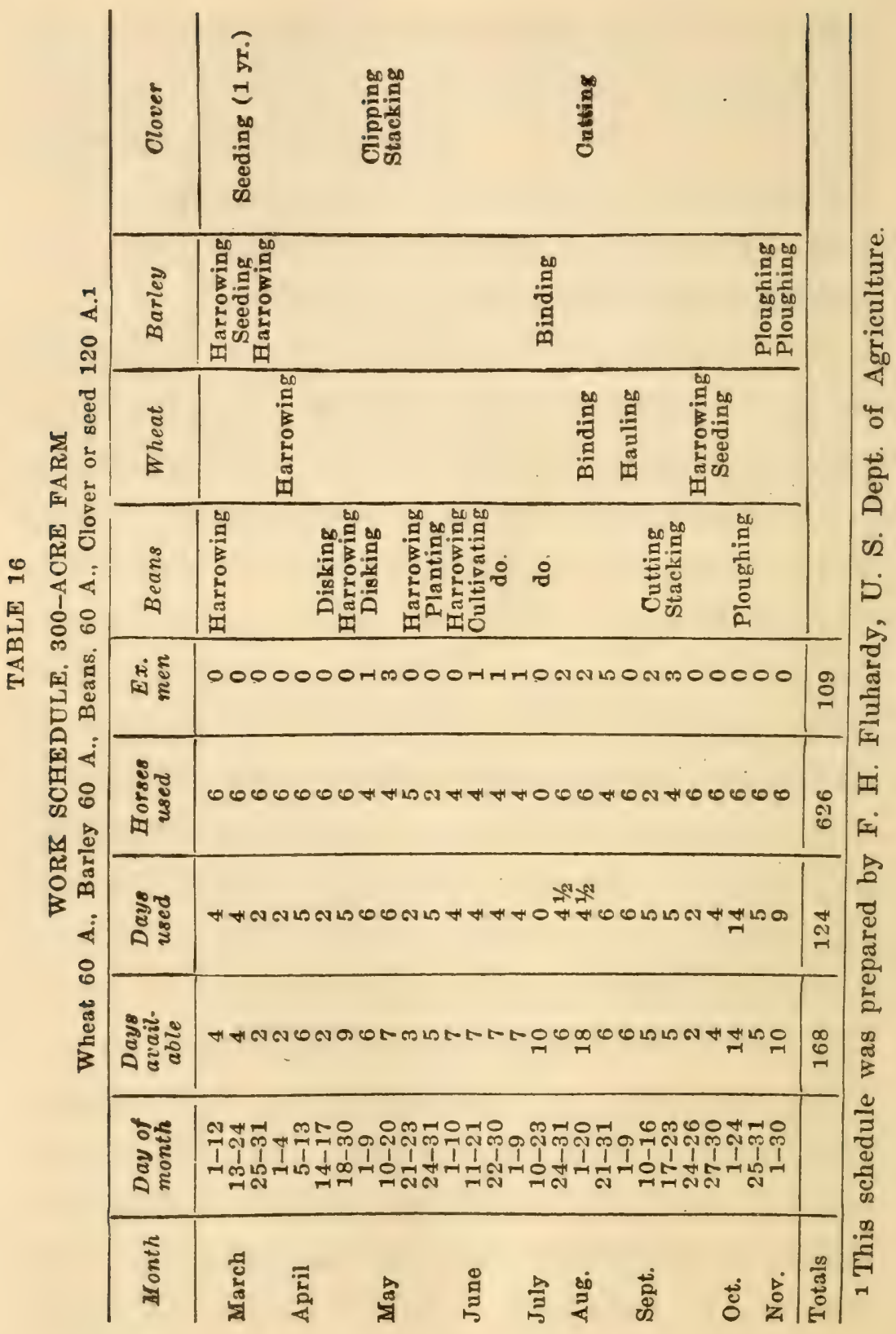


tion of the work in hand and in meeting new problems as they turn up. Oftentimes by putting down in concrete form the work that must be done, one is enabled to see profitable changes to be made. In the case of the general farm there are 44 available days which will probably not be needed in the field work. The farmer might wish to plan to make profitable use of this time.

The work schedule for a strawberry enterprise shown below is meant to show the order of the operations to be performed, the seasons for doing them, various crews used, implements, and the cost in days' work for men and teams. Such a schedule would be valuable not only for the manager of such an enterprise but for any one thinking of going into the business of raising strawberries.

A certain farmer was once advised by his enterprising neighbour to begin to put up his ice for the summer. The season was getting late and on account of an abnormally mild winter the ice was not yet in an ideal condition to put up. The farmer replied that if the Lord intended that he should have ice for the summer He would 


\section{TABLE 17}

WORK SCHEDULE FOR OPERATING A STRAWBERRY FIELD FROM THE PLANTING TO THE END OF THE PERIOD DURING WHICH THE PLANTS HOLD THE GROUND-IN A SOUTH CENTRAL STATE

\section{FIRST YEAR}

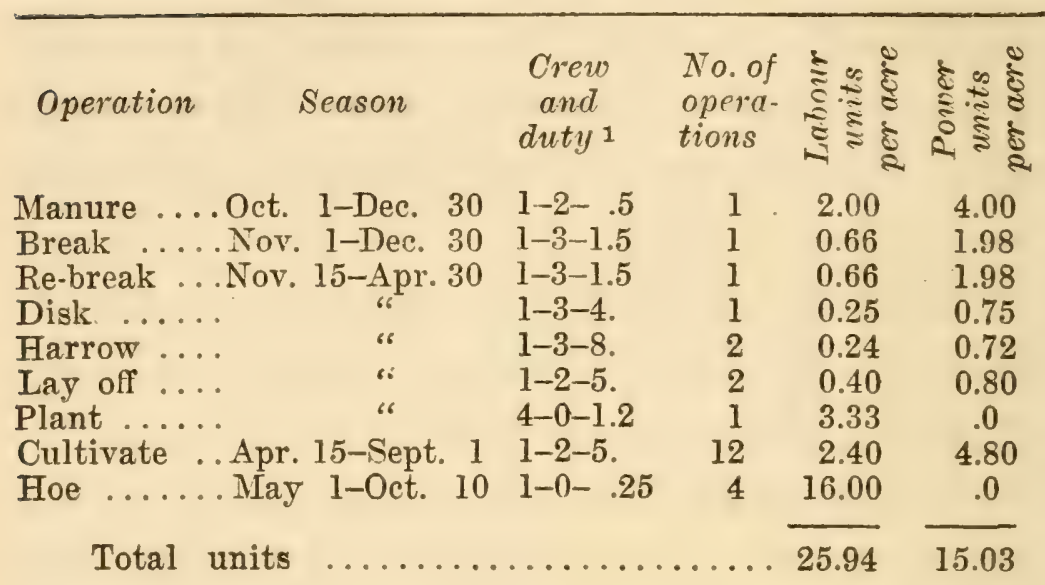

SECOND YEAR

Mulch ....Feb. 1-Apr. I. 2-2-2.

Pick ....... May 15-June 10 1-0-.03

Pack and

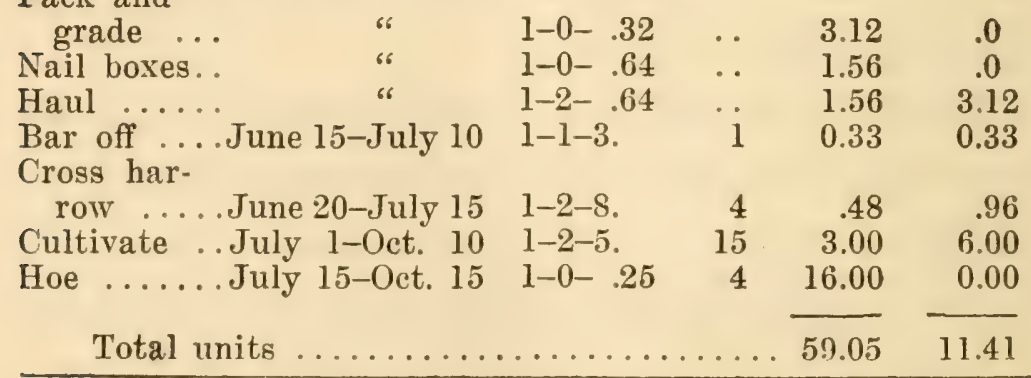

The second year's operations are duplicated the following year, while the plants hold the ground 3 to 4 years.

1 1-2-.5 means a crew of one man and two horses do .5 acres per day. The rate of picking is based on 160 crates per acre. 
see that it was in the right condition to put up. This is the attitude of mind of thousands of farmers passively submitting to adverse conditions.

The Farm Operator.-The farm operator is the person who runs the farm. Usually he is both the organiser and administrator of the business. The operator may rent the farm or own it. The term landlord is used to indicate the relation between the owner of a farm and the person who rents it. In most cases of renting land the landlord specifies certain conditions relative to the plan according to which the farm is to be operated. The owner of the land should not want his land to lose in productive capacity and value of general equipment such as fences, drains, buildings, etc. He may then specify that a certain rotation shall be followed, that a certain amount of manure, fertiliser, or lime, shall be applied at stated times, preceding or following certain crops. In this way the landlord assists in planning the farm organisation, but leaves the task of administration to the one who rents it.

In most farming districts of the Northern 
States the renter or tenant on a farm is a farm operator. He rents the land for a year or a term of years, and pays cash or share-rent. He usually furnishes the entire working capital, and operates it in the same manner as if he owned it. In the South-central and more southerly States there has developed a different condition relative to renting land, managing labour and operating the farms. These conditions have been pointed out and explained in Chapter I.

Operator and Labourer-Cotton and tobacco are important crops in that region and require special attention during a large part of the year. Much of the labour connected with these crops can be done by women and children. Negroes do most of the labour on cotton and tobacco there, so that it has come about that a distinct labouring-class exists, while in most other parts of the United States no distinct agricultural labouring-class has developed.

In cotton and tobacco districts the farm operator adjusts his organisation to the conditions that exist. Many of the labourers upon whom he depends to work the land live on his farms. 
The more prosperous of them may own a single work animal or a team. Some own a small area of land which they till as a garden or small farm. These people make their living by hiring out to farm operators as regular or extra labourers, or they may be employed to "crop" a small area of land. In such cases the operator may furnish all or only part of the equipment. In some cases the one who does the cropping furnishes the entire equipment, in which case he more nearly approaches to the status of a tenant in the Northern States. Even in this case he seldom acquires control of the land for a year or term of years. His function is simply to "make" the crop on a specified piece of land, and when such crop is removed the land is utilised by the operator in the same manner as if he had raised the crop himself. These are known as "croppers" or "share-tenants," or in some localities, "renters." As a rule the renter is one who is a farm operator, who organises and operates an entire farm-plant for a year or more.

These distinctions are made and discussed in order to avoid confusion in using the term "farm operator" as defined in two different sec- 
tions of our country, where labour conditions are radically different.

It is to the advantage of operators in the South to keep the labourers and share-tenants satisfied, so that they will stay on the farms and be available to render such services as are needed. The best way to secure this condition is to give the labourer a chance to take some responsibility and share in the profits of the farm, giving him an opportunity to rise above the stage of a regular labourer, and to become owner of property.

The Labour Problem on the Farm.-There is general complaint among farmers that labour is scarce and inefficient. In many instances the complaint is justified; in others it is simply an excuse for inefficiency in ability to organise and direct labour-forces properly. Often those who employ people to work for them follow the principle of paying as small wages as possible, yet think themselves unfairly treated if the quantity of work is not up to standard.

Labour cannot be satisfactorily employed unless it is done on the basis of justice. The employer of labour should know what a standard 
day's work in all farm operations is. To require more of labourers is unjust, unless, in special circumstances, a given piece of work must be completed in order to prevent serious loss. The farmer who has demonstrated his intention to deal justly with men will, as a rule, find men willing to put in extra time in case of necessity. Labourers who do not show the right spirit in such circumstances should not be employed longer than is necessary.

Farm labourers often work inefficiently because their standard is low, and because they have not been taught to use tools in an efficient way. For this reason the most successful farmers work with their men as much as possible, to set the standard, and to show them how the work may be done in the best way with least effort. The writer has in mind a farmer who doubled the efficiency of his labour-force in setting posts and laying drain-tile simply through demonstrating, by means of his own labour, that a given amount of work could be done with less muscular effort in half the time they were accustomed to use. When these men were able to achieve the same results he raised their wages. 
In some cases inefficiency in working is due to improper nourishment. When farm labourers are given their board in addition to wages, the employer is treating them unjustly and unwisely from the standpoint of his own interests if he does not provide nourishing and rell-cooked food. He also is not doing his duty if he is not solicitous for their comfort and welfare in other ways.

So far as the writer knows no attempt has been made to measure the advantages derived from the just and humane treatment of farm labourers, but experience and observation on many farms in various localities has convinced him that the farmers applying the principles stated have little difficulty in solving labourproblems. They rarely complain of the scarcity of labour or of its inefficiency.

The man who works for wages wants his pay promptly and almost always frequently. The employer who can pay his hands in cash promptly, and when they want it, will find his ability to command labour greatly increased.

Extra Labour.-Many types of farming require a large amount of labour at certain seasons of 


\section{FARM ADMINISTRATION}

the year while at other seasons the amount required is very small. The labour required for short periods is, in most types of farming, regarded as extra labour. In the type of farming most common in the United States extra labour may be required in haying, wheat-harvesting, threshing, and corn-harvesting. Corn-husking, however, in most localities, can be extended over a comparatively long period of time, so that on the smaller farms extra labour may be dispensed with. Where it is customary to cut the corn and put it in shock, the cutting period is short, and the work is mostly done by hand, so that much extra labour is required. Where wheat raising is a large and important farm enterprise the employment of extra labour is an important and often serious problem. The fact, however, that the ripening of crops varies with latitude and altitude and the fact that most important crops are distributed over a large geographical area causes the labour for harvesting such crops to be distributed over a long period of time. Thus wheat harvesting, which begins in southern Texas about June, lasts until September 1 in the region of Montana and North 


\section{FARM MANAGEMENT}

Dakota. This enables a force of wheat harvesters to utilise a large part of the growing season by moving north and into higher altitudes as the ripening of grain proceeds. Cotton and tobacco are not distributed over such a large geographical area so that the harvesting of these crops must be done largely by local labour.

Standard Wages.-Where corn is cut, put in shock and husked, the work is commonly paid for by the shock, or the husking may often be paid for by the bushel. Thus, in a certain locality the average price paid for cutting corn, 16 hills square, is $121 / 2$ cents per shock, and 3 cents per bushel for husking. In the corn-belt husking and putting corn in the crib is usually done for 3 cents to 5 cents per bushel. In a district where Irish potatoes is the principal crop, picking, grading, and putting the potatoes in the barrel ready to load on a wagon, is done for 8 cents to 15 cents per barrel of 11 pecks, the rate any year depending on the yield of the crop. In 1913 the prices averaged about 10 cents a barrel for potatoes yielding approximately 40 barrels an acre. 
Such an operation as picking and packing strawberries for the market is paid for at standard rates per unit of work accomplished. Thus, in a well known strawberry region these rates were in 1913:

Picking

Packing

Nailing

Market Association Costs

42

2 cents per crate

5.5

Large numbers of pickers have to be employed to do the work when demanded. Men who look up and hire the pickers were paid 50 cents for each picker employed.

In localities where some crop such as wheat is the main enterprise-a crop that requires attention only during short seasons in the yearstandard prices develop for doing all the operations.

In one such locality the prices for raising the crop were in 1904-06:

Ploughing

Disking

Harrowing

$\$ 1.50$ per acre

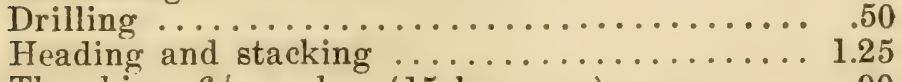

Threshing, $6 \phi$ per bu. (15 bu. crop) $\ldots . \ldots \ldots . .90$

Hauling 10 miles, $5 \phi$ per mile ( 15 bu. crop) ... .75 " "

Total Labour Cost

$\$ 5.55$ " "

These standard prices will vary from year to 
year in the same locality, and will be different for different localities.

Relations with a Bank.-Many farmers are at a great disadvantage in operating the farm because of lack of ready money, or the ability to get it promptly on reasonable terms and in proper amounts. The business man who is receiving and paying out money constantly finds the bank a most essential institution for service. The bank finds such a customer profitable and reliable, because, by watching his daily balances, he keeps in touch with the man's operations, knows when his credit is weak, and when strong. As a rule, in general farming, there are not more than one or two seasons in the year when the farmer deposits money in the bank. During the long intervals between, the banker is not much in touch with the farmer's business. He does not know how well he is operating his farm, caring for his stock, or investing his money. For this reason it is more difficult for the average farmer to establish credit with banks than it is for the average business man.

The operator of a farm may overcome this difficulty to a large extent by organising and 
operating his farm according to standard and reliable methods, and by cultivating a confidential relationship with some reliable banker. In this way the banker may become a useful and safe adviser, besides being ready to furnish credit when needed.

In some localities it may be wise for farmers to form associations for the purpose of strengthening individual credit.

The average amount of cash necessary to be kept on hand, or be accessible, varies much with the size of the farm business and with the type of farming. Dairy farms, and the small family farms organised with about an equal amount of crop and stock enterprises, require less than do either large grain farms or large stock farms. The large grain farm or orchard requires a large amount of cash on hand to pay extra labour-bills for threshing, materials for packing, etc.

In general, diversified farming reduces the amount of cash that must be kept on hand or made accessible. When such single enterprises as orcharding are depended on there may be periods of one, two, or three years, when there 
is little if any income; yet the operations must go on with the same detail and care if the enterprise is to be profitable through a series of years.

"Cheap" Farms.-Many persons, especially those who know but little about the details of farming, and who have not been trained to calculate the costs of building up land and maintaining fertility, are likely to be misled and disappointed in buying cheap farms. When farms were cheap only because of inaccessibility to market and general pioneer conditions, and when the movement of population toward this unoccupied land was constant and rapid, the buying of cheap lands was profitable. Under modern conditions, however, the ordinary "cheap" farm is about as profitable to buy as a worn out automobile. A person with a mechanical turn of mind might fix up and operate such an automobile successfully, and it might prove to be a very profitable investment. So it might be with a cheap farm, provided the operator knew exactly why it was cheap, and could make it valuable by expert ability. The 
average person who wishes to change his occupation to become a farmer would run much less risk in attempting to farm in a prosperous and well-developed neighbourhood. A successful business man, who had made a fortune in lumbering, and who knew the value of timber on any piece of land, casually remarked that he knew practically nothing about the relative merits of such and such situations for farming, but that he knew enough not to buy a piece of land with the intention of farming it when the present owner had let it alone.

First-class farmers will buy or rent only firstclass farms, for the same reason that a first-class workman will work only with first-class tools.

It is also true that the owner of a first-class farm wants to rent only to the first-class farmer. Any one, then, who wishes to follow the occupation of farmer should, besides studying the literature of the business, find an opportunity to work on a first-class farm under an operator or manager who knows his business. In this way a man who is strong physically, and alert in mind, may quickly learn to operate a good farm. 
Women as Managers.-Women may become efficient farm managers. Out of a list of selected farmers in a rather unfavourable agricultural district the only operator found making a labour-income above $\$ 500$ was a woman. If attention were given to the matter it would in all probability be found that women played a large and important part in the efficient management of farms, even if nominally the husband may be considered the operator and the labour-income be credited to him. This is true of many business occupations besides farming. Successful banking, merchandising, and even political success, are known in many cases to be owing largely to the wife of the household. It is more likely to be the case in farming, however, because the home stands in a relation to the general farm organisation that is not evident in other businesses.

As a rule neither the wife nor the other members of the family of a doctor, a lawyer, a banker or a blacksmith could give even approximately an intelligent record of the father's business for a year. In the case of farming, however, the writer has, in several cases, taken a 
good record of the farm business from the mother, or from the sons and daughters of the family.

The farm is well known to be an excellent place to train children in habits of work, and in responsibility. Many farmers, however, do not take full advantage of this opportunity. The average adult man or woman regard their children as dependents until they attain a specified age, say eighteen or twenty-one years old, then launch them on the world's business without having trained them to assume responsibility for the achievement of any definite project, or to follow skilfully a definite occupation.

It is encouraging to find some farmers who have discovered how to include the home in the plan of farm organisation, and to realise the opportunities in interesting and training the children in the responsibility and art of management.

This is the point where effective co-operation will begin. Members of a family who are made responsible for the successful management of certain enterprises or departments on the farm quickly develop an interest in their work, and 
under proper direction will make the farm organisation more efficient.

Among the difficult problems of land-tenure is the disposal of the farm business to those who may lawfully inherit it. In many cases the farm is sufficiently large in area, and opportunities are such, that two or three members of a family may jointly operate it, by dividing responsibility as suggested. In one case a 380-acre farm is being successfully operated by three brothers and a brother-in-law in joint ownership. One runs successfully a poultry department, another the dairy, the third a commercial orchard, while the fourth serves as the general superintendent.

In another case a medium-sized farm is being operated under three departments: an orchard department superintended by the father, a large and successful poultry plant by one son, while the general farming operations are being managed by another. 


\section{CHAPTER XI}

\section{THE STATE AND THE FARM}

ALL civilised nations today realise the importance of stimulating agricultural progress. Not only is the home population to be fed by the farmers, but modern nations regard it as proper and wise to seek markets abroad for farm products, for in this way resources develop rapidly, population grows, wealth increases, and the nation rises in relative power and prestige. So agriculture, being of vital importance in supporting the life of a people, and in making the nation rich and powerful, is naturally first among industrial enterprises to receive proper consideration from the State.

Training in Agriculture.-In our own country we have, besides the Federal Department of Agriculture, agricultural colleges and experiment stations in each State. These agencies working: together have developed into one of the greatest institutions in the world for the attainment and dissemination of agricultural knowledge. Indirectly they are also important agencies for the 
promotion of general scientific research, since the working out of technical problems in agriculture necessitates advancement in the physical sciences. Agricultural colleges have gained a notable prominence lately among educational institutions, and agricultural courses are getting a strong foothold in the high schools and in the rural schools. This widespread and growing interest in agricultural education indicates that the farm is recognised as holding a vital relation to the welfare of the nation; indeed, more than half our population live on farms, and make their living by raising the materials to feed and clothe the rest. Outside of cotton and wheat, only a very small amount of farm products is exported.

In spite of this increasing interest in agricultural training, one of the most important problems now engaging the attention of the United States Department of Agriculture and the State agricultural colleges is a more direct and vital contact between the scientific workshop and the farm. Successful manufacturing plants customarily engage experts to work out the technical problems involved in their business, and 


\section{THE STATE AND THE FARM 235}

to plan a better organisation to distribute and market their products. Such institutions are working for greater efficiency along all lines. New ideas are generally welcomed; they are tested, however, before being established in practice. It is perfectly logical and in line with efficiency that the federal and state agencies of scientific agriculture should develop a similar relation with the farm. Until recently the principal agencies that have been used to carry the results of scientific research and experiment to the farm have been farmers' institutes, the agricultural papers, and the Bulletins issued by the Government and Agricultural Colleges. Indirectly, of course, county newspapers and city daily papers are important agencies for the spread of such knowledge, for they print information interesting to general readers and of practical value to farmers. ${ }^{1}$

1 B. P. I. Circular No. 117, U. S. Department of Agriculture. "The Relation of Agricultural Extension Agencies and Farm Practice," C. Beaman Smith and H. K. Atwood. This report showed that the greatest direct influence was through the agricultural papers. Sixty-five per cent. of the farmers took farm papers. About thirty per cent. attended farmers' institutes and about one-half of this number made use of the suggestions made. 
The Farm Demonstration Work.-Within the last ten years a most important and successful agency has developed for carrying directly to the farm the results of agricultural investigations. This agency is known as the farm-demonstrator or county agent, who is employed by, and works co-operatively with, the Department of Agriculture and the state agricultural colleges. The fundamental idea underlying this work is that "all farmers of a commonwealth are properly students of the state agricultural college."

In 1904, Dr. Seaman A. Knapp, a special agent of the U. S. Department of Agriculture, started the Farmers' Co-operative Demonstration Work in the Southern States, where cottonfarms were being ravaged by the boll-weevil. The principal aim of Dr. Knapp was to exhibit on the farm in these States better methods of working cotton, so that higher yields could be made, and to introduce other crops adapted to the South which would give more diversity and hence result in greater profits and more reliable incomes. The county agent or demonstrator was the local representative of the Department, 


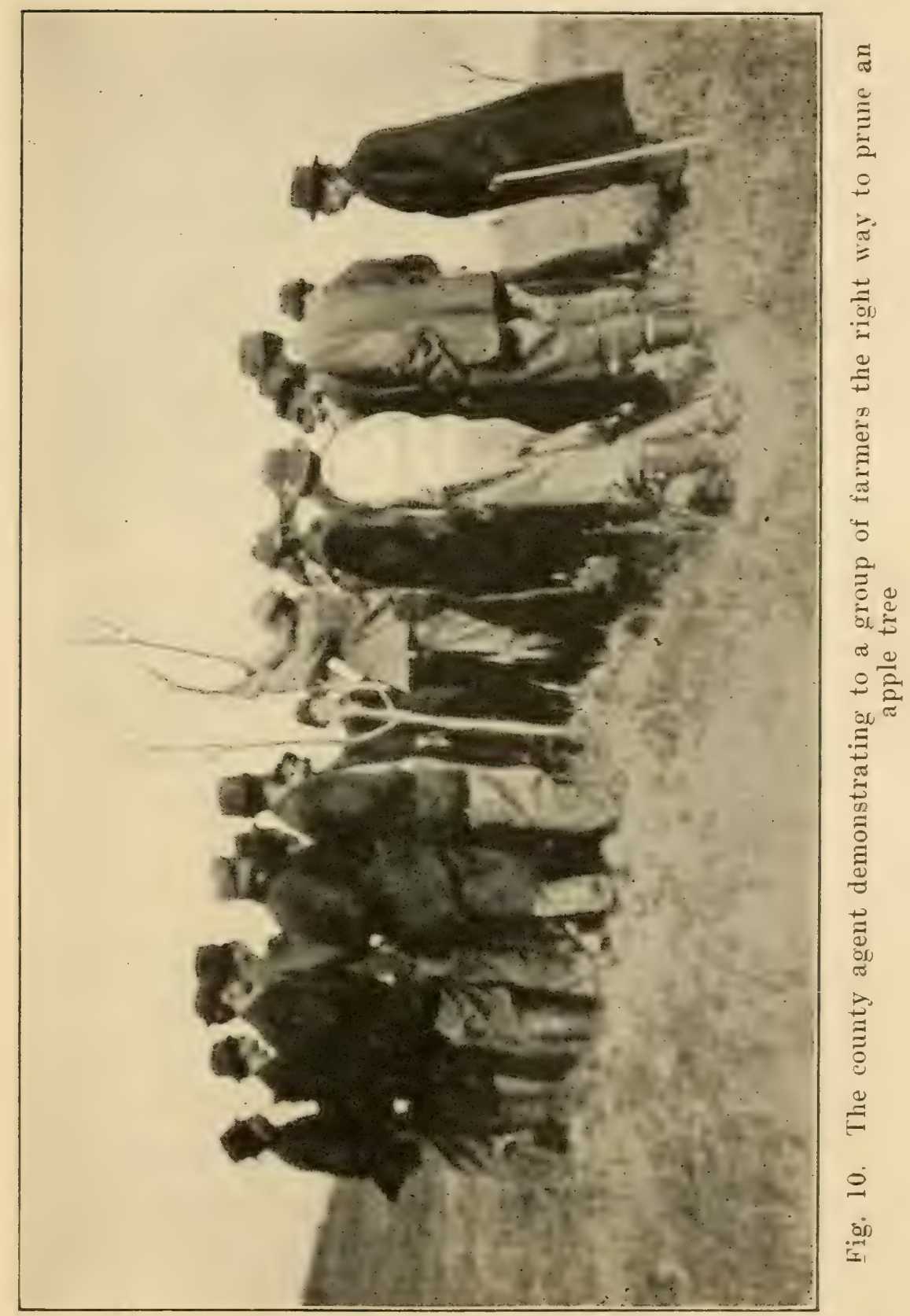





\section{THE STATE AND THE FARM 237}

who secured the agreement of a group of interested farmers to make a demonstration of a certain farm-practice or of a specific crop on their farms. This work had to be done strictly in accordance with the best and most practical knowledge to be had from the state experiment stations and the U. S. Department of Agriculture.

This plan proved so successful in the Cotton States, and became so widely known, that similar work is being developed in all parts of the United States. Demonstration-work in the North through county agents originated with the Office of Farm Management of the United States Department of Agriculture, and was carried on as a rule in co-operation with state agricultural colleges, as is now done everywhere.

Within the States the work is supervised by a man known as the State Leader, who is responsible to the extension department of the college, and also acts for the Department of Agriculture. The county agents are joint representatives of the Department and of the state colleges, and also are in a real sense the representatives of the 
farmers of the county, who share in the expenses of the work.

It is only in counties where farmers show a real interest and a desire to support this work that county agents are appointed. In some places farmers and business men have formed an association known as a "Farm Bureau," which has proved very effective in bringing about co-operative effort among farmers, and in many other ways increasing the efficiency of the county agent's work.

The demonstration work applies not only to the practice of adult farmers, but it includes also what is known as "club work," in which thousands of boys and girls are enrolled. This work aims at establishing better agriculture and better home economics through the young people. It teaches habits of industry and thrift, and co-operates with the public schools in supplementing text-book work with practical achievements.

Statistics.-In the Southern States, the 1914 report lists 33,276 farms on which demonstrations were made and 58,190 co-operators, farmers in some manner connected with the work. 


\section{THE STATE AND THE FARM 239}

There were 40,015 boys and 28,503 girls enrolled in clubs. On the demonstration farms the average yield of cotton was nearly doubled, and the increased yield of corn was about 16 bushels an acre.

A recent report by C. Beaman Smith, agriculturist in charge of farm demonstrations in the Northern and Western States, shows that during the year 1915, 365 county agents visited 192,230 farms, and 79,756 farm-bureaus were organised. The planning of 253 drainage systems was reported; 171 agents reported demonstrations on 241,479 acres of corn; 56 of these reported a yield above the average of 13 bushels per acre; and similar work was done on wheat, oats, potatoes, and other crops with marked increase in yields. These agents are helping the farmers to save a large amount of wealth by combating diseases among livestock. Eighty-one agents vaccinated 88,680 hogs, and farmers and veterinarians vaccinated 203,384 more, the larger part of which would have died if this treatment had not been given. Ninety farmers' exchanges and 164 purchasing and marketing associations were organised through 


\section{FARM MANAGEMENT}

the agents. The farmers' exchanges did a business valued at $\$ 327,610$. No less than 29,225 farms were supplied with labourers, and the number of labourers securing work through the exchanges was 5,488. The value of all business done through these agents in 1915 was $\$ 3,575$,373 and the approximate saving to farmers, $\$ 277,775$. This shows the nature of the work of the county agent in all parts of the United States, but it is best known in the South, where it first began and has been longest in operation.

Demonstrating Farm Business.-A new line of work taken up by the demonstrators in the northern part of the United States is that of making an analysis of the business of farming. This enables a farmer, with the assistance of the agent, to discover where wastes occur in his organisation. The main factors in successful farming in the community are carefully analysed, giving a standard of comparison by which these factors on any individual farm may be measured. During the year 1914-15 more than 10,500 farms were analysed in this way.

Educational Stimulus.-The county agents have had great influence in local educational work, di- 


\section{THE STATE AND THE FARM 241}

recting it especially to agricultural problems. This has been done not only through the boys' and girls' clubs but through the school organisation of the county. In one year 4614 schools were induced to include more agriculture in their courses, 3988 farmers were induced to attend short courses in a college of agriculture, and about 68,000 attended local short courses held by the agents. A nation-wide scope has been given to the work of organising this movement through the passage by Congress in 1914 of the Smith-Lever bill, under the provisions of which the Federal Government and the state governments co-operate in carrying on extension work in agriculture and home economics through county agents and specialists. Under the provisions of the Smith-Lever Act each State receives $\$ 10,000$ outright for this work from Federal sources. This appropriation is increased annually by the Government at the rate of about a half million dollars a year until at the end of eight years the total appropriation will reach $\$ 4,100,000$. This additional amount is distributed to the States according to the proportion which the rural population of the State 
bears to the total rural population of all the States. The State must raise a like amount each year to meet the additional appropriation. The final amount made available for county agent and other forms of extension work by this Act is $\$ 8,680,000$. In county agent work the State and Government usually contribute not to exceed $\$ 1200$ per county; the county through local taxation and otherwise contributing the remainder.

In addition to the increased prosperity and satisfaction which ought to come to the individual farmer and to his family from this movement, there should develop a stronger community purpose and ideal leading to a realisation that each person and family are parts of a great national unit.

\section{BOOKS ON FARM MANAGEMENT OR ON RELATED SUBJECTS}

American Farm Management Association. Record of the proceedings of annual meeting, 4th, 1913; 5th, 1914. [Washington, D. C.] 1914. 1915.

Bogart, Ernest LudLow. Economic history of the United States. 2d ed. Now York [etc.], Longmans, Green and Co. 1914.

Boss, ANdrew. Farm management. Chicago, New York, Lyons \& Carnahan. 1914. 


\section{THE STATE AND THE FARM 243}

CARD, Fred W. Farm management. New York, Doubleday, Page \& Co. 1907.

Carver, Thomas Nixon. Principles of rural economics. Boston [ete.], Ginn and Co. 1911.

CARver, Thomas Nixon, compiler. Selected reading in rural economics. Boston [etc.], Ginn and Co. 1916.

Cato, M. P., and Varro, M. T. Roman farm management, the treatises of Cato and Varro, done into English, with notes of modern instances. By a Virginia farmer. New York, Macmillan Co. 1913.

HAYs, W. M. Farm development. New York, London, Orange Judd Co. 1910.

Hunt, Thomas F. The young farmer; some things he should know. New York, Orange Judd Co. 1912.

Taylor, Henry C. An introduction to the study of agricultural economics. New York, London, Macmillan Co. 1914.

Warren, G. F. Farm management. New York, Macmillan Co. 1914.

WARren, G. F., and Livermore, K. C. Laboratory exercises in farm management. New York, Macmillan Co. 1910.

\section{THE END}

Printed in the United States of America. 

THE following pages contain advertisements of a few of the Macmillan books on kindred subjects. 



\section{The Farmer and the New Day}

BY KENYON L. BUTTERFIELD

President Massachusetts Agricultural College

Cloth, I2mo, $\$ 2.00$

Dr. Butterfield is dealing with the problems which confront the farmer to-day, not merely in their local, or even in their national significance, but rather with the world phases of the question. It is his purpose to formulate as concrete an agricultural program as possible. The need of a rural policy and the necessity for education and organization are two points which he emphasizes. The book is one to appeal to agricultural leaders, rural organizers and educators and members of grange farm bureaus particularly, as well as to all who make their living from the soil.

\section{The Little Town:}

Especially in Its Rural Relationships

By HARLAN PAUL DOUGLASS

Secretary American Missionary Association, Author of "The New Home Missions," etc.

Ill., Cloth, I2mo. $\$ 1.50$

Here we have a study of the little town, its relationships and prospects, its people, its possibilities and its ideals.

The book has grown out of the author's interest in rural progress. It is an effort to formulate a program which shall result in the realization on the part of the little town of some of its tremendous opportunities.

\section{Three Acres and Liberty}

\section{By BOLTON HALL}

Revised Edition, Ill., Cloth, I2mo, \$I.75

" 'Three Acres and Liberty' is no collection of fairy tales of the fortunes to be had by buying a hundred chickens or by cultivating tropical fruit. The author piles facts upon authenticated instance and successful experiment upon proved example, until there is no doubt about what can be done with land intensively treated. He shows also where the land may be found, what kind of land we must have, what it will cost and what to do with it." - New York Times.

\section{THE MACMILLAN COMPANY}




\title{
Farm Management
}

\author{
BY G. F. WARREN \\ (Rural Textbook Series)
}

Illustrated. I2mo, $\$ 1.75$

This book teaches the necessity of efficient farm organization and management so as to secure the farmer the best crops at the lowest price. Professor Warren shows the way to such efficiency and thoroughly discusses the more important phases of farm management from the selection and purchase of the farm to the marketing of its products.

\section{The Nursery Manual}

\section{By L. H. BAILEY \\ With Illustrations}

Cloth, I2mo. Professor Bailey's Nursery Book is the foundation of this volume, though the original has been entirely re-written and re-illustrated and appears now in The Rural Manual Series.

The book may be described as a complete guide to the multiplication of plants, aiming to give an account of the methods commonly employed in the propagation and crossing of plants.

The handling and sowing of seeds and spores, separation and division, layerage, the general requirements of cuttings and the various kinds, grafting, budding, nursery management - these are some of the topics taken up.

The illustrations are all from new drawings and photographs.

\section{Manual of American Grape Growing}

By U. P. HEDRICK

Horticulturist of the State Experiment Station, Geneva, N. Y. With Illustrations

Cloth, I2mo.

This is written as a complete popular treatise on grape-growing in North America. It discusses the practical questions of climatic limitations, choice of site, land and its preparation, fertilizing, tillage, planting, pruning and training, and marketing. It also has concise treatment of the diseases and the insects injurious to the grape. Special attention is given to descriptions of the leading commercial and amateur varicties. Part of the book is devoted to the vinifera grape as grown in California.

Professor Hedrick has had long experience in the study of the grape in all its aspects, and the book will be found to be a useful, up-to-date manual of propagation, manipulation, and the handling of the crop. It is well illustrated by full-page plates and also by engravings in the text.

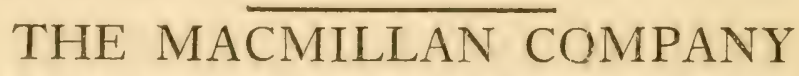




\title{
The Sugar-Beet in America
}

\author{
BY F. S. HARRIS
}

Director of the Utah Experiment Station

\section{Illustrated, $I 2^{\circ}, \$ 2.25$}

Here is a thorough and practical guide book for farmers who are raising sugar-beets, for agriculturists in sugar companies, and for students of the sugar-beet in agricultural colleges.

Dr. Harris has assembled here all the important facts and details regarding the raising and cultivation of the sugarbeet. There is also an account of the processes involved in the manufacturing of sugar from the beet, and a discussion of the sugar-beet's commercial rival, cane sugar.

A special feature of the book is the large number of illustrations - over 32 plates, with maps, diagrams and charts - clarifying the text and adding much to the practical value of the book.

\section{Peach-Growing}

\section{By H. P. GOULD}

Pomologist in Charge of Fruit Production Investigations Bureau of Plant Industry, U. S. Department of Agriculture

\section{Illustrated, $I 2^{\circ}, \$ 2.00$}

Here is a book which covers the general field of growing peaches and placing them within reach of the consumer.

It is practical. It is detailed. It is a handbook for peachgrowers of North and East, as well as South and West.

Peach literature has been notably limited, except for experiment station bulletins and reports. This book gathers into one compact, fully illustrated volume the principles and practice of successful peach production. 


\section{TWO STANDARD CYCLOPEDIAS}

\section{Cyclopedia of American Agriculture}

EDITED By L. H. BAILEY

With roo full-page plates and more than 2,000 illustrations in the text; four volumes; the set, $\$ 20.00$

Vol. I-Farms

Vol. II-Crops
Vol. III-Animals

Vol. IV-The Farm and the Community

This is unquestionably the most important agricultural cyclopedic work published in this country. The leading experts in the United States and Canada, both investigators and practical farmers, contribute to its chapters, which are arranged not alphabetically, but topically, each subject being treated in its various aspects by men especially familiar with it.

"Indispensable to public and reference libraries ... readily comprehensible to any person of average education."-The Nation.

"The completest existing thesaurus of up-to-date facts and opinions on modern agricultural methods. It is safe to say that many years must pass before it can be surpassed in comprehensiveness, accuracy, practical value, and mechanical excellence. It ought to be in every library in the country."-Record-Herald, Chicago.

\section{The Standard Cyclopedia of Horticulture}

\section{Edited by L. H. BAILEY}

With the Assistance of over 500 Collaborators

Now complete in 6 vols. Set, cloth, $\$ 36.00$

"No one who knows anything at all about the literature of gardening needs to be told that the Cyclopedia is unique. It is the Bible and Britannica of the garden-folk, amateur and professional alike. And the remarkable thing is that while it is fundamentally a work of reference, it also contains limitless quantities of good reading of the sort dear to the heart of the garden enthusiast."-The Nation.

"It is no exaggeration to state that Bailey's new work is the best Cyclopedia obtainable for all who are connected, either remotely or intimately, as amateurs or professionals, with horticultural pursuits." - The Florists' Review.

\section{THE MACMILLAN COMPANY}

Publishers 64-66 Fifth Avenue New York 







\section{LIBRARY OF CONGRESS}

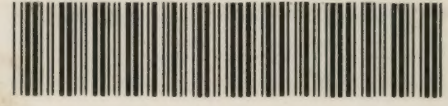

ด0027?81780 